Prepared in cooperation with the California State Water Resources Control Board A product of the California Groundwater Ambient Monitoring and Assessment (GAMA) Program

\title{
Updated Study Reporting Levels (SRLs) for Trace-Element Data Collected for the California Groundwater Ambient Monitoring and Assessment (GAMA) Priority Basin Project, October 2009-March 2013
}

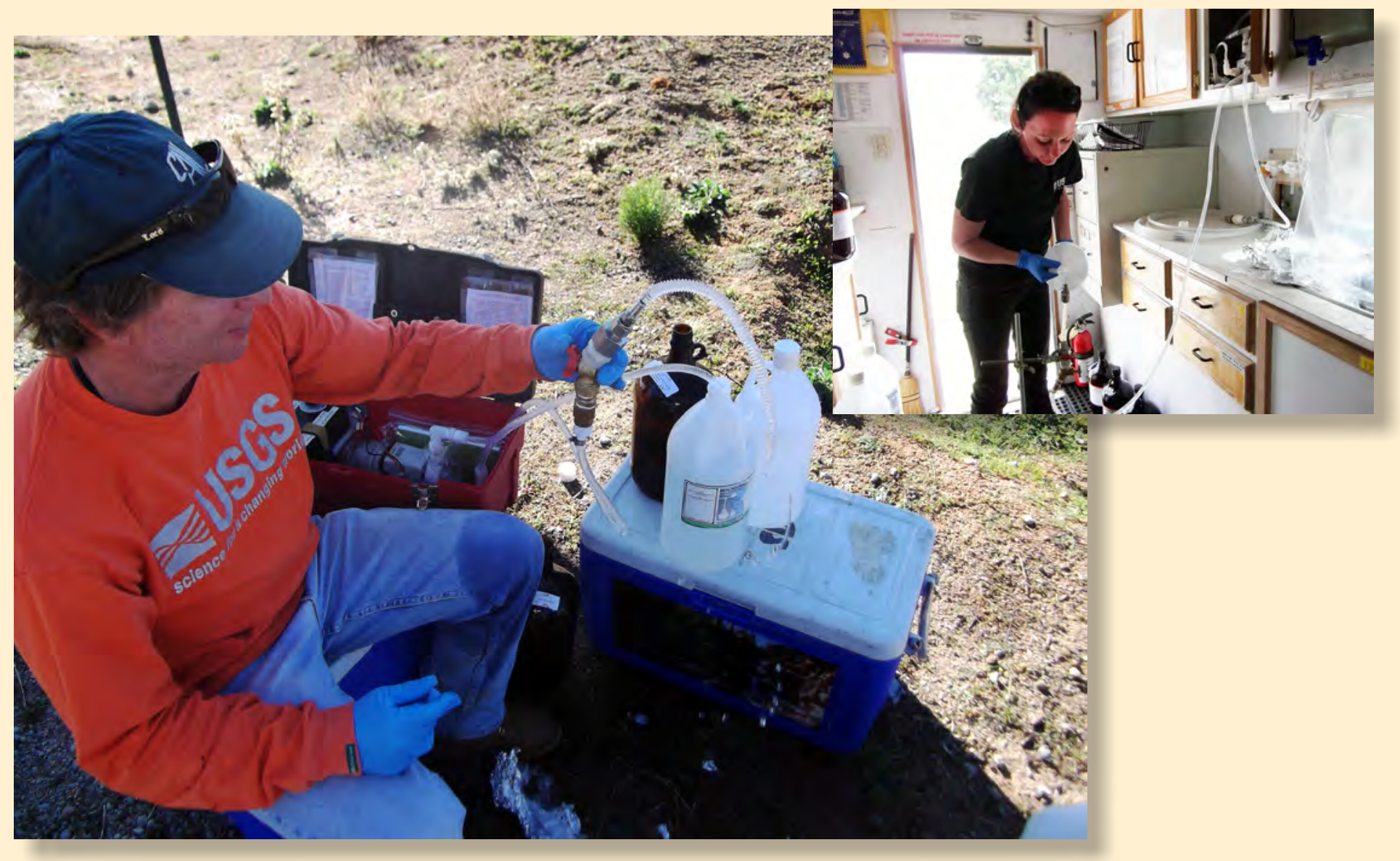

Scientific Investigations Report 2014-5105 


\section{Cover photographs:}

Left-Field crew member using a portable quality-control pump to rinse a short sampling line with inorganic blank water during the collection of a field blank at a well site. (Photograph by Franklin J. Moseanko, U.S. Geological Survey.)

Right-Field crew member using a quality-control pump to rinse a long sampling line with inorganic blank water during the collection of a field blank inside a mobile laboratory. (Photograph by Dara A. Goldrath, U.S. Geological Survey.) 


\section{Updated Study Reporting Levels (SRLs) for Trace-Element Data Collected for the California Groundwater Ambient Monitoring and Assessment (GAMA) Priority Basin Project, October 2009- March 2013}

By Tracy A. Davis, Lisa D. Olsen, Miranda S. Fram, and Kenneth Belitz

Prepared in cooperation with the California State Water Resources Control Board

Scientific Investigations Report 2014-5105 


\title{
U.S. Department of the Interior SALLY JEWELL, Secretary
}

\section{U.S. Geological Survey Suzette M. Kimball, Acting Director}

\author{
U.S. Geological Survey, Reston, Virginia: 2014
}

For more information on the USGS - the Federal source for science about the Earth, its natural and living resources, natural hazards, and the environment, visit http://www.usgs.gov or call 1-888-ASK-USGS.

For an overview of USGS information products, including maps, imagery, and publications, visit http://Www.usgs.gov/pubprod

To order this and other USGS information products, visit http://store.usgs.gov

Any use of trade, firm, or product names is for descriptive purposes only and does not imply endorsement by the U.S. Government.

Although this information product, for the most part, is in the public domain, it also may contain copyrighted materials as noted in the text. Permission to reproduce copyrighted items must be secured from the copyright owner.

Suggested citation:

Davis, T.A., Olsen, L.D., Fram, M.S., and Belitz, Kenneth, 2014, Updated study reporting levels (SRLs) for trace-element data collected for the California Groundwater Ambient Monitoring and Assessment (GAMA) Priority Basin Project, October 2009-March 2013: U.S. Geological Survey Scientific Investigations Report 2014-5105, 52 p.

http://dx.doi.org/10.3133/sir20145105.

ISBN 978-1-4113-3817-3

ISSN 2328-031X (print)

ISSN 2328-0328 (online) 


\section{Contents}

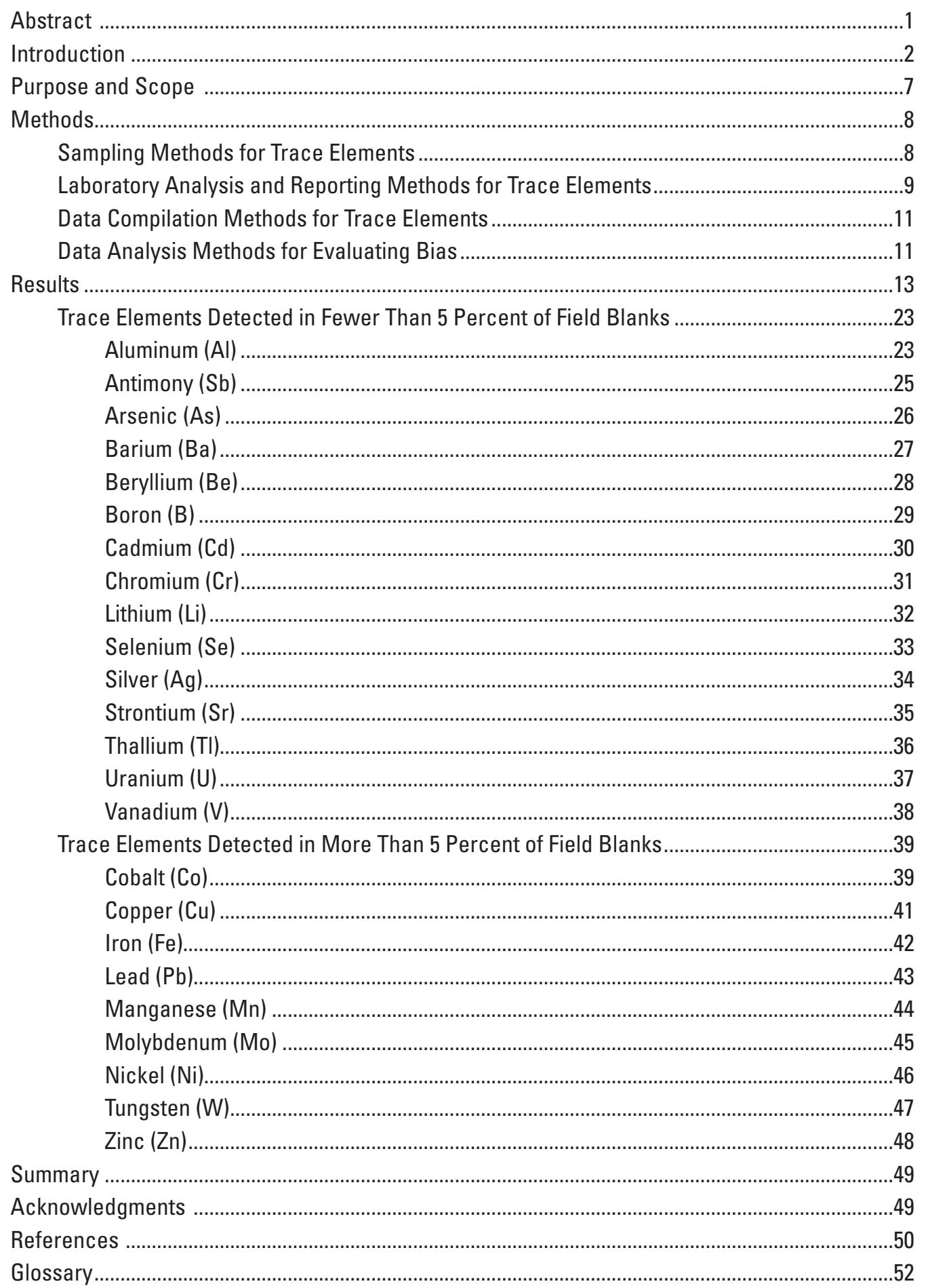




\section{Figures}

1. Map showing locations of study units and wells sampled for the GAMA Priority Basin Project, 2004-12.

2. Map showing hydrogeologic provinces, major cities, and locations of study units and wells sampled for the GAMA Priority Basin Project Shallow Aquifer

Assessment, 2012-13.

3. Graphs showing trace-element concentrations, study reporting levels, laboratory reporting levels, and long-term method detection levels for constituents detected in fewer than 5 percent of the field blanks collected from October 2009 through March 2013, GAMA Priority Basin Project: $(A)$ aluminum, $(B)$ antimony, $(C)$ arsenic, $(D)$ barium, $(E)$ beryllium, $(F)$ boron, $(G)$ cadmium, $(H)$ chromium, ( $/)$ lithium, $(J)$ selenium, $(K)$ silver, $(L)$ strontium, $(M)$ thallium, $(M)$ uranium, and $(O)$ vanadium .......24

4. Graph showing cobalt concentrations in field blanks and groundwater samples collected March 2006 through March 2013, plotted in time-series with the laboratory reporting levels, and long-term method detection levels, GAMA Priority Basin Project

5. Graph showing copper concentrations in field blanks collected March 2006 through March 2013, plotted in time-series with the study reporting levels, laboratory reporting levels, and long-term method detection levels, GAMA Priority Basin Project

6. Graph showing iron concentrations in field and source-solution blanks collected March 2006 through March 2013, plotted in time-series with the study reporting levels, laboratory reporting levels, and long-term method detection levels, GAMA Priority Basin Project

7. Graph showing lead concentrations in field and source-solution blanks collected March 2006 through March 2013, plotted in time-series with the study reporting levels, laboratory reporting levels, and long-term method detection levels, GAMA Priority Basin Project

8. Graph showing manganese concentrations in field blanks collected March 2006 through March 2013, plotted in time-series with the study reporting levels, laboratory reporting levels, and long-term method detection levels, GAMA Priority Basin Project

9. Graph showing molybdenum concentrations in field blanks collected March 2006 through March 2013, plotted in time-series with the study reporting levels, laboratory reporting levels, and long-term method detection levels, GAMA Priority Basin Project

10. Graph showing nickel concentrations in field and source-solution blanks collected March 2006 through March 2013, plotted in time-series with the study reporting levels, laboratory reporting levels, and long-term method detection levels, GAMA Priority Basin Project

11. Graph showing tungsten concentrations in field blanks collected March 2006 through March 2013, plotted in time-series with the study reporting levels, laboratory reporting levels, and long-term method detection levels, GAMA Priority Basin Project

12. Graph showing zinc concentrations in field blanks collected March 2006 through March 2013, plotted in time-series with the study reporting levels, laboratory reporting levels, and long-term method detection levels, GAMA Priority Basin Project 


\section{Tables}

1. Study unit names, Data Series reports, and sampling dates for the GAMA Priority Basin Project, 2004-13, and the NAWQA Program Southern California Coastal Drainages study unit, 2004-12, and number of the blanks included in this assessment for each study unit.

2. Trace elements collected for the USGS GAMA Priority Basin Project, reporting information for the USGS NWQL, and comparative benchmarks

3A. Detection frequencies for trace elements in field blanks collected for the USGS GAMA Priority Basin Project and the NAWQA Program Southern California Coastal Drainages study unit, March 2006-September 2009 and October 2009March 2013 .

3B. Detection frequencies for trace elements in the associated groundwater samples collected for the USGS GAMA Priority Basin Project and the NAWQA Program Southern California Coastal Drainages study unit, March 2006-September 2009 and October 2009-March 2013.

4. Summary of results for USGS NWOL laboratory blanks analyzed for trace elements, including mean concentrations and standard deviations, March 2006September 2009 and October 2009-March 2013.

5. Summary of LT-MDL calculations for water years 2010-13 by the USGS Branch of Quality Systems LT-MDL Project from blind blanks and internal laboratory blanks analyzed by the USGS National Water Quality Laboratory for trace elements

6. Summary of updated study reporting levels for trace-element data collected for the USGS GAMA Priority Basin Project, October 2009 through March 2013

\section{Conversion Factors}

\begin{tabular}{lcl}
\multicolumn{1}{c}{ Inch/Pound to SI } & \multicolumn{1}{c}{ Bultiply } & \multicolumn{1}{c}{ To obtain } \\
\hline & \multicolumn{1}{c}{ Length } \\
\hline inch (in.) & 2.54 & centimeter (cm) \\
inch (in.) & 25.4 & millimeter (mm) \\
foot (ft) & 0.3048 & meter (m) \\
mile (mi) & 1.609 & kilometer (km) \\
\hline \multicolumn{2}{c}{ Volume } \\
\hline ounce, fluid (fl. oz) & 0.02957 & liter (L) \\
pint (pt) & 0.4732 & liter (L) \\
quart (qt) & 0.9464 & liter (L) \\
\hline
\end{tabular}

Horizontal coordinate information is referenced to the North American Datum of 1983 (NAD 83).

Concentrations of chemical constituents in water are given in micrograms per liter ( $\mu \mathrm{g} / \mathrm{L})$. 


\section{Abbreviations and Acronyms}

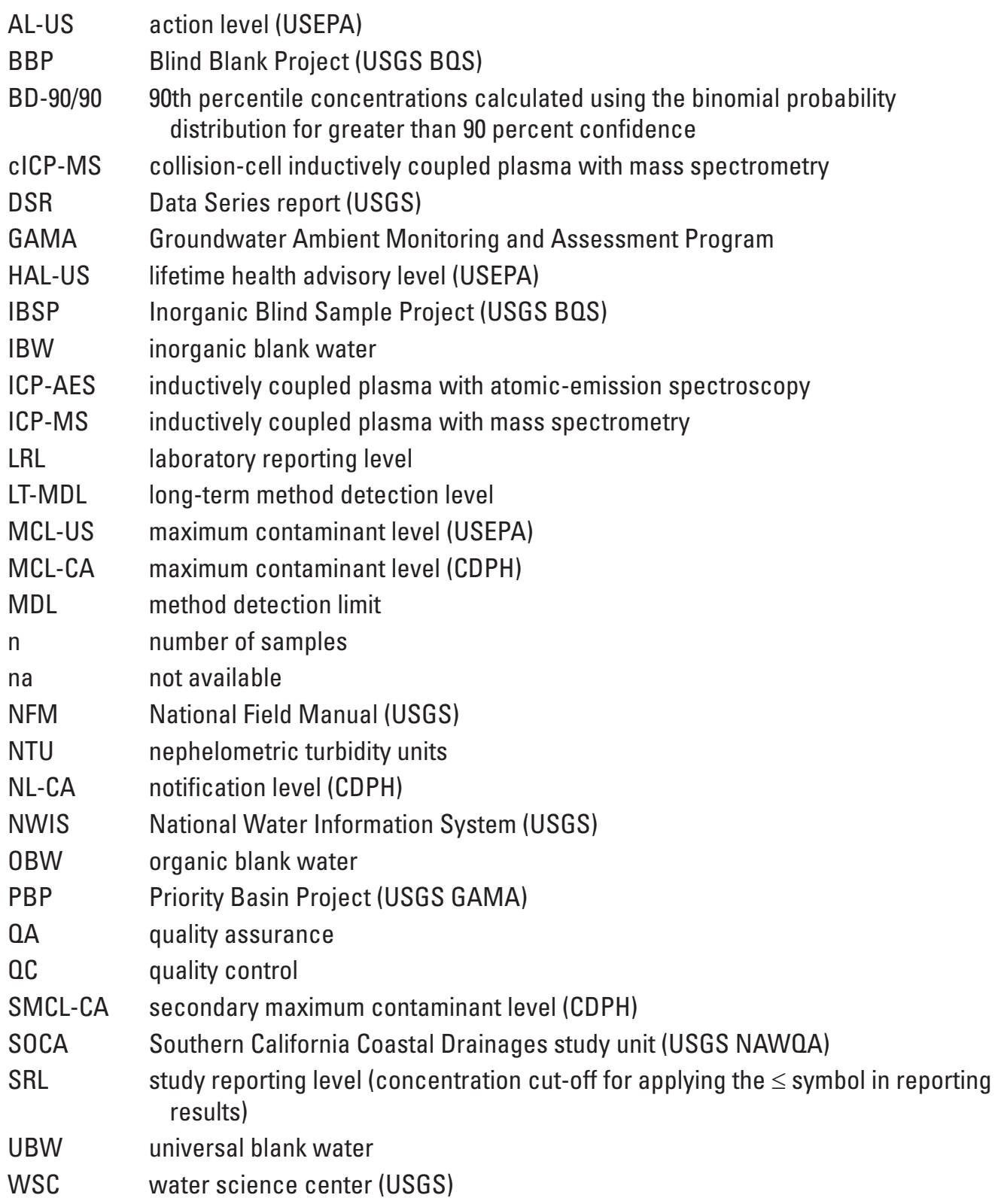




\section{Organizations}

$\begin{array}{ll}\text { BOS } & \text { Branch of Quality Systems (USGS) } \\ \text { CDPH } & \text { California Department of Public Health } \\ \text { CDWR } & \text { California Department of Water Resources } \\ \text { LLNL } & \text { Lawrence Livermore National Laboratory } \\ \text { NAWQA } & \text { National Water-Quality Assessment Program (USGS) } \\ \text { NELAP } & \text { National Environmental Laboratory Accreditation Program } \\ \text { NWQL } & \text { National Water Quality Laboratory (USGS) } \\ \text { SWRCB } & \text { California State Water Resources Control Board } \\ \text { USEPA } & \text { U.S. Environmental Protection Agency } \\ \text { USGS } & \text { U.S. Geological Survey }\end{array}$

\section{Units of Measure}

$\begin{array}{ll}\mathrm{L} & \text { liter } \\ \mathrm{mL} & \text { milliliter } \\ \mu \mathrm{g} / \mathrm{L} & \text { micrograms per liter (equivalent to parts per billion) } \\ \mu \mathrm{m} & \text { micrometer (micron) }\end{array}$

\section{Note}

This report contains Chemical Abstracts Service (CAS) Registry Numbers ${ }^{\circledR}$, which is a Registered Trademark of the American Chemical Society. CAS recommends the verification of the CAS Registry Numbers through CAS Client Services ${ }^{\mathrm{TM}}$. 


\title{
Updated Study Reporting Levels (SRLs) for Trace-Element Data Collected for the California Groundwater Ambient Monitoring and Assessment (GAMA) Priority Basin Project, October 2009-March 2013
}

\author{
By Tracy A. Davis, Lisa D. Olsen, Miranda S. Fram, and Kenneth Belitz
}

\section{Abstract}

Groundwater samples have been collected in California as part of statewide investigations of groundwater quality conducted by the U.S. Geological Survey for the Groundwater Ambient Monitoring and Assessment (GAMA) Priority Basin Project (PBP). The GAMA-PBP is being conducted in cooperation with the California State Water Resources Control Board to assess and monitor the quality of groundwater resources used for drinking-water supply and to improve public knowledge of groundwater quality in California. Quality-control samples (source-solution blanks, equipment blanks, and field blanks) were collected in order to ensure the quality of the groundwater sample results.

Olsen and others $(2010)^{1}$ previously determined study reporting levels (SRLs) for trace-element results based primarily on field blanks collected in California from May 2004 through January 2008. SRLs are raised reporting levels used to reduce the likelihood of reporting false detections attributable to contamination bias. The purpose of this report is to identify any changes in the frequency and concentrations of detections in field blanks since the last evaluation and update the SRLs for more recent data accordingly. Constituents analyzed were aluminum (Al), antimony ( $\mathrm{Sb}$ ), arsenic (As), barium (Ba), beryllium $(\mathrm{Be})$, boron $(\mathrm{B})$, cadmium $(\mathrm{Cd})$, chromium $(\mathrm{Cr})$, cobalt $(\mathrm{Co})$, copper $(\mathrm{Cu})$, iron $(\mathrm{Fe})$, lead $(\mathrm{Pb})$, lithium $(\mathrm{Li})$, manganese $(\mathrm{Mn})$, molybdenum (Mo), nickel (Ni), selenium (Se), silver (Ag), strontium (Sr), thallium (Tl), tungsten (W), uranium (U), vanadium $(\mathrm{V})$, and zinc $(\mathrm{Zn})$.

Data from 179 field blanks and equipment blanks collected from March 2006 through March 2013 by the GAMA-PBP indicated that for trace elements that had a

\footnotetext{
${ }^{1}$ Olsen, L.D., Fram, M.S., and Belitz, Kenneth, 2010, Review of traceelement field blank data collected for the California Groundwater Ambient Monitoring and Assessment (GAMA) Program, May 2004-January 2008: U.S. Geological Survey Scientific Investigations Report 2009-5220, 47 p. (Also available at http://pubs.usgs.gov/sir/2009/5220/.)
}

change in detection frequency and concentration since the previous review, the shift occurred near October 2009, in conjunction with a change in the capsule filters used by the study. Results for 89 field blanks and equipment blanks collected from October 2009 through March 2013 were evaluated for potential contamination bias by using the same approach developed by Olsen and others (2010). Some data collected by the National Water-Quality Assessment (NAWQA) Program for the Southern California Coastal Drainages study unit were included to supplement the GAMAPBP data. The detection frequency and upper threshold of potential contamination bias (BD-90/90) were determined from field-blank and equipment-blank data for each trace element. The BD-90/90 is the $90^{\text {th }}$ percentile concentration of potential extrinsic contamination calculated by using the binomial probability distribution for greater than 90 percent confidence. Additionally, data from laboratory blanks and blind blanks analyzed by the National Water Quality Laboratory (NWQL) during water years 2010 through 2013, and compiled by the USGS Branch of Quality Systems (BQS), were considered for each trace element. These results were compared to each constituent's reporting level to determine whether an SRL was necessary to minimize the potential for detections in the groundwater samples, attributed principally to contamination bias. Results of the evaluation were used to set SRLs for trace-element data for about 1,135 samples of groundwater collected by the GAMA-PBP between October 2009 and March 2013.

Ten trace elements analyzed ( $\mathrm{Sb}, \mathrm{As}, \mathrm{Be}, \mathrm{B}, \mathrm{Cd}, \mathrm{Li}$, Se, Ag, Tl, and U) had blank results that did not necessitate establishing SRLs during this review or the review by Olsen and others (2010). Five trace elements analyzed (Al, Ba, Cr, $\mathrm{Sr}$, and V) had blank results that necessitated establishing an SRL during the previous review but did not need an SRL starting October 2009. One trace element (Fe) had field and laboratory-blank results that necessitated keeping the previous SRL (6 micrograms per liter $[\mu \mathrm{g} / \mathrm{L}])$. Two trace elements $(\mathrm{Ni}$ and $\mathrm{W}$ ) had quality-control results that warranted decreasing the previous $\mathrm{SRL}$, and five trace elements $(\mathrm{Cu}, \mathrm{Pb}, \mathrm{Mn}$, 
Mo, and Zn) had field, laboratory, or blind blank results that warranted establishing an SRL for the first time or increasing the previous SRL. SRLs for $\mathrm{Cu}(2.1 \mu \mathrm{g} / \mathrm{L}), \mathrm{Pb}(0.82 \mu \mathrm{g} / \mathrm{L}), \mathrm{Mn}$ $(0.66 \mu \mathrm{g} / \mathrm{L})$, Mo $(0.023 \mu \mathrm{g} / \mathrm{L}), \mathrm{Ni}(0.21 \mu \mathrm{g} / \mathrm{L}), \mathrm{W}(0.023 \mu \mathrm{g} / \mathrm{L})$, and $\mathrm{Zn}(6.2 \mu \mathrm{g} / \mathrm{L})$ were changed to these levels starting October 2009, based on the BD-90/90 concentration for field blanks or the $99^{\text {th }}$ percentile concentration for laboratory or blind blanks. The SRL for Fe was maintained at $6 \mu \mathrm{g} / \mathrm{L}$, based on the minimum laboratory reporting level for iron. SRLs for these eight constituents were at least an order of magnitude below the regulatory benchmarks established for drinking water for health and aesthetic purposes; therefore, the practice of reporting concentrations below the SRLs as less than or equal to $(\leq)$ the measured value would not prevent the identification of values greater than the drinkingwater benchmarks. Co was detected in 99 percent of field blanks, and with a BD-90/90 concentration of $0.38 \mu \mathrm{g} / \mathrm{L}$, all groundwater results starting October 2009 were coded as "reviewed and rejected." Co does not currently have a regulatory benchmark for drinking water. The primary sources of contamination for trace elements inferred from this review are the equipment or processes used in the field to collect the samples or in the laboratory. In particular, contamination in field blanks of $\mathrm{Co}$ and $\mathrm{Mn}$ was attributed to the high-capacity 0.45 -micrometer pore-size capsule filters that were in regular use beginning in October 2009 by several USGS programs, including the GAMA-PBP and NAWQA Program, for filtering samples for analysis of trace elements.

The SRLs determined in this report are intended to be used for GAMA groundwater-quality data for samples collected October 2009 through March 2013, or for as long as quality-control data indicate contamination similar to what was observed in this report; quality-control data should be continuously reviewed and SRLs re-assessed on at least a study-unit basis.

\section{Introduction}

To assess the quality of ambient groundwater in aquifers used for drinking-water supply and to establish a baseline groundwater-quality monitoring program on a statewide scale, the California State Water Resources Control Board (SWRCB), in cooperation with the U.S. Geological Survey (USGS) and Lawrence Livermore National Laboratory (LLNL), implemented the Groundwater Ambient Monitoring and Assessment (GAMA) Program (http://www.waterboards. ca.gov/water_issues/programs/gama). The GAMA Program was developed in response to the Groundwater Quality Monitoring Act of 2001 (State of California, 2001a, 2001b, Sections 10780-10782.3 of the California Water Code, Assembly Bill 599) to assess and monitor the quality of groundwater in California. The statewide GAMA Program currently consists of four projects: (1) the GAMA Priority Basin Project (PBP), conducted by the USGS; (2) the GAMA Domestic Well Project, conducted by the SWRCB; (3) the GAMA Special Studies, conducted by LLNL; and (4) GeoTracker GAMA, conducted by the SWRCB. The GAMA-PBP relies extensively on previous work conducted by the USGS through the National Water-Quality Assessment (NAWQA) Program for the framework of status assessments (the assessment of the current groundwater resource), trends (the detection of changes in water quality), and understanding assessments (assessing the human and natural factors that affect groundwater quality). The GAMA-PBP applies uniform and consistent study-design and data-collection protocols across California (Belitz and others, 2003).

The initial phase of the GAMA-PBP focused on assessing groundwater resources used for public drinkingwater supplies. Selected groundwater basins defined by the California Department of Water Resources (CDWR) were grouped into 35 study units, and more than 2,000 wells were sampled between 2004 and 2012 (fig. 1). Most wells selected for the first phase of the GAMA-PBP were municipal and community drinking-water supply wells and are listed in the $\mathrm{CDPH}$ water-quality monitoring database (California Department of Public Health, 2013b). The second phase, known as the Shallow Aquifer Assessment, began in 2012 and is focused on assessing shallow groundwater resources. These shallow aquifers provide water for domestic and small community-supply wells, which are often drilled to shallower depths in the groundwater system than public-supply wells (U.S. Geological Survey, 2013); from 2012 to 2013, the USGS sampled 170 wells for this second phase (fig. 2). Most wells selected for the second phase of the GAMA-PBP, which started sampling in April 2012, were domestic. Some irrigation, industrial, and monitoring wells were also sampled for both phases. Reports published to date by the GAMA-PBP addressing the water-quality assessments of each study unit (table 1) are available from the USGS GAMA website http://ca.water.usgs.gov/gama. 


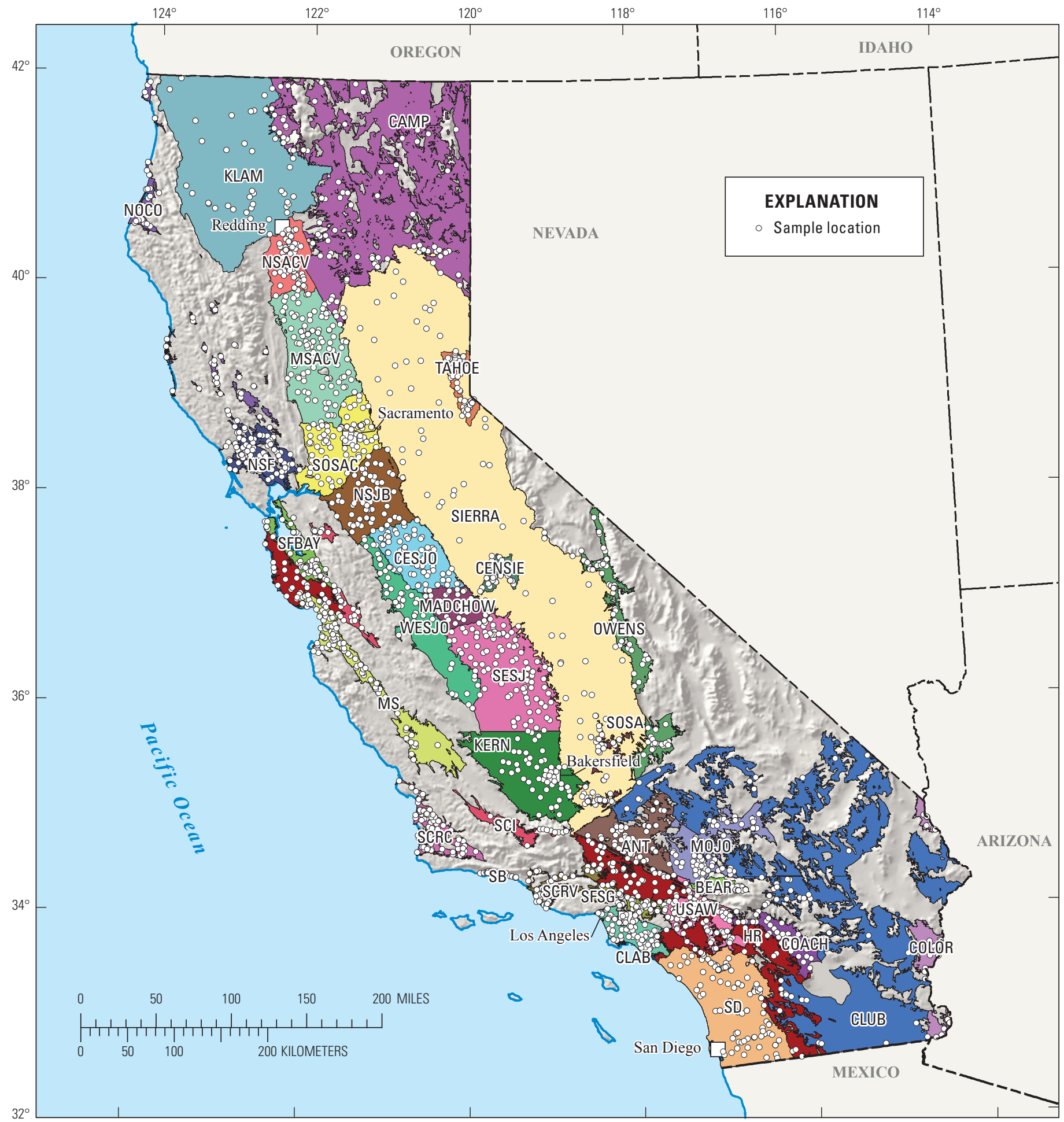

Shaded relief derived from U.S. Geological Survey National Elevation Dataset, 2006,

Albers Equal Area Conic Projection

See table 1 for more information about the study units.

Figure 1. Locations of study units and wells sampled for the Groundwater Ambient Monitoring and Assessment (GAMA) Priority Basin Project, 2004-12. 


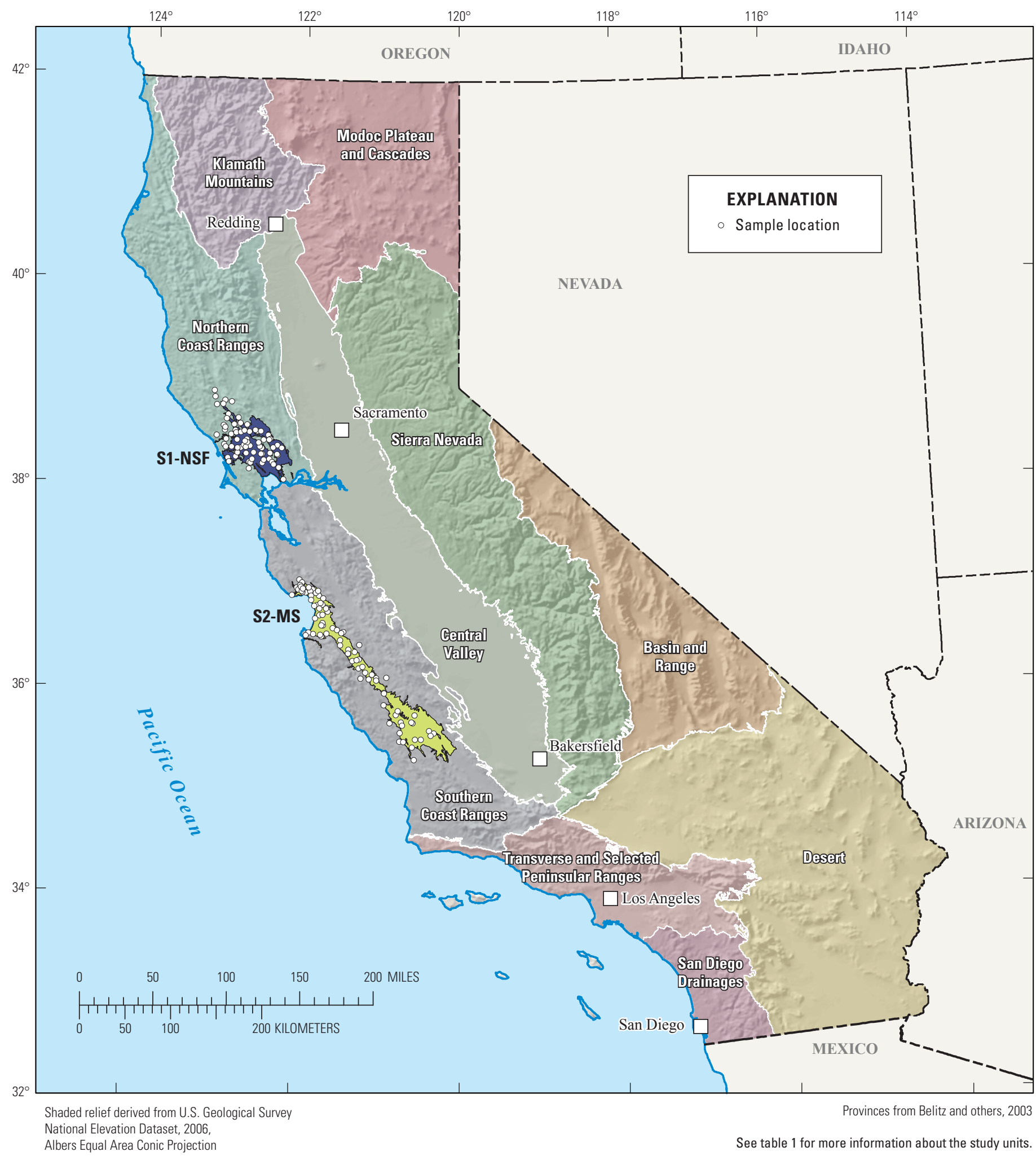

Figure 2. Hydrogeologic provinces, major cities, and locations of study units and wells sampled for the Groundwater Ambient Monitoring and Assessment (GAMA) Priority Basin Project Shallow Aquifer Assessment, 2012-13. 
Table 1. Study unit names, Data Series reports (DSRs), and sampling dates for the Groundwater Ambient Monitoring and Assessment (GAMA) Priority Basin Project, 2004-13, and the National Water-Quality Assessment (NAWQA) Program Southern California Coastal Drainages (SOCA) study unit, 2004-12, and number of the blanks included in this assessment for each study unit.

[DSRs and other reports published to date by the GAMA Priority Basin Project can be found online at http://ca.water.usgs.gov/projects/gama/includes/GAMA publications.html. Various reports published to date by the NAWQA Program pertaining to water-quality conditions on local, regional, and national scales can be found online at http://water.usgs.gov/nawqa/bib/. Abbreviations: na, not available]

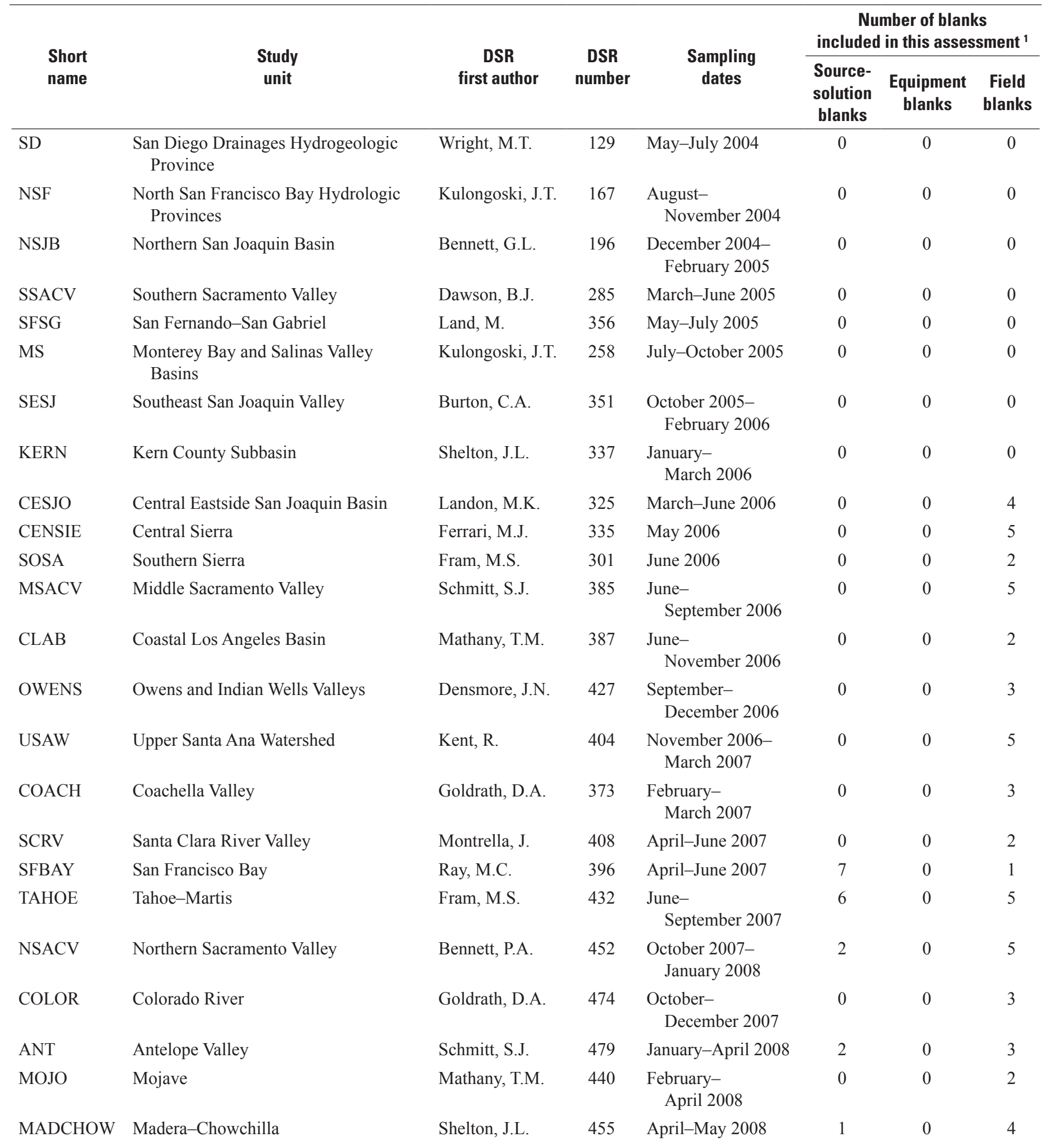


Table 1. Study unit names, Data Series reports (DSRs), and sampling dates for the Groundwater Ambient Monitoring and Assessment (GAMA) Priority Basin Project, 2004-13, and the National Water-Quality Assessment (NAWQA) Program Southern California Coastal Drainages (SOCA) study unit, 2004-12, and number of the blanks included in this assessment for each study unit.—Continued

[DSRs and other reports published to date by the GAMA Priority Basin Project can be found online at http://ca.water.usgs.gov/projects/gama/includes/GAMA publications.html. Various reports published to date by the NAWQA Program pertaining to water-quality conditions on local, regional, and national scales can be found online at http://water.usgs.gov/nawqa/bib/. Abbreviations: na, not available]

\begin{tabular}{|c|c|c|c|c|c|c|c|}
\hline \multirow{2}{*}{$\begin{array}{l}\text { Short } \\
\text { name }\end{array}$} & \multirow{2}{*}{$\begin{array}{l}\text { Study } \\
\text { unit }\end{array}$} & \multirow{2}{*}{$\begin{array}{l}\text { DSR } \\
\text { first author }\end{array}$} & \multirow{2}{*}{$\begin{array}{c}\text { DSR } \\
\text { number }\end{array}$} & \multirow{2}{*}{$\begin{array}{l}\text { Sampling } \\
\text { dates }\end{array}$} & \multicolumn{3}{|c|}{$\begin{array}{c}\text { Number of blanks } \\
\text { included in this assessment }{ }^{1}\end{array}$} \\
\hline & & & & & $\begin{array}{c}\text { Source- } \\
\text { solution } \\
\text { blanks }\end{array}$ & $\begin{array}{l}\text { Equipment } \\
\text { blanks }\end{array}$ & $\begin{array}{l}\text { Field } \\
\text { blanks }\end{array}$ \\
\hline $\mathrm{SCRC}$ & South Coast Range-Coastal & Mathany, T.M. & 504 & $\begin{array}{l}\text { May- } \\
\text { December } 2008\end{array}$ & 3 & 0 & 3 \\
\hline $\mathrm{SCI}$ & South Coast Interior Basins & Mathany, T.M. & 463 & $\begin{array}{l}\text { August- } \\
\quad \text { December } 2008\end{array}$ & 0 & 0 & 5 \\
\hline CLUB & $\begin{array}{l}\text { Borrego Valley, Central Desert, and } \\
\text { Low-Use Basins }\end{array}$ & Mathany, T.M. & 659 & $\begin{array}{l}\text { December 2008- } \\
\text { March } 2010\end{array}$ & 0 & 0 & 5 \\
\hline WESJO & Western San Joaquin Valley & Mathany, T.M. & 706 & March-July 2010 & 2 & 0 & 6 \\
\hline CAMP & Cascade Range and Modoc Plateau & Shelton, J.L. & 688 & July-October 2010 & 1 & 0 & 10 \\
\hline KLAM & Klamath Mountains & Mathany, T.M. & 803 & $\begin{array}{l}\text { October- } \\
\text { December } 2010\end{array}$ & 0 & 0 & 5 \\
\hline SB & Santa Barbara & Davis, T.A. & 742 & $\begin{array}{l}\text { January- } \\
\text { February } 2011\end{array}$ & 1 & 0 & 3 \\
\hline HR & $\begin{array}{l}\text { Santa Cruz, San Gabriel, and Peninsular } \\
\text { Range Hard Rock Aquifers }\end{array}$ & Davis, T.A. & $\begin{array}{l}\text { DSR in } \\
\text { review }\end{array}$ & $\begin{array}{l}\text { March 2011- } \\
\quad \text { March } 2012\end{array}$ & 2 & 1 & 12 \\
\hline S1-NSF & $\begin{array}{l}\text { North San Francisco Bay Shallow } \\
\text { Aquifer }\end{array}$ & Bennett, G.L. & $\begin{array}{l}\mathrm{DSR} \text { in } \\
\text { review }\end{array}$ & April-August 2012 & 0 & 0 & 8 \\
\hline
\end{tabular}

${ }^{1}$ Blanks collected prior to October 2009 were included in this assessment as a basis of comparison only. Updated study reporting levels were calculated using results for field blanks collected October 2009 through March 2013.

${ }^{2}$ Only blanks collected starting in March 2009 were included in this assessment. 
Groundwater samples collected for the GAMA-PBP were analyzed for a suite of constituents, including trace elements. Trace elements occur naturally and help define water characteristics and quality. Trace elements analyzed were as follows:

$\begin{array}{lll}\text { aluminum }(\mathrm{Al}) & \text { antimony }(\mathrm{Sb}) & \text { arsenic }(\mathrm{As}) \\ \text { barium }(\mathrm{Ba}) & \text { beryllium }(\mathrm{Be}) & \text { boron }(\mathrm{B}) \\ \text { cadmium }(\mathrm{Cd}) & \text { chromium }(\mathrm{Cr}) & \text { cobalt }(\mathrm{Co}) \\ \text { copper }(\mathrm{Cu}) & \text { iron }(\mathrm{Fe}) & \text { lead }(\mathrm{Pb}) \\ \text { lithium }(\mathrm{Li}) & \text { manganese }(\mathrm{Mn}) & \text { molybdenum }(\mathrm{Mo}) \\ \text { nickel }(\mathrm{Ni}) & \text { selenium }(\mathrm{Se}) & \text { silver }(\mathrm{Ag}) \\ \text { strontium }(\mathrm{Sr}) & \text { thallium }(\mathrm{Tl}) & \text { tungsten }(\mathrm{W}) \\ \text { uranium }(\mathrm{U}) & \text { vanadium }(\mathrm{V}) & \text { zinc }(\mathrm{Zn})\end{array}$

Concentrations of constituents can be compared with drinking-water standards established by the U.S. Environmental Protection Agency (USEPA) and the California Department of Public Health (CDPH) to provide some context for the results (U.S. Environmental Protection Agency, 2013; California Department of Public Health, 2013a). These benchmarks are set to protect human health or to limit the presence of constituents that could affect the aesthetic or technical qualities of drinking water, such as taste, odor, scaling, or staining. Although these drinking-water benchmarks are used for comparison purposes, they do not apply to the groundwater samples collected to characterize the quality of untreated drinking water. Most of the trace elements have USEPA and CDPH maximum contaminant levels (MCLs-US and MCLs-CA, respectively) or CDPH secondary maximum contaminant levels (SMCLs-CA). Other benchmarks include the CDPH notification level (NL-CA), USEPA action level (AL-US), and USEPA lifetime health advisory level (HAL-US). More information about these benchmarks can be found in the Glossary.

The GAMA-PBP follows rigorous quality-assurance (QA) plans that adhere to protocols defined by the NAWQA Program (Koterba and others, 1995) and described in the National Field Manual for the Collection of Water-Quality Data (U.S. Geological Survey, variously dated). Qualitycontrol (QC) samples were collected at about 10 percent of the wells to evaluate potential contamination, as well as bias and variability of the data that may have resulted from sample collection, processing, storage, transportation, and laboratory analysis. QC samples included source-solution, equipment, and field blanks, replicates, and matrix spikes. Assessments of the QC data for the GAMA study units are given in their respective Data Series reports (DSRs) (table 1).

The primary laboratory used to analyze samples, the National Water Quality Laboratory (NWQL) in Denver, Colorado, follows a thorough QA plan described by Stevenson (2013). Laboratory QC samples, including laboratory method blanks, continuing calibration verification checks, reagent spikes, certified standard reference materials, and external blind proficiency samples, are analyzed regularly. The NWQL maintains certification by the National Environmental
Laboratory Accreditation Program (NELAP) and other certifications (http://nwql.usgs.gov/Public/lab_cert.shtml). In addition, the Branch of Quality Systems (BQS) within the USGS Office of Water Quality maintains independent oversight of QA at the NWQL and coordinates blind testing of blanks and reference samples through two QA projects: the Blind Blank Project (BBP) and the Inorganic Blind Sample Project (IBSP). Between 2006 and 2012, the BQS conducted a long-term method detection levels (LT-MDLs) project, in which data from the BBP were analyzed to determine appropriate detection levels for constituents on an annual basis (see the report section "Laboratory Analysis and Reporting Methods for Trace Elements" for details). More information about the BQS and its projects can be found at the BQS website http://bqs.usgs.gov/.

To assess any potential bias in trace-element results from field or laboratory contamination, Olsen and others (2010) evaluated QC data collected by the GAMA-PBP from May 2004 to January 2008. Data included source-solution and field blanks that were collected along with the groundwater samples, as well as laboratory performance information and blank-water certificates of analyses provided by the NWQL and BQS. The evaluation determined the frequency and magnitude of trace-element contamination bias throughout this period based on results from field blanks and BQS blind blanks. Each trace element found to have contamination bias was assigned a study reporting level (SRL) at the respective $90^{\text {th }}$ percentile concentration observed in the field blanks by using the binomial probability distribution for greater than 90 percent confidence (hereinafter called the "BD-90/90" concentration) to ensure that no more than 10 percent of detections in groundwater samples could be attributed to extrinsic contamination (contamination originating from a process or source external to the medium being sampled). Since 2008, the concentrations and detection frequencies in field blanks collected by the GAMA-PBP have fluctuated, indicating that the datasets used by Olsen and others (2010) for May 2004 to January 2008 may not be representative of results from more recent GAMA-PBP study units.

\section{Purpose and Scope}

This report describes the methodology and results for the evaluation of data derived from trace-element field and equipment blanks collected along with groundwater samples from March 2006 through March 2013 by the GAMA-PBP. This evaluation determined when trace-element contamination bias in field blanks changed and updated the SRLs defined by Olsen and others (2010) as necessary for results reported by the GAMAPBP. Potential sources of contamination to the field blanks and groundwater samples are discussed in the context of the results of blank-water certificates of analysis, capsule-filter certificates of analysis, source-solution blanks, internal laboratory checks, and third-party laboratory blind QC samples and blanks. The updated SRLs were set to minimize potential contamination bias 
in groundwater-quality results while maintaining consistent and accurate reporting levels for comparison and interpretation of data over extended periods of time. Trace-element field blanks collected during the previous evaluation were included as a basis of comparison for more recent blanks. Some blanks collected by the NAWQA Program using the same protocols and equipment and collected by the same personnel as the GAMA-PBP were included in this evaluation.

\section{Methods}

This study used specific methods to collect groundwater and associated QC samples, analyze these samples and report the results, compile the field and laboratory QC data, and evaluate the combined data to characterize any potential bias that could affect the groundwater sample results. These methods are described below.

\section{Sampling Methods for Trace Elements}

Groundwater samples to be used for trace-element analysis were collected in accordance with the protocols established by the NAWQA Program (Koterba and others, 1995) and the USGS National Field Manual (NFM; U.S. Geological Survey, variously dated). The objective of these protocols is to ensure that a groundwater sample collected from a well represents the aquifer accessed by that well and that samples are handled in a consistent way that minimizes the potential for extrinsic contamination.

Prior to collection of samples, each well was pumped continuously to purge at least 3 casing-volumes of water from the well until field parameters (water temperature, specific conductance, $\mathrm{pH}$, and dissolved oxygen) were stable (Wilde, 2006). Wells were sampled by using Teflon ${ }^{\circledR}$ tubing with stainless-steel fittings attached to a sampling point (hose bib) on the well discharge pipe as close to the well head as possible. At some wells, additional fittings made of brass, steel, or stainless steel were used to connect to the well. Sampling points were located upstream of any well treatment system or water storage tank, except for infrequent cases in which this was not possible. Samples were collected either at the well head by using a short length of Teflon ${ }^{\circledR}$ tubing attached to a stainless-steel connector (referred to in this report as "short lines") or from within an enclosed chamber inside a mobile laboratory that was linked to the well head by Teflon ${ }^{\circledR}$ tubing 10 to 50 feet in length with stainless-steel connectors (referred to as "long lines") (Lane and others, 2003). All fittings and lengths of tubing were cleaned thoroughly between sampling events with, at minimum, non-phosphate laboratory detergent (Liquinox ${ }^{\mathrm{TM}}$ ) followed by thorough rinses with tap water, deionized water, and methanol, followed by a final rinse with deionized blank water (Wilde, 2004). Starting in 2011, the GAMA-PBP discontinued sampling with long lines, in part, to avoid use of methanol in the field; however, methanol continued to be used for cleaning short lines in the USGS water science center (WSC) laboratories. Other modifications of the NFM that pertain to the cleaning of equipment are the omission of 5 percent (by volume) hydrochloric acid for rinsing either short or long lines and the replacement of the pesticide-grade organic blank water with deionized water for the final rinse solution when cleaning short lines.

Groundwater samples to be analyzed for trace elements were filtered by using 0.45 -micrometer pore-size capsule filters from the Pall Corporation (Port Washington, New York). The filters had been pre-rinsed within 1 week of use with 1 to 2 liters (L) of deionized water that was produced in USGS WSC laboratories in California by using reverseosmosis systems that are maintained and quality-assured on a regular basis. The filters were rinsed again at each field site with ambient groundwater before collecting the sample. For most springs or horizontal-well sites that did not have enough pressure to run water through the filter, the turbidity was measured, and samples were not filtered if turbidity was less than 1 nephelometric turbidity unit (NTU); unfiltered samples were processed and analyzed in the same fashion as filtered samples. Springs and horizontal-well sites only account for approximately 2 percent (59 out of 2,552 sites) of all sites sampled by the GAMA-PBP. Groundwater samples for traceelement analysis were collected into acid-rinsed 250-milliliter $(\mathrm{mL})$ polyethylene bottles that had been pre-rinsed with deionized water and then native water, as described by Wilde (2009). Samples were then preserved with certified 7.5-normal (N) nitric acid to a $\mathrm{pH}$ of 2 or less. Collection and preservation chambers were typically not used when sampling with short lines, which is a modification of the NFM.

Field blanks were collected for about 10 percent of the groundwater samples collected from well sites (approximately 270 field blanks for 2,700 groundwater samples) to determine if equipment or procedures used in the field or laboratory introduced contamination to the samples. Portable diaphragm pumps were used to pump blank water through the fittings, spigot, and sample line. Teflon tubing was used at the pump inlet and outlet to connect to the sample-collection equipment. Field blanks were collected at well sites by pumping at least 4 to $8 \mathrm{~L}$ of blank water through the clean sample-collection equipment to simulate the well-purging step and then pumping additional blank water through the equipment to be collected as blank samples, following the same protocols as were used for the groundwater samples, including filtration and preservation. The minimum volume of blank water needed for the final rinse before collecting each field blank was calculated on the basis of tubing volume as described in the NFM (Wilde, 2004). In rare cases, the blank water was poured, rather than pumped, through the equipment.

Equipment blanks were typically collected at the beginning of sampling for a new study unit and in a clean environment, usually inside the mobile laboratory at the USGS WSCs. Equipment blanks were collected and processed by using the same protocol as used for the field blanks. These blanks were used to assess contamination of samples by 
the sample-collection equipment, sample-collection and processing techniques, and equipment cleaning. If the portable pumps or sampling equipment had been stored and not in use for an extended period, the equipment was re-cleaned prior to any blank collection.

For this assessment, it was assumed that the portable pump equipment used to pump blank water through the sample equipment was not a significant source of contamination when cleaned regularly. No blanks were collected to test only the pump equipment. It was also assumed that results from field and equipment blanks were considered indistinguishable; at this time, there are no known sources of contamination for trace-element samples that would affect field blanks but not equipment blanks.

Source-solution blanks were collected whenever a new lot of water was shipped from the NWQL to verify that the blank water used for the field blanks was free of analytes of interest. Source-solution blanks were collected by pouring blank water directly into sample containers that were then preserved, stored, and shipped in the same manner as the groundwater samples. These source-solution blanks were used to supplement additional analyses that had been performed at the NWQL in certifying the quality of the blank water.

\section{Laboratory Analysis and Reporting Methods for Trace Elements}

Groundwater and QC samples collected for trace-element analysis were shipped within a few days of collection to the USGS NWQL in Denver, Colorado. Each trace element was analyzed by using one of three methods as indicated in table 2: inductively coupled plasma with mass spectrometry (ICP-MS); collision-cell inductively coupled plasma with mass spectrometry (cICP-MS); or inductively coupled plasma with atomic-emission spectroscopy (ICP-AES) (Fishman, 1993; Garbarino, 1999; Garbarino and others, 2006). The trace elements analyzed were on the USGS California Water Science Center Schedule 1948 or NAWQA Schedule 2710.

The USGS NWQL uses the LT-MDL and laboratory reporting level (LRL) conventions for reporting trace-element data to minimize risk of false positives and negatives. The LT-MDL concentration for each constituent is statistically derived so that the risk of reporting false positives is no more than 1 percent (Childress and others, 1999). The LT-MDL is calculated as follows, based on a modification of the USEPA method detection limit (MDL) (U.S. Environmental Protection Agency, 1997; Childress and others, 1999):

$$
L T-M D L=s \times t_{(n-1.1-x=0.99)}
$$

where

$n \quad$ is the number of blanks,

$s \quad$ is the standard deviation of measured concentrations of $n$ blank determinations, $t \quad$ is the Students $t$ value at $n-1$ degrees of freedom and $1-\alpha$ (99 percent) confidence level, and

$\alpha \quad$ is the level of significance.

Historically, LT-MDL concentrations had been determined by analyzing a series of low-concentration replicate reagent spikes (near the anticipated LT-MDL) over a 6- to 12-month period. Since 2006, the BQS more directly assessed LT-MDLs based on blind-blank results over an entire year by assuming that the blank concentrations follow a normal distribution (Connor, 2012). As part of the BQS LT-MDL Project, the BQS suggested updated LT-MDL concentrations for each water year (October through September) for 2010 through 2013 based on the greatest value of three approaches: (1) the $99^{\text {th }}$ percentile of blind-blank concentrations (which was most common), (2) the LT-MDL calculated by using equation 1 , or (3) the $99^{\text {th }}$ percentile of internal laboratory-blank concentrations (Connor, 2012). The values were calculated from blank results for the previous year. The $99^{\text {th }}$ percentile concentration was estimated as the second-highest-ranked blind-blank concentration when there were less than $(<) 100$ samples.

Prior to October 1, 2010, each trace-element result with a concentration less than the LT-MDL was a nondetection reported as $<$ LRL (U.S. Geological Survey, 2010). The LRL is usually set at two times the LT-MDL for each constituent and is used to control false-negative error. The probability of reporting a false negative for a sample that contains a concentration of a constituent greater than or equal to the LRL is predicted to be less than or equal to 1 percent. A value between the LT-MDL and LRL was given the remark code "E." E-coded values have a high likelihood of being greater than zero, but can have a high degree of uncertainty in the precise concentration. In 2010, the NWQL changed its reporting convention in order to simplify subsequent statistical evaluations as described by Helsel $(2005,2006)$. Starting in October 2010, the LT-MDL replaced the LRL as the reporting level so that a trace-element result with a concentration less than the LT-MDL was a nondetection reported as $<$ LT-MDL. The probability of reporting a false negative for a sample with a true concentration greater than or equal to the LT-MDL is less than or equal to 50 percent (U.S. Geological Survey, 2010). The practice of E-coding results between the LT-MDL and LRL was discontinued for trace elements. Currently, the valuequalifier codes " $n$," indicating results between the LT-MDL and LRL, or "b," indicating results less than the lowest calibration standard, are used. The NWQL test ID (consisting of the parameter code and method code) and the highest LT-MDL during October 2009 through March 2013 for each trace element analyzed for the GAMA-PBP are given in table 2.

Until April 2013, the GAMA-PBP generally requested reanalyses of source-solution, field, or equipment blanks if constituents were detected. Requests and rerun results were recorded in an Excel spreadsheet maintained by GAMA-PBP staff. If the new result was within acceptable precision for 
Table 2. Trace elements collected for the U.S. Geological Survey (USGS) Groundwater Ambient Monitoring and Assessment (GAMA) Priority Basin Project, reporting information for the USGS National Water Quality Laboratory (NWQL), and comparative benchmarks.

[The NWQL test ID, consisting of the parameter and method codes, is used to uniquely identify a specific constituent and its analytical method. Method code: PLM43 and PLM40, inductively coupled plasma with mass spectrometry (ICP-MS); PLM10, collision-cell ICP-MS (cICP-MS); PLA11, inductively coupled plasma with atomic-emission spectroscopy (ICP-AES). Benchmark type: Benchmark type and benchmark level as of June 13, 2013.

AL-US, U.S. Environmental Protection Agency (USEPA) action level; HAL-US, USEPA lifetime health advisory level; MCL-CA, California Department of Public Health (CDPH) maximum contaminant level; MCL-US, USEPA maximum contaminant level; NL-CA, CDPH notification level; SMCL-CA, CDPH secondary maximum contaminant level. Maximum contaminant level benchmarks are listed as the MCL-US, or the MCL-CA if no MCL-US exists. Other abbreviations: CAS, Chemical Abstracts Service; LT-MDL, long-term method detection level; LRL, laboratory reporting level; na, not available; $\mu \mathrm{g} / \mathrm{L}$, micrograms per liter]

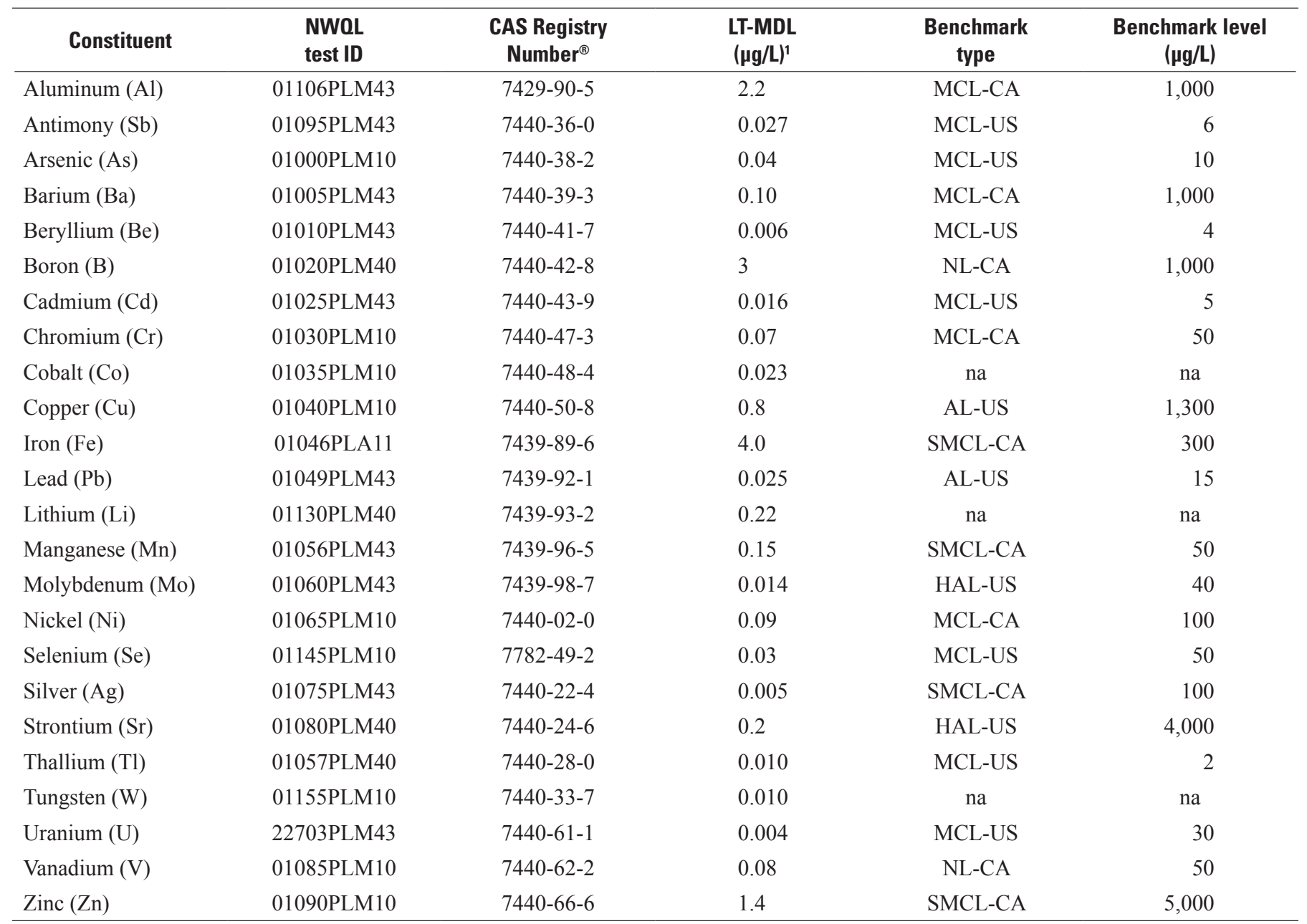

${ }^{1}$ The highest LT-MDL for October 2009 through March 2013 is listed here. LRLs are not shown; the LRL is set at two times the LT-MDL concentration for each constituent.

the method as per the laboratory analysts, then the original concentration was not updated. However, if the new result was accompanied with a note from the laboratory, "Use new result. New result within method precision based on multiple reruns," then the concentration was updated by GAMA-PBP staff in the USGS National Water Information System (NWIS) database, regardless of whether the rerun value was greater or less than the original value.

In January 2008, the NWQL Metals Unit began reporting some results for source-solution, field, and equipment blanks that were already reanalyzed prior to the data being released to the NWIS database, with the comment "Initial result and rerun result within acceptable precision. QC verified." Each sample, regardless of type, that had a percent difference in cation-anion balance greater than 4 was automatically rerun (Douglas L. Stevenson, National Water Quality Laboratory, written commun., 2014). Given that blanks are not expected to contain reportable quantities of cations and anions, most blanks with any detection of an inorganic constituent were reanalyzed, and the initial concentrations may have been replaced by the rerun values. That is, the original detection of a constituent may have been updated to a nondetection or 
with a different concentration prior to data being released, and initial values were not reported. If a result was reanalyzed more than once or other QC parameters were evaluated, then the above laboratory comment was not included with the result. Consequently, results for field blanks may be the internal rerun results, and the number of affected results is unknown because not every updated result is annotated with a laboratory comment.

\section{Data Compilation Methods for Trace Elements}

To build a dataset for evaluation of potential contamination bias, all source-solution, field, and equipment blanks collected for the GAMA-PBP from May 2004 through March 2013 were retrieved from the USGS NWIS database. Blanks collected by using monitoring-well equipment were excluded from the retrieved dataset because their results were not representative of the groundwater sampling for the GAMA-PBP studies. Typical wells sampled for the study have dedicated submersible or turbine pumps, whereas monitoring wells were sampled by using portable, submersible pumps. Samples collected with monitoring-well equipment represented only a small portion of the data collected for the GAMA-PBP studies, and an assessment of the quality of those results is typically done on a study-unit basis. Additionally, field blanks collected prior to March 2006 were excluded because contamination of blanks during May 2004March 2006 was in part attributed to the practice of using universal blank water (UBW), which was discontinued. As discussed by Olsen and others (2010), it was discovered that during storage, some of the lots of UBW had acquired concentrations of aluminum, barium, chromium, iron, manganese, and strontium above their respective LT-MDLs. The hypothesized source was the leaching of these trace elements from the amber-glass UBW bottles. Field-blank samples collected by using UBW were included in the Olsen and others (2010) review because some detections and concentrations of trace elements could not be fully attributed to the contamination of blank water. The NWQL discontinued use of UBW in 2006 and replaced it with organic blank water (OBW) and inorganic blank water (IBW), for the respective organic or inorganic blank collection (USGS NWQL RapiNote 06-022, written commun., June 2006). Blanks collected prior to March 2006 do not represent current protocols, and they were excluded to avoid overestimation of contamination bias for groundwater samples collected from March 2006 through March 2013.

Source-solution, field, and equipment blanks collected for the NAWQA Southern California Coastal Drainages (SOCA) study unit during March 2009 through May 2012 were retrieved to supplement the GAMA-PBP data. The GAMA-PBP and NAWQA SOCA data could be combined because the same equipment and protocols were used and samples were collected by the same personnel for both projects. The NAWQA SOCA data included recent data for samples collected by using long lines, which were useful for comparison purposes because the GAMA-PBP had mostly discontinued the use of long lines by 2010 in favor of short lines. Also, NAWQA data fill in a major gap in the GAMAPBP data during December 2008 through September 2009, when GAMA-PBP operations were suspended according to the Governor's Executive Order to stop work on bond-funded projects in response to a fiscal crisis in California (California State Water Resources Control Board, 2010). The SOCA study unit is part of the NAWQA Program's regional assessments of the status and trends of groundwater quality across the Nation (Lapham and others, 2005). More information about NAWQA water-quality assessments of principal aquifers can be found online at http://water.usgs.gov/nawqa/studies/praq.

Associated groundwater samples and other ancillary data, including sample notes, sample-line types, blank-water lot numbers, and photos for the blanks collected by GAMA-PBP and NAWQA SOCA studies and summaries of blank results in the DSRs for each GAMA-PBP study unit (table 1) were compiled to help interpret the quality-control data. In all, results and information were compiled for samples collected for 29 GAMA-PBP study units from March 2006 through March 2013, 3 NAWQA SOCA studies from March 2009 through May 2012, and NAWQA and GAMA trends assessments from September 2007 through September 2012 (table 1). The dataset includes 38 source-solution blanks; 6 equipment blanks ( 1 short line, 5 long line); and 173 field blanks (101 short line, 56 long line, 16 undetermined) and 173 associated groundwater samples. Three additional field blanks were reviewed and are discussed in the Results section, but were not included in the determinations of revised SRLs because they were not properly filtered. Hereinafter, the equipment blanks are included with the field blanks for calculations and discussions of GAMA-PBP SRLs.

\section{Data Analysis Methods for Evaluating Bias}

Three tools were used to evaluate the trace-element fieldblank data: (1) time-series plots, (2) detection frequencies, and (3) $90^{\text {th }}$ percentile concentrations calculated by using the binomial probability distribution for greater than 90 percent confidence, referred to as the "BD-90/90 concentration" by Olsen and others (2010) and in this report. These tools were used to identify any changes in the frequency and concentrations in detections in field blanks since February 2008 so that SRLs could be revised, if necessary.

Time-series plots facilitate visual identification of trends or temporal components in the data, which might correspond to changes in the conditions under which the field blanks or groundwater samples were collected. Time-series plots of blank results were prepared for each constituent (figs. 3A-O). Nondetections were plotted at their respective LRL or LT-MDL concentrations by using a different symbol than was used for the detections. Detections in source-solution blanks were plotted to aid in identifying instances of potential 
contamination in the source solution (IBW) used for the field blanks. For some constituents with observable contamination bias, additional plots were prepared to compare the field-blank data with the corresponding groundwater sample data.

Detection frequencies calculated from the field-blank data are an easy way to identify potential contamination bias. Detection frequencies were calculated for each trace element by dividing the number of detections by the total number of field blanks. Detection frequencies were compared over different time periods to help identify specific periods of contamination. For the time period used to evaluate recent contamination bias and update SRLs, October 2009 through March 2013, 89 field blanks were analyzed for each of the trace elements except iron (which had 86 field blanks) and tungsten (which had 56 field blanks). For 89 ranked values, the 5th highest value statistically defines the BD-90/90 concentration. Thus, the detection frequency in a population of 89 field blanks must be below 5.6 percent (no more than 4 detections) for the BD-90/90 concentration to be a nondetection. Therefore, a detection frequency of 5 percent was used as a threshold for identifying trace elements requiring additional scrutiny and possible establishment of an SRL.

BD-90/90 concentrations were calculated by using the binomial probability distribution from the method reported by Hahn and Meeker (1991). This nonparametric approach was used to determine the $90^{\text {th }}$ percentile of potential extrinsic contamination for each trace element, with 90 percent or greater confidence. Calculations were made by using the BINOMDIST function in Excel 2007 (Microsoft Corporation, Redmond, Washington), which takes the form

$C L=$ BINOMDIST (number_s, trials, probability_s, cumulative)

where

$C L \quad$ is the confidence limit for the specified rank and for the percentile of interest;

number_s is the number of successes in trials, in this case, the specified rank minus 1 ;

trials is the number of trials, in this case, the number of field blanks;

probability_s is the percentile of interest, in this case, 0.90 for the $90^{\text {th }}$ percentile; and

cumulative is a logical value that determines the form of the function, in this case TRUE, such that BINOMDIST returns the cumulative distribution function, which assumes that there are at most (cumulatively) number_s successes.
The BD-90/90 concentrations represent the upper threshold of potential contamination bias of trace-element results. For trace elements that had BD-90/90 concentrations above their respective LT-MDLs, the chance that a concentration below the respective BD-90/90 concentration was significantly affected by extrinsic contamination was greater than 10 percent. For these trace elements, the likely source(s) of contamination was determined, and an SRL was set equal to the BD-90/90 concentration, unless additional lines of evidence supported setting the SRL at a concentration greater than the BD-90/90.

The aforementioned evaluation of field blanks was supplemented by (1) evaluation of internal and third-party laboratory QC data collected by the NWQL and BQS, and (2) evaluations of specific sampling equipment that appeared to be associated with higher frequencies of contamination bias. The range of concentrations, mean concentration, and standard deviation for laboratory-blank analyses were compared with the LT-MDL for each trace element. The range of concentrations (including negative concentrations) and standard deviation of laboratory blanks for each constituent help in evaluating random error affecting the ability of an analytical method to reproduce results (Struzeski, 2012). The modified USEPA MDLs and $99^{\text {th }}$ percentile concentrations for blind blanks submitted for analysis by the BQS and $99^{\text {th }}$ percentile concentrations for laboratory blanks provided by the NWQL were used to evaluate systematic error that can create positive or negative deviations in results from the target value. The $99^{\text {th }}$ percentile was selected by the BQS, in addition to the calculated LT-MDL, as a more direct route for determining the value that ensures that no more than 1 percent of detections are false. For the purpose of this assessment for SRLs, a trace element was considered to have significant positive bias originating from laboratory processes if the $99^{\text {th }}$ percentile concentrations of laboratory blanks or blind blanks were equal to or greater than the LT-MDL for 2 or more of the water years during October 2009 through March 2013. The $99^{\text {th }}$ percentile concentration was used as the SRL for some trace elements showing contamination bias observed in laboratory and blind blanks in addition to field blanks.

Certificates of analysis for the IBW used for the field blanks, source-solution blanks representing the IBW, certificates of analysis for the Pall capsule filters used for the field blanks and the groundwater samples, and the quality of the deionized water used to pre-rinse the capsule filters were reviewed to determine whether any of the bias could be attributed to the blank water (IBW), capsule filters, or deionized water used to rinse the capsule filters. Finally, the resulting SRLs were compared to CDPH or USEPA regulatory 
benchmarks to determine whether or not applying them would affect comparison of groundwater results with these benchmarks. Comparative benchmarks and benchmark types are listed in table 2 and described in the Glossary.

Detections at concentrations below an SRL are considered to have an unacceptably high likelihood of positive bias, and therefore, should be reported as less than or equal to $(\leq)$ the reported value. For example, for a trace element with an SRL of 2.1 micrograms per liter $(\mu \mathrm{g} / \mathrm{L})$, a result of $1.8 \mu \mathrm{g} / \mathrm{L}$ would be reported in the NWIS database as $\leq 1.8 \mu \mathrm{g} / \mathrm{L}$ and with the sample comment "Result is $\leq$ reported value, based on quality-control data (Davis and others, 2014)." By reporting detections below the SRL as less than or equal to the reported value, data users will know the magnitude of each detected concentration and will know that the true concentration could be less than or equal to the detected concentration.

\section{Results}

Results of the evaluation of contamination bias for each trace element were categorized into two groups: (1) trace elements detected in fewer than 5 percent of field blanks and (2) trace elements detected in more than 5 percent of the field blanks for October 2009 through March 2013. Detection frequencies for each trace element in field blanks collected by the GAMA-PBP were calculated for two time periods, March 2006 through September 2009 and October 2009 through March 2013, and tabulated in table 3A. For comparison, raw detection frequencies (prior to applying any SRLs) for the associated groundwater samples were also calculated for the two time periods and tabulated in table 3B. The division into two time periods at October 2009 was determined after reviewing the time-series plots, which showed a shift in the contamination bias in field blanks for many trace elements at that time. Time-series plots of the source-solution and field blanks for the entire time period for each trace element (and groundwater detections for cobalt) along with the LRLs, LT-MDLs, and SRLs are displayed in figures $3 A-O$ and $\underline{4-12}$. A summary of laboratory blanks analyzed at the NWQL is given in table 4. Results of the BQS blind blanks compared to NWQL's LT-MDLs and internal laboratory blanks are given in table 5. SRLs for trace elements based on results from field blanks, laboratory blanks, and BQS blind blanks are given in table 6 .

Three field blanks collected by the GAMA-PBP during October 2009 through March 2013 were not included in the calculations of detection frequencies and BD-90/90 concentrations because they were unfiltered and therefore did not represent typical groundwater-quality sampling. A photo taken of the set-up for one of the omitted field blanks collected in 2010 showed that the capsule filter was connected to the sampling line upside down; this field blank was likely not properly filtered. No trace elements were detected in the field blank; however, the laboratory diluted the sample during analysis, causing the detection limits to be higher than usual. Another unfiltered field blank was collected with a long line and fittings for the NAWQA SOCA study in 2011. Four trace elements were detected: barium $(0.1315 \mu \mathrm{g} / \mathrm{L})$, copper $(2.82 \mu \mathrm{g} / \mathrm{L})$, lead $(0.821 \mu \mathrm{g} / \mathrm{L})$, and zinc $(4.35 \mu \mathrm{g} / \mathrm{L})$. The copper and lead concentrations were greater than the concentrations detected in the subsequent groundwater sample (2.26 and $0.245 \mu \mathrm{g} / \mathrm{L}$, respectively). Lastly, a special field blank was collected in February 2013 with the pump used to collect field blanks and a spigot, but without a sampling line or filter, to test the hypothesis that the filters were the source of bias for cobalt and manganese. The only trace element detected in this field blank was lead $(0.114 \mu \mathrm{g} / \mathrm{L})$, which was greater than the concentration detected in the associated groundwater sample $(0.0532 \mu \mathrm{g} / \mathrm{L})$.

Mercury was included in the previous review of traceelement QC data (Olsen and others, 2010); however, since then, only 17 field blanks were analyzed for mercury. These field blanks were collected from February 2008 through October 2008, and all were nondetections. The previously determined SRL was $0.012 \mu \mathrm{g} / \mathrm{L}$, and contamination from the previous period was attributed to the bottles in which samples were collected. Because the number of samples since February 2008 was too few to provide statistically reliable information, the SRL of $0.012 \mu \mathrm{g} / \mathrm{L}$ was applied for GAMAPBP data collected through October 2008, after which mercury was no longer collected. 
Table 3A. Detection frequencies for trace elements in field blanks collected for the U.S. Geological Survey (USGS) Groundwater Ambient Monitoring and Assessment (GAMA) Priority Basin Project and the National Water-Quality Assessment (NAWQA) Program Southern California Coastal Drainages (SOCA) study unit, March 2006-September 2009 and October 2009-March 2013.

[See table 1 for the number of field blanks included by study unit. Equipment blanks are included in the calculations of detection frequencies for field blanks. The October 2009 through March 2013 period was further divided into two groups depending on the length of sampling line used to collect the field blanks: short lines and long lines. Abbreviations: n, number of samples; =, equal to; >, greater than; $<$, less than; na, not available]

\begin{tabular}{|c|c|c|c|c|}
\hline \multirow{3}{*}{\begin{tabular}{c|} 
Constituent \\
Collection date \\
Number of samples
\end{tabular}} & \multicolumn{4}{|c|}{$\begin{array}{l}\text { Detection frequency in field blanks } \\
\text { (percent) }\end{array}$} \\
\hline & \multirow{2}{*}{$\begin{array}{c}\text { March 2006-September } 2009 \\
(n=90)\end{array}$} & \multicolumn{3}{|c|}{ October 2009-March 2013} \\
\hline & & $(n=89)$ & $\begin{array}{c}\text { short lines } \\
(\mathrm{n}=69)^{1}\end{array}$ & $\begin{array}{l}\text { long lines } \\
(\mathrm{n}=15)^{1}\end{array}$ \\
\hline \multicolumn{5}{|c|}{ Detected in $<5$ percent of field blanks (October 2009-March 2013) } \\
\hline Aluminum (Al) & 4.4 & 1.1 & 1.4 & 0 \\
\hline Antimony (Sb) & 0 & 1.1 & 1.4 & 0 \\
\hline Arsenic (As) & 0 & 2.2 & 1.4 & 6.7 \\
\hline Barium (Ba) & 4.4 & 2.2 & 2.9 & 0 \\
\hline Beryllium (Be) & 0 & 0 & 0 & 0 \\
\hline Boron (B) & 4.4 & 4.5 & $\mathrm{na}^{2}$ & $\mathrm{na}^{2}$ \\
\hline Cadmium (Cd) & 1.1 & 0 & 0 & 0 \\
\hline Chromium (Cr) & 16 & 1.1 & 1.4 & 0 \\
\hline Lithium (Li) & 0 & 0 & 0 & 0 \\
\hline Selenium (Se) & 0 & 0 & 0 & 0 \\
\hline Silver (Ag) & 2.2 & 1.1 & 1.4 & 0 \\
\hline Strontium ( $\mathrm{Sr}$ ) & 1.1 & 0 & 0 & 0 \\
\hline Thallium ( $\mathrm{Tl})$ & 1.1 & 0 & 0 & 0 \\
\hline Uranium (U) & 1.1 & 0 & 0 & 0 \\
\hline Vanadium (V) & 0 & 0 & 0 & 0 \\
\hline \multicolumn{5}{|c|}{ Detected in $>5$ percent of field blanks (October 2009-March 2013) } \\
\hline Cobalt (Co) & 0 & 99 & 99 & 100 \\
\hline Copper $(\mathrm{Cu})$ & 8.9 & 34 & 36 & 27 \\
\hline $\operatorname{Iron}(\mathrm{Fe})^{3}$ & 2.3 & 8.1 & 7.2 & 1.2 \\
\hline Lead $(\mathrm{Pb})$ & 18 & 55 & 57 & 47 \\
\hline Manganese (Mn) & 0 & 76 & 73 & 87 \\
\hline Molybdenum (Mo) & 0 & 7.9 & 8.7 & 6.7 \\
\hline Nickel (Ni) & 8.9 & 5.6 & 5.8 & 6.7 \\
\hline Tungsten $(\mathrm{W})^{3}$ & 1.3 & 5.4 & 6.1 & 0 \\
\hline Zinc (Zn) & 13 & 33 & 36 & 13 \\
\hline
\end{tabular}

${ }^{1}$ The sample-line type could not be determined for five field blanks.

${ }^{2}$ Nine field blanks (four long lines, four short lines, and one undetermined) were collected using blank water observed to be contaminated with boron. Of these nine, eight had detections of boron, and one field blank did not have a boron detection. The field blank with a nondetection was collected with a short line 6 months after the last contaminated field blank was collected.

${ }^{3}$ For March 2006 through September 2009, iron was analyzed for only 87 field blanks and tungsten for only 76 field blanks. For October 2009 through March 2013, iron was analyzed for 86 field blanks (69 short lines, 12 long lines, and 5 undetermined) and tungsten for 56 field blanks (49 short lines and 7 long lines). 
Table 3B. Detection frequencies for trace elements in the associated groundwater samples collected for the U.S. Geological Survey (USGS) Groundwater Ambient Monitoring and Assessment (GAMA) Priority Basin Project and the National Water-Quality Assessment (NAWQA) Program Southern California Coastal Drainages (SOCA) study unit, March 2006-September 2009 and October 2009-March 2013.

[Abbreviations: $\mathrm{n}$, number of samples; =, equal to; >, greater than; $<$, less than]

\begin{tabular}{|c|c|c|}
\hline \multirow{2}{*}{$\begin{array}{c}\text { Constituent } \\
\text { Collection date }\end{array}$} & \multicolumn{2}{|c|}{$\begin{array}{c}\text { Detection frequency in the associated } \\
\text { groundwater samples } \\
\text { (percent) }\end{array}$} \\
\hline & $\begin{array}{c}\text { March 2006- } \\
\text { September } 2009\end{array}$ & $\begin{array}{c}\text { October 2009- } \\
\text { March } 2013\end{array}$ \\
\hline Number of samples & $(n=89)$ & $(n=84)$ \\
\hline \multicolumn{3}{|c|}{ Detected in $<5$ percent of field blanks (October 2009-March 2013) } \\
\hline Aluminum $(\mathrm{Al})$ & 51 & 45 \\
\hline Antimony (Sb) & 38 & 63 \\
\hline Arsenic (As) & 93 & 99 \\
\hline Barium (Ba) & 100 & 100 \\
\hline Beryllium (Be) & 15 & 31 \\
\hline Boron (B) & 98 & 96 \\
\hline Cadmium (Cd) & 30 & 51 \\
\hline Chromium (Cr) & 78 & 69 \\
\hline Lithium (Li) & 96 & 100 \\
\hline Selenium (Se) & 82 & 87 \\
\hline Silver (Ag) & 2 & 16 \\
\hline Strontium (Sr) & 100 & 100 \\
\hline Thallium (Tl) & 4.5 & 10 \\
\hline Uranium (U) & 91 & 95 \\
\hline Vanadium (V) & 96 & 94 \\
\hline \multicolumn{3}{|c|}{ Detected in $>5$ percent of field blanks (October 2009-March 2013) } \\
\hline Cobalt (Co) & 72 & 82 \\
\hline Copper $(\mathrm{Cu})$ & 73 & 57 \\
\hline Iron $(\mathrm{Fe})$ & 54 & 69 \\
\hline Lead $(\mathrm{Pb})$ & 89 & 89 \\
\hline Manganese (Mn) & 79 & 77 \\
\hline Molybdenum (Mo) & 94 & 99 \\
\hline Nickel (Ni) & 94 & 89 \\
\hline Tungsten (W) ${ }^{1}$ & 68 & 76 \\
\hline Zinc (Zn) & 91 & 79 \\
\hline
\end{tabular}

${ }^{1}$ Tungsten was analyzed for 76 associated groundwater samples during March 2006 through September 2009 and 55 associated groundwater samples during October 2009 through March 2013. 
Table 4. Summary of results for U.S. Geological Survey (USGS) National Water Quality Laboratory (NWOL) laboratory blanks analyzed for trace elements, including mean concentrations and standard deviations, March 2006-September 2009 and 0ctober 2009March 2013.

[Analyses of laboratory blanks are reported as raw results without rounding; analytical variability and calibration techniques can cause some results to be negative. Abbreviations: $\mu \mathrm{g} / \mathrm{L}$, micrograms per liter; LT-MDL, long-term method detection level]

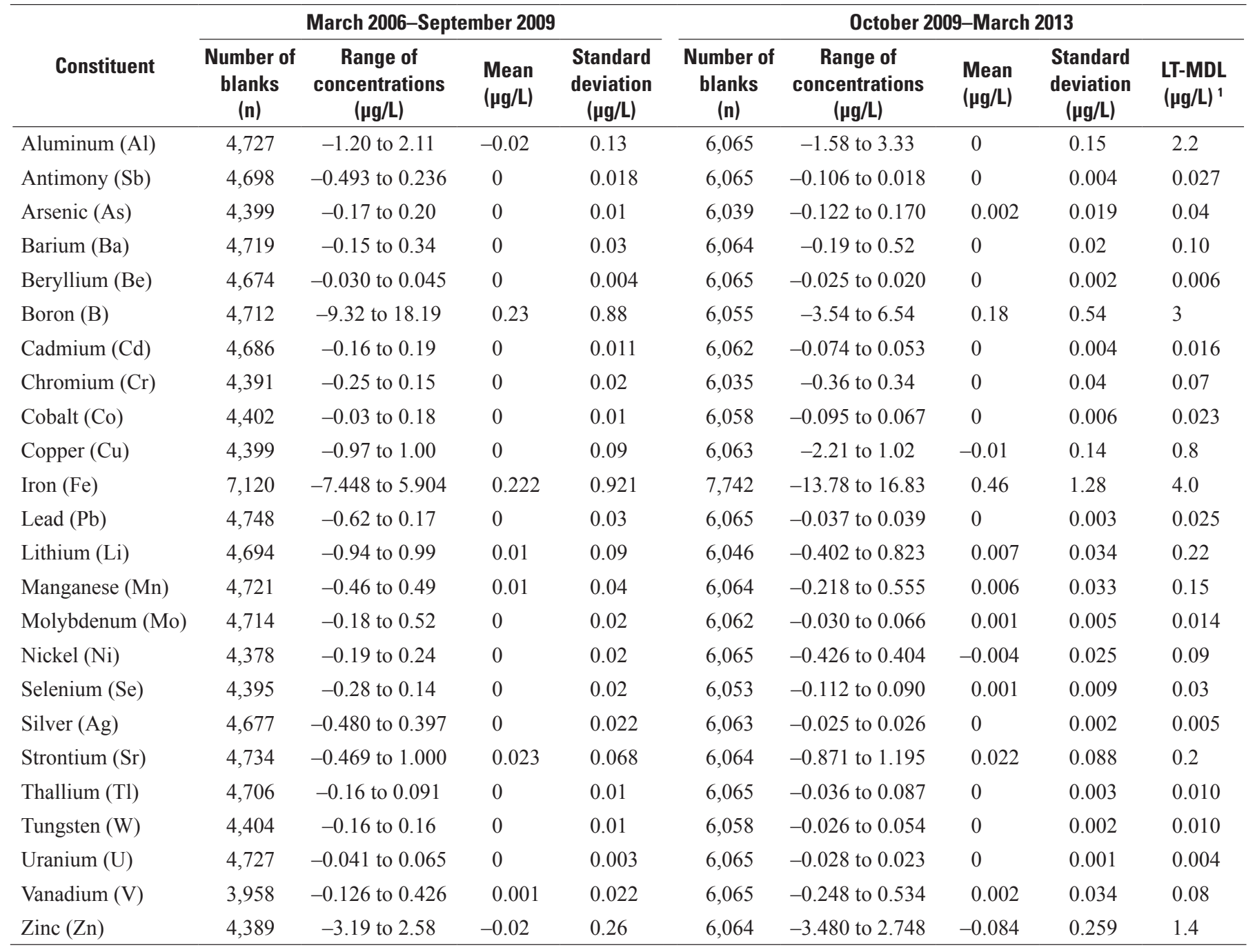

\footnotetext{
${ }^{1}$ The highest LT-MDL for October 2009 through March 2013 is listed here.
} 
Table 5. Summary of long-term method detection level (LT-MDL) calculations for water years 2010-13 by the U.S. Geological Survey (USGS) Branch of Quality Systems (BOS) LT-MDL Project from blind blanks and internal laboratory blanks analyzed by the USGS National Water Quality Laboratory (NWOL) for trace elements.

[The BQS suggested that the LT-MDL for each water year be equal to the greatest of the three values from the previous year: the calculated LT-MDL, $99^{\text {th }}$ percentile concentration for blind blanks, and $99^{\text {th }}$ percentile concentration for laboratory blanks. Results for 2010-12 were compiled from the BQS LT-MDL Project data web pages for ICP-MS and ICP filtered samples: http://bqs. usgs.gov/ltmdl/2011-2012/LTMDL PlotsICPMS Fil.html and http://bqs.usgs.gov/

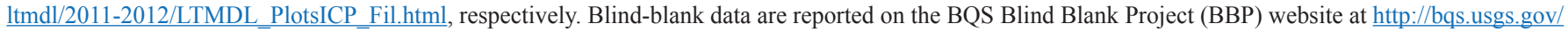
bbp/ (Struzeski, 2013). For water year 2010, blanks were analyzed May 2009 through April 2010; for 2011, May 2010 through April 2011; for 2012, May 2011 through April 2012; and for 2013, May 2012 through April 2013. For each constituent, the number of blind blanks analyzed for each year was between 48 and 53. For each constituent, the number of set blanks for 2010 was approximately 1,922; 2011 was 2,770; and 2012 was 1,826. Abbreviations: ICP, inductively coupled plasma; ICP-MS, inductively coupled plasma with mass spectrometry; $\mu \mathrm{g} / \mathrm{L}$, micrograms per liter; *, concentration is greater than the LT-MDL for that year; na, not available]

\begin{tabular}{|c|c|c|c|c|c|}
\hline Constituent & $\begin{array}{l}\text { Water } \\
\text { year }\end{array}$ & $\begin{array}{c}\text { LT-MDL } \\
\text { ( } \mu \mathrm{g} / \mathrm{L})\end{array}$ & $\begin{array}{c}\text { Calculated LT-MDL } \\
\text { based on blind blanks } \\
(\mu \mathrm{g} / \mathrm{L})^{1}\end{array}$ & $\begin{array}{c}99^{\text {th }} \text { percentile } \\
\text { for blind blanks } \\
(\mu \mathrm{g} / \mathrm{L})^{2}\end{array}$ & $\begin{array}{l}99^{\text {th }} \text { percentile for internal } \\
\text { laboratory blanks } \\
(\mu \mathrm{g} / \mathrm{L})\end{array}$ \\
\hline \multirow[t]{4}{*}{ Aluminum (Al) } & 2010 & 1.7 & 0.79 & $3.6 *$ & 0.2 \\
\hline & 2011 & 1.7 & $2.2 *$ & $4.7 *$ & 0.86 \\
\hline & 2012 & 2.2 & $4.4 *$ & $12.7 *$ & 0.88 \\
\hline & 2013 & 2.2 & na & 0.66 & na \\
\hline \multirow{3}{*}{ Antimony (Sb) } & 2011 & 0.027 & 0.004 & 0.006 & 0.005 \\
\hline & 2012 & 0.027 & 0.003 & 0.004 & 0.004 \\
\hline & 2013 & 0.027 & na & 0.004 & na \\
\hline Arsenic (As) & 2010 & 0.022 & $0.025 *$ & $0.023 *$ & $0.059 *$ \\
\hline \multirow[t]{4}{*}{ Barium (Ba) } & 2010 & 0.07 & 0.02 & 0.02 & 0.05 \\
\hline & 2011 & 0.07 & 0.04 & $0.08 *$ & $0.11 *$ \\
\hline & 2012 & 0.07 & 0.04 & $0.10 *$ & 0.05 \\
\hline & 2013 & 0.10 & na & $0.13 *$ & na \\
\hline \multirow[t]{4}{*}{ Beryllium (Be) } & 2010 & 0.006 & 0.004 & 0.002 & 0.005 \\
\hline & 2011 & 0.006 & 0.004 & 0.004 & 0.006 \\
\hline & 2012 & 0.006 & 0.002 & 0.003 & 0.003 \\
\hline & 2013 & 0.006 & na & 0.004 & na \\
\hline Boron (B) & 2010 & 1.4 & 0.71 & 0.25 & $2.0 *$ \\
\hline Cadmium (Cd) & 2013 & 0.016 & na & 0.008 & na \\
\hline \multirow[t]{4}{*}{ Chromium (Cr) } & 2010 & 0.06 & 0.04 & 0.05 & 0.06 \\
\hline & 2011 & 0.06 & 0.03 & $0.07 *$ & $0.16 *$ \\
\hline & 2012 & 0.07 & 0.03 & 0.03 & $0.15 *$ \\
\hline & 2013 & 0.07 & na & $0.10 *$ & na \\
\hline
\end{tabular}


Table 5. Summary of long-term method detection level (LT-MDL) calculations for water years 2010-13 by the U.S. Geological Survey (USGS) Branch of Quality Systems (BOS) LT-MDL Project from blind blanks and internal laboratory blanks analyzed by the USGS National Water Quality Laboratory (NWOL) for trace elements. - Continued

[The BQS suggested that the LT-MDL for each water year be equal to the greatest of the three values from the previous year: the calculated LT-MDL, $99^{\text {th }}$ percentile concentration for blind blanks, and $99^{\text {th }}$ percentile concentration for laboratory blanks. Results for 2010-12 were compiled from the BQS LT-MDL Project data web pages for ICP-MS and ICP filtered samples: http://bqs.usgs.gov/ltmdl/2011-2012/LTMDL PlotsICPMS Fil.html and http://bqs.usgs.gov/ ltmdl/2011-2012/LTMDL PlotsICP Fil.html, respectively. Blind-blank data are reported on the BQS Blind Blank Project (BBP) website at http://bqs.usgs.gov/ bbp/ (Struzeski, 2013). For water year 2010, blanks were analyzed May 2009 through April 2010; for 2011, May 2010 through April 2011; for 2012, May 2011 through April 2012; and for 2013, May 2012 through April 2013. For each constituent, the number of blind blanks analyzed for each year was between 48 and 53. For each constituent, the number of set blanks for 2010 was approximately 1,922; 2011 was 2,770; and 2012 was 1,826. Abbreviations: ICP, inductively coupled plasma; ICP-MS, inductively coupled plasma with mass spectrometry; $\mu \mathrm{g} / \mathrm{L}$, micrograms per liter; *, concentration is greater than the LT-MDL for that year; na, not available]

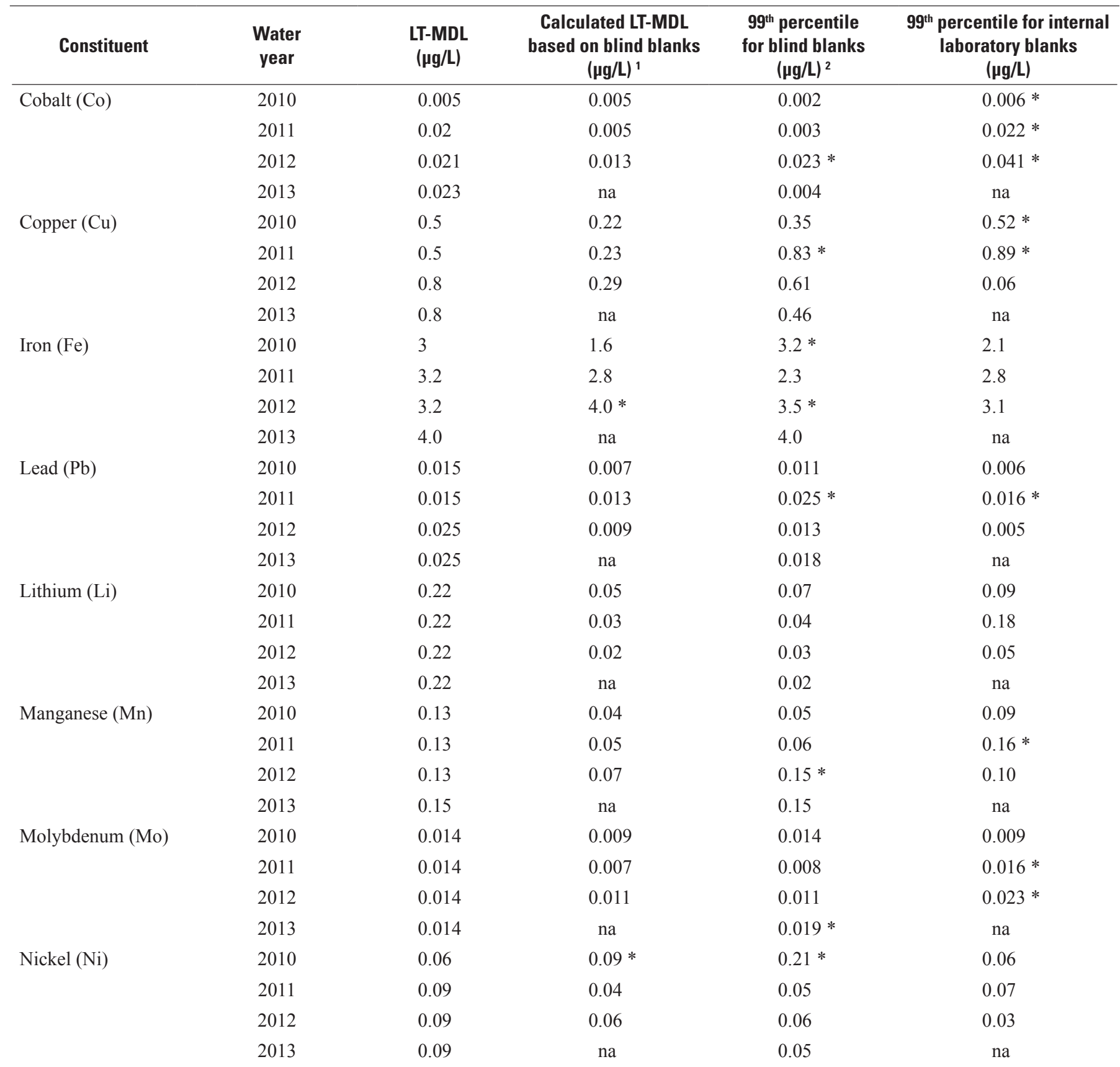


Table 5. Summary of long-term method detection level (LT-MDL) calculations for water years 2010-13 by the U.S. Geological Survey (USGS) Branch of Quality Systems (BOS) LT-MDL Project from blind blanks and internal laboratory blanks analyzed by the USGS National Water Quality Laboratory (NWOL) for trace elements. - Continued

[The BQS suggested that the LT-MDL for each water year be equal to the greatest of the three values from the previous year: the calculated LT-MDL, $99^{\text {th }}$ percentile concentration for blind blanks, and $99^{\text {th }}$ percentile concentration for laboratory blanks. Results for 2010-12 were compiled from the BQS LT-MDL Project data web pages for ICP-MS and ICP filtered samples: http://bqs.usgs.gov/ltmdl/2011-2012/LTMDL PlotsICPMS Fil.html and http://bqs.usgs.gov/

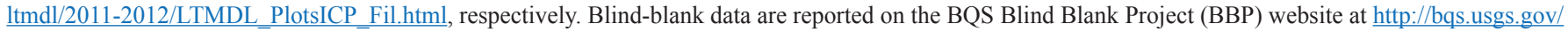
bbp/ (Struzeski, 2013). For water year 2010, blanks were analyzed May 2009 through April 2010; for 2011, May 2010 through April 2011; for 2012, May 2011 through April 2012; and for 2013, May 2012 through April 2013. For each constituent, the number of blind blanks analyzed for each year was between 48 and 53. For each constituent, the number of set blanks for 2010 was approximately 1,922; 2011 was 2,770; and 2012 was 1,826. Abbreviations: ICP, inductively coupled plasma; ICP-MS, inductively coupled plasma with mass spectrometry; $\mu \mathrm{g} / \mathrm{L}$, micrograms per liter; *, concentration is greater than the LT-MDL for that year; na, not available]

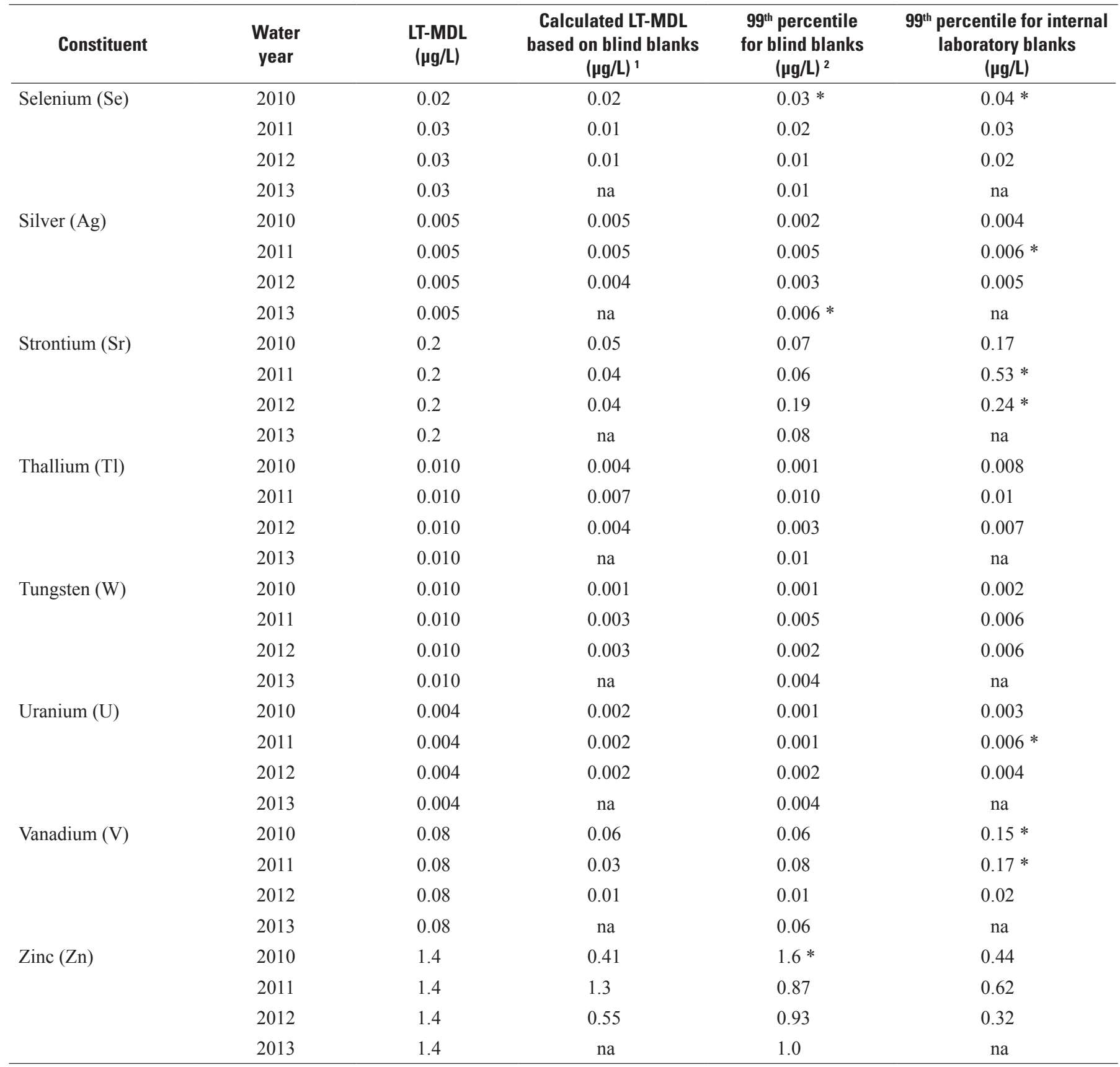

${ }^{1}$ The calculated LT-MDL is based on a modification, described by Childress and others (1999) and Connor (2012), of the U.S. Environmental Protection Agency method detection limit (U.S. Environmental Protection Agency, 1997).

\footnotetext{
${ }^{2}$ The BQS used the second-highest-ranked concentration measured in blind blanks to estimate the $99^{\text {th }}$ percentile.
} 
Table 6. Summary of updated study reporting levels (SRLs) for trace-element data collected for the U.S. Geological Survey (USGS) Groundwater Ambient Monitoring and Assessment (GAMA) Priority Basin Project, October 2009 through March 2013.

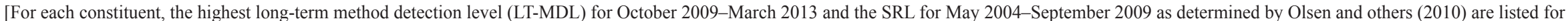

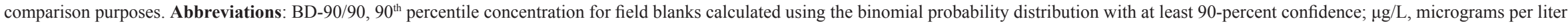
—, nondetection; BQS, Branch of Quality Systems; NAWQA, National Water-Quality Assessment Program; NWIS, USGS National Water Information System]

\begin{tabular}{|c|c|c|c|c|c|}
\hline Constituent & $\begin{array}{l}\text { Highest } \\
\text { LT-MDL for } \\
\text { October 2009- } \\
\text { March } 2013 \\
\text { ( } \mu \mathrm{g} / \mathrm{L})\end{array}$ & $\begin{array}{l}\text { SRL for } \\
\text { May 2004- } \\
\text { September 2009 } \\
(\mu \mathrm{g} / \mathrm{L})\end{array}$ & $\begin{array}{l}\text { BD-90/90 } \\
\text { concentration for } \\
\text { October 2009- } \\
\text { March } 2013 \\
(\mu \mathrm{g} / \mathrm{L})\end{array}$ & $\begin{array}{l}\text { Updated } \\
\text { SRL starting } \\
\text { October } 2009 \\
\quad(\mu \mathrm{g} / \mathrm{L})\end{array}$ & Basis for selecting the updated SRL \\
\hline $\begin{array}{l}\text { Aluminum } \\
\text { (Al) }\end{array}$ & 2.2 & 1.6 & - & none & $\begin{array}{l}\text { SRL was updated for aluminum from } 1.6 \mu \mathrm{g} / \mathrm{L} \text { to none starting October } 2009 \text {, based on the low } \\
\text { detection frequency and BD-90/90 calculated from field-blank data. Contamination bias was not } \\
\text { observed in laboratory, source-solution, and field blanks. However, positive bias was observed in } \\
\text { BQS blind blanks: the calculated LT-MDL concentrations and } 99^{\text {th }} \text { percentile concentrations for } \\
\text { blind blanks were greater than the LT-MDLs in place for aluminum during water years } 2010-12 \text {. }\end{array}$ \\
\hline $\begin{array}{l}\text { Antimony } \\
(\mathrm{Sb})\end{array}$ & 0.027 & none & - & none & $\begin{array}{l}\text { No SRL was necessary for antimony, based on the low detection frequency and BD-90/90 } \\
\text { calculated from field-blank data. Positive bias was generally low for laboratory blanks and BQS } \\
\text { blind blanks. }\end{array}$ \\
\hline Arsenic (As) & 0.04 & none & - & none & $\begin{array}{l}\text { No SRL was necessary for arsenic, based on low detection frequency and BD-90/90 calculated } \\
\text { from field-blank data. Caution should be used when interpreting groundwater concentrations for } \\
\text { arsenic near the detection level because the } 99^{\text {th }} \text { percentile concentrations for laboratory and BQS } \\
\text { blind blanks and calculated LT-MDLs for blind blanks were greater than the LT-MDLs in place } \\
\text { for arsenic during water years } 2010-13 \text {. }\end{array}$ \\
\hline Barium $(\mathrm{Ba})$ & 0.10 & 0.36 & - & none & $\begin{array}{l}\text { SRL was updated for barium from } 0.36 \mu \mathrm{g} / \mathrm{L} \text { to none starting October } 2009 \text {, based on low detection } \\
\text { frequency and BD-90/90 calculated from field-blank data. Caution should be used when } \\
\text { interpreting groundwater concentrations for barium near the detection level because the } 99^{\text {th }} \\
\text { percentile concentrations for blind blanks during water years } 2011-13 \text { and for laboratory blanks } \\
\text { during } 2011 \text { were greater than the LT-MDLs in place for barium. }\end{array}$ \\
\hline $\begin{array}{l}\text { Beryllium } \\
\quad(\mathrm{Be})\end{array}$ & 0.006 & none & - & none & $\begin{array}{l}\text { No SRL was necessary for beryllium, based on the low detection frequency and BD-90/90 } \\
\text { calculated from field-blank data. Positive bias was generally low for laboratory blanks and BQS } \\
\text { blind blanks. }\end{array}$ \\
\hline Boron (B) & 3 & none & - & none & $\begin{array}{l}\text { No SRL was necessary for boron because the range of contamination observed in the field blanks } \\
\text { could be entirely attributed to concentrations (up to } 30 \mu \mathrm{g} / \mathrm{L} \text { ) observed in the source water that } \\
\text { composed these blanks. There were no other known sources of contamination, and laboratory } \\
\text { and BQS quality-control results were generally within acceptable limits. }\end{array}$ \\
\hline $\begin{array}{l}\text { Cadmium } \\
\text { (Cd) }\end{array}$ & 0.016 & none & - & none & $\begin{array}{l}\text { No SRL was necessary for cadmium, based on the low detection frequency and BD-90/90 } \\
\text { calculated from field-blank data. Positive bias was generally low for laboratory blanks and BQS } \\
\text { blind blanks. }\end{array}$ \\
\hline Chromium & 0.07 & 0.42 & - & none & SRL was updated for chromium from $0.42 \mu \mathrm{g} / \mathrm{L}$ to none starting October 2009 , based on the low \\
\hline
\end{tabular}
detection frequency and BD-90/90 calculated from field-blank data. Caution should be used when interpreting groundwater concentrations for chromium near the detection level because the $99^{\text {th }}$ percentile concentrations for laboratory and BQS blind blanks were greater than the LTMDLs in place for chromium during waters years 2011-13. 
Table 6. Summary of updated study reporting levels (SRLs) for trace-element data collected for the U.S. Geological Survey (USGS) Groundwater Ambient Monitoring and Assessment (GAMA) Priority Basin Project, October 2009 through March 2013.-Continued

[For each constituent, the highest long-term method detection level (LT-MDL) for October 2009-March 2013 and the SRL for May 2004-September 2009 as determined by Olsen and others (2010) are listed for

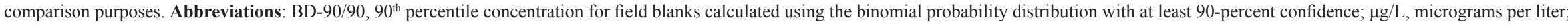
—, nondetection; BQS, Branch of Quality Systems; NAWQA, National Water-Quality Assessment Program; NWIS, USGS National Water Information System]

\begin{tabular}{|c|c|c|c|c|c|}
\hline Constituent & $\begin{array}{c}\text { Highest } \\
\text { LT-MDL for } \\
\text { October 2009- } \\
\text { March } 2013 \\
\text { ( } \mu \mathrm{g} / \mathrm{L})\end{array}$ & $\begin{array}{c}\text { SRL for } \\
\text { May 2004- } \\
\text { September 2009 } \\
(\mu \mathrm{g} / \mathrm{L})\end{array}$ & $\begin{array}{c}\text { BD-90/90 } \\
\text { concentration for } \\
\text { October 2009- } \\
\text { March 2013 } \\
\text { ( } \mu \mathrm{g} / \mathrm{L})\end{array}$ & $\begin{array}{c}\text { Updated } \\
\text { SRL starting } \\
\text { October } 2009 \\
(\mu \mathrm{g} / \mathrm{L})\end{array}$ & Basis for selecting the updated SRL \\
\hline Cobalt (Co) & 0.023 & none & 0.38 & $\begin{array}{l}\text { Report all } \\
\text { results as } \\
\text { "reviewed } \\
\text { and } \\
\text { rejected" }\end{array}$ & $\begin{array}{l}\text { All groundwater results for cobalt starting October } 2009 \text { were coded as "reviewed and rejected" } \\
\text { in the NWIS database, based on increased contamination of field blanks attributed to the } \\
\text { capsule filters used to filter samples starting October } 2009 \text {. An upper limit of contamination for } \\
\text { groundwater samples could not be determined. The detection frequency of cobalt for field blanks } \\
\text { was greater than for groundwater samples, and concentrations were comparable between the } \\
\text { sample types. }\end{array}$ \\
\hline
\end{tabular}

Copper $(\mathrm{Cu})$

Iron $(\mathrm{Fe})$

Lead $(\mathrm{Pb})$

0.2

$(\mathrm{Mn})$

0.15
0.019
2.1

RL was updated for copper from 1.7 to $2.1 \mu \mathrm{g} / \mathrm{L}$ starting October 2009, based on increased contamination of field blanks, likely due to the equipment and (or) sampling processes. The SRL is equal to the BD-90/90 concentration for field blanks collected from October 2009 through March 2013. Positive bias was relatively low in laboratory and BQS blind blanks after the LTMDL increased for copper in 2012 from 0.5 to $0.8 \mu \mathrm{g} / \mathrm{L}$.

SRL for iron remained at the previous SRL of $6 \mu \mathrm{g} / \mathrm{L}$, based on continued contamination of field blanks collected from October 2009 through March 2013, and based on positive bias observed in BQS blind blanks. The calculated LT-MDL concentration and (or) the $99^{\text {th }}$ percentile concentrations for blind blanks were greater than the LT-MDLs in place for iron during water years 2010 and 2012

SRL was updated for lead from 0.65 to $0.82 \mu \mathrm{g} / \mathrm{L}$ starting October 2009 , based on increased contamination of field blanks likely due to the equipment and (or) sampling processes. The SRL is equal to the BD-90/90 concentration for October 2009 through March 2013. Positive bias was generally low for laboratory blanks and BQS blind blanks.

No SRL was necessary for lithium, based on the low detection frequency and BD-90/90 calculated from field-blank data. Positive bias was generally low for laboratory blanks and BQS blind blanks.

SRL was updated for manganese from 0.2 to $0.66 \mu \mathrm{g} / \mathrm{L}$ starting October 2009, based on increased contamination of field blanks attributed to the capsule filters used to filter samples. The SRL is equal to the BD-90/90 concentration for October 2009 through March 2013. Additionally, the $99^{\text {th }}$ percentile concentrations for laboratory blanks during water year 2011 and for BQS blind blanks during 2012 were greater than the LT-MDL in place for manganese.

0.023 SRL was updated for molybdenum from none to $0.023 \mu \mathrm{g} / \mathrm{L}$ starting October 2009, based on increased contamination of field blanks, and based on positive bias observed in laboratory and BQS blind blanks. The $99^{\text {th }}$ percentile concentrations for laboratory blanks during water years 2011-12 and for blind blanks during 2013 were greater than the LT-MDLs in place for molybdenum. The SRL is equal to the highest $99^{\text {th }}$ percentile concentration for laboratory blanks. 
Table 6. Summary of updated study reporting levels (SRLs) for trace-element data collected for the U.S. Geological Survey (USGS) Groundwater Ambient Monitoring and Assessment (GAMA) Priority Basin Project, October 2009 through March 2013.-Continued

[For each constituent, the highest long-term method detection level (LT-MDL) for October 2009-March 2013 and the SRL for May 2004-September 2009 as determined by Olsen and others (2010) are listed for comparison purposes. Abbreviations: BD-90/90, $90^{\text {th }}$ percentile concentration for field blanks calculated using the binomial probability distribution with at least 90 -percent confidence; $\mu \mathrm{g} / \mathrm{L}$, micrograms per liter; - , nondetection; BQS, Branch of Quality Systems; NAWQA, National Water-Quality Assessment Program; NWIS, USGS National Water Information System]

\begin{tabular}{|c|c|c|c|c|c|}
\hline Constituent & $\begin{array}{l}\text { Highest } \\
\text { LT-MDL for } \\
\text { October 2009- } \\
\text { March } 2013 \\
\text { ( } \mu \mathrm{g} / \mathrm{L})\end{array}$ & $\begin{array}{l}\text { SRL for } \\
\text { May 2004- } \\
\text { September 2009 } \\
(\mu \mathrm{g} / \mathrm{L})\end{array}$ & $\begin{array}{l}\text { BD-90/90 } \\
\text { concentration for } \\
\text { October 2009- } \\
\text { March } 2013 \\
(\mu \mathrm{g} / \mathrm{L})\end{array}$ & $\begin{array}{c}\text { Updated } \\
\text { SRL starting } \\
\text { October } 2009 \\
\quad(\mu \mathrm{g} / \mathrm{L})\end{array}$ & Basis for selecting the updated SRL \\
\hline Nickel (Ni) & 0.09 & 0.36 & 0.06 & 0.21 & $\begin{array}{l}\text { SRL was updated for nickel from } 0.36 \text { to } 0.21 \mu \mathrm{g} / \mathrm{L} \text { starting October } 2009 \text {, based on } \\
\text { contamination of field blanks and based on positive bias observed in BQS blind blanks. The } \\
\text { SRL is equal to the } 99^{\text {th }} \text { percentile concentration for blind blanks for } 2010 \text {, which is more than } \\
\text { two times the highest LT-MDL concentration in place for nickel during water years } 2010-11 \text {. }\end{array}$ \\
\hline $\begin{array}{l}\text { Selenium } \\
\quad(\mathrm{Se})\end{array}$ & 0.03 & none & - & none & $\begin{array}{l}\text { No SRL was necessary for selenium, based on the low detection frequency and BD-90/90 } \\
\text { calculated from field-blank data. Positive bias was generally low for laboratory blanks and } \\
\text { BQS blind blanks. }\end{array}$ \\
\hline Silver (Ag) & 0.005 & none & - & none & $\begin{array}{l}\text { No SRL was necessary for silver based on the low detection frequency and BD-90/90 calculated } \\
\text { from field-blank data. However, some positive bias was observed in laboratory and BQS blind } \\
\text { blanks: the } 99^{\text {th }} \text { percentile concentrations for laboratory blanks during water year } 2011 \text { and for } \\
\text { blind blanks during } 2013 \text { were greater than the LT-MDL in place for silver. }\end{array}$ \\
\hline $\begin{array}{l}\text { Strontium } \\
\quad(\mathrm{Sr})\end{array}$ & 0.2 & 0.99 & - & none & $\begin{array}{l}\text { SRL was updated for strontium from } 0.99 \mu \mathrm{g} / \mathrm{L} \text { to none starting October } 2009 \text {, based on the low } \\
\text { detection frequency and BD-90/90 calculated from field-blank data. However, some positive } \\
\text { bias was observed in laboratory blanks: the } 99^{\text {th }} \text { percentile concentrations for laboratory blanks } \\
\text { during water years } 2011-12 \text { were greater than the LT-MDL in place for strontium. }\end{array}$ \\
\hline $\begin{array}{l}\text { Thallium } \\
\text { (Tl) }\end{array}$ & 0.010 & none & - & none & $\begin{array}{l}\text { No SRL was necessary for thallium, based on the low detection frequency and BD-90/90 } \\
\text { calculated from field-blank data. Positive bias was generally low for laboratory blanks and } \\
\text { BQS blind blanks. }\end{array}$ \\
\hline $\begin{array}{l}\text { Tungsten } \\
\text { (W) }\end{array}$ & 0.010 & 0.11 & 0.023 & 0.023 & $\begin{array}{l}\text { SRL was updated for tungsten from } 0.11 \text { to } 0.023 \mu \mathrm{g} / \mathrm{L} \text { starting October } 2009 \text {, based on continued } \\
\text { contamination of field blanks, likely due to the equipment and (or) sampling processes. The } \\
\text { SRL is equal to the BD- } 90 / 90 \text { concentration for October } 2009 \text { through March 2013. Positive } \\
\text { bias was generally low for laboratory blanks and BQS blind blanks. }\end{array}$ \\
\hline Uranium $(\mathrm{U})$ & 0.004 & none & - & none & $\begin{array}{l}\text { No SRL was necessary for uranium, based on the low detection frequency and BD-90/90 } \\
\text { calculated from field-blank data. Positive bias was generally low for laboratory blanks and } \\
\text { BQS blind blanks. }\end{array}$ \\
\hline $\begin{array}{l}\text { Vanadium } \\
\text { (V) }\end{array}$ & 0.08 & 0.10 & - & none & $\begin{array}{l}\text { SRL was updated for vanadium from } 0.10 \mu \mathrm{g} / \mathrm{L} \text { to none starting October } 2009 \text {, based on the low } \\
\text { detection frequency and BD-90/90 calculated for field-blank data. However, some positive } \\
\text { bias was observed in laboratory blanks: the } 99^{\text {th }} \text { percentile concentrations for laboratory blanks } \\
\text { during water years } 2010-11 \text { were greater than the LT-MDL in place for vanadium. }\end{array}$ \\
\hline Zinc (Zn) & 1.4 & 4.8 & 6.2 & 6.2 & $\begin{array}{l}\text { SRL was updated for zinc from } 4.8 \text { to } 6.2 \mu \mathrm{g} / \mathrm{L} \text { starting October } 2009 \text {, based on increased } \\
\text { contamination of field blanks likely due to the equipment and (or) sampling process. The SRL } \\
\text { is equal to the BD-90/90 concentration calculated for field blanks collected during October } \\
2009 \text { through March } 2013 \text {. Positive bias was generally low for laboratory blanks and BQS } \\
\text { blind blanks. }\end{array}$ \\
\hline
\end{tabular}


Trace Elements Detected in Fewer Than 5 Percent of Field Blanks (Al, Sb, As, Ba, Be, B, $\mathrm{Cd}, \mathrm{Cr}$, Li, Se, Ag, Sr, TI, U, and V)

Of the 24 trace elements analyzed for samples collected from October 2009 through March 2013 for the GAMA-PBP and NAWQA SOCA, 8 were not detected in any of the field blanks: beryllium, cadmium, lithium, selenium, strontium, thallium, uranium, and vanadium (table $3 \mathrm{~A}$ ). These trace elements were either not detected or were detected in fewer than 5 percent of the field blanks used for the previous review (Olsen and others, 2010). Seven other trace elementsaluminum, antimony, arsenic, barium, boron, chromium, and silver-were detected in fewer than 5 percent of the field blanks collected from October 2009 through March 2013. For a trace element detected in fewer than 5 percent of the 89 field blanks, the BD-90/90 value was a nondetection; therefore, no SRLs were defined for October 2009 through March 2013 for the 15 trace elements detected in fewer than 5 percent of the field blanks.

\section{Aluminum (Al)}

From March 2006 through September 2009, 4 of 90 field blanks (4.4 percent) collected for aluminum had detections (fig. 3A; table 3A). Three of the detected concentrations were in the range of 1.0 to $1.8 \mu \mathrm{g} / \mathrm{L}$; the fourth detected concentration was $4.0 \mu \mathrm{g} / \mathrm{L}$, and aluminum was detected at $4.2 \mu \mathrm{g} / \mathrm{L}$ in the associated source-solution blank collected just prior to that field blank. A source-solution blank collected 1 month later for the same lot of blank water had an aluminum concentration of $3.9 \mu \mathrm{g} / \mathrm{L}$, but aluminum was not detected in the field blank collected immediately after that sourcesolution blank. Olsen and others (2010) reported detections of aluminum in source-solution and field blanks, as well as several detections reported in the BQS-BBP data. The SRL was set at $1.6 \mu \mathrm{g} / \mathrm{L}$, equal to twice the LT-MDL concentration for 2004-08; however, since then, the LT-MDL for aluminum has increased to $2.2 \mu \mathrm{g} / \mathrm{L}$.

From October 2009 through March 2013, 1 of 89 field blanks (1.1 percent) collected for aluminum had a detection. This detected concentration, $30 \mu \mathrm{g} / \mathrm{L}$, was more than 10 times greater than the highest LT-MDL $(2.2 \mu \mathrm{g} / \mathrm{L})$ and greater than the detected concentration in the subsequently collected groundwater sample $(7.9 \mu \mathrm{g} / \mathrm{L})$. A source-solution blank collected 5 months prior using the same lot of IBW did not have an aluminum detection. The aluminum detections in field and source-solution blanks do not show a temporal trend or pattern in concentration or sample type. Additionally, variation or positive bias was not observed in internal laboratory blanks. For laboratory blanks analyzed October 2009 through March 2013, the mean was $0 \mu \mathrm{g} / \mathrm{L}$ (standard deviation = $0.15 \mu \mathrm{g} / \mathrm{L}$ ); the highest $99^{\text {th }}$ percentile concentration for laboratory blanks for water years $2010-12$ was $0.88 \mu \mathrm{g} / \mathrm{L}$ (tables 4- ).

During January 2011 through August 2012, BQS summaries reported intermittent positive bias and variation for aluminum analyses observed in BBP and IBSP samples (Struzeski, variously dated). Bias and contamination were attributed to persistent instrument contamination, calibration standards, and mispours. The $99^{\text {th }}$ percentiles of blindblank concentrations for water years 2010, 2011, and 2012 for aluminum were 3.6, 4.7, and $12.7 \mu \mathrm{g} / \mathrm{L}$, respectively, compared to the highest LT-MDL for October 2009 through March 2013, which was $2.2 \mu \mathrm{g} / \mathrm{L}$ (table 5). Although the blind blanks indicated potential QA issues for aluminum, contamination bias was not observed in most of the laboratory, source-solution, and field blanks. Based on the field blanks collected during October 2009 through March 2013, an upper limit of contamination bias could not be determined for groundwater samples collected by the GAMA-PBP. Therefore, the SRL for aluminum was updated from 1.6 to "none" starting October 2009 (table 6). 


\section{$\boldsymbol{A}$}

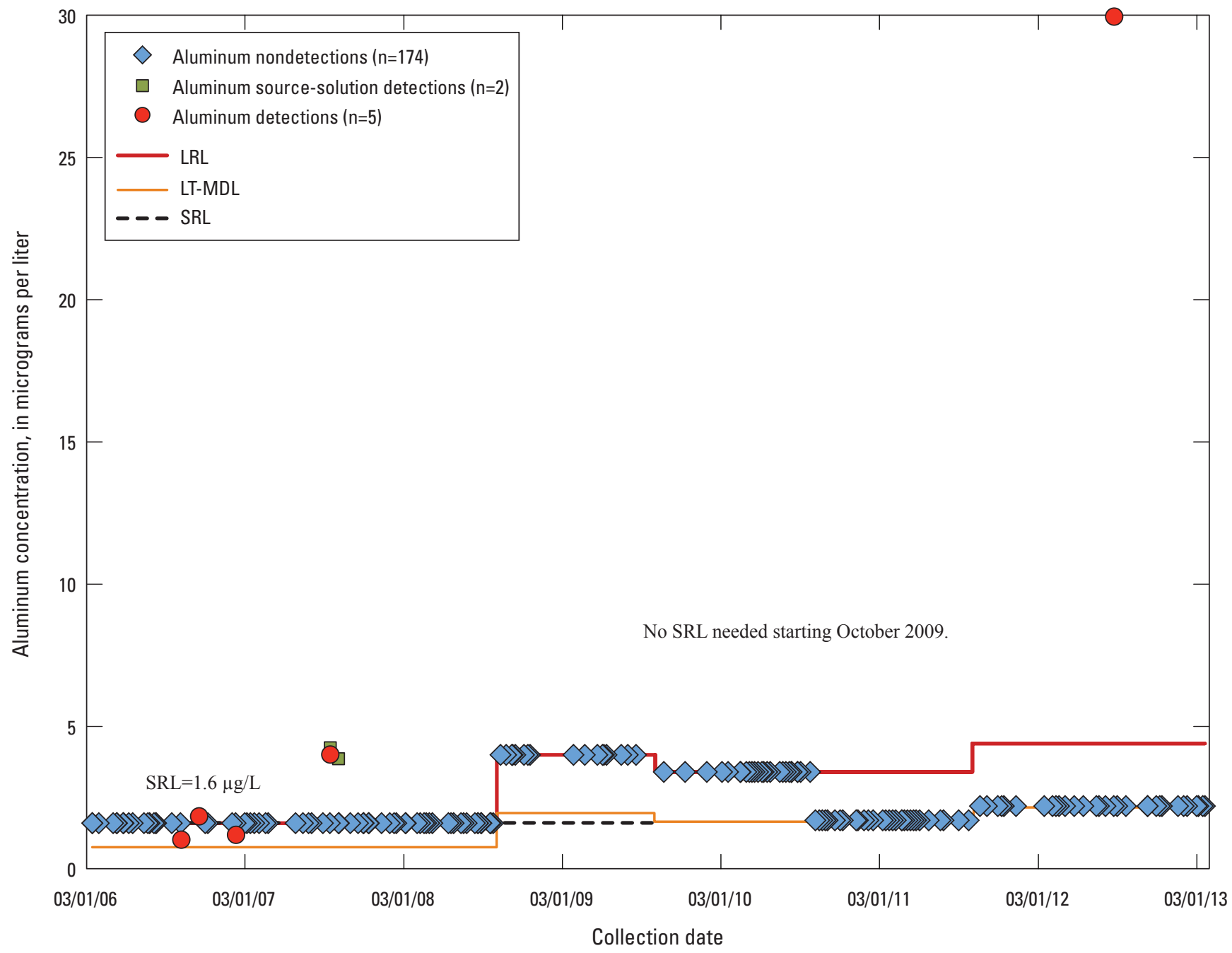

Figure 3. Trace-element concentrations, study reporting levels (SRLs), laboratory reporting levels (LRLs), and long-term method detection levels (LT-MDLs) for constituents detected in fewer than 5 percent of the field blanks collected from 0ctober 2009 through March 2013, Groundwater Ambient Monitoring and Assessment (GAMA) Priority Basin Project: $(A)$ aluminum, $(B)$ antimony, $(C)$ arsenic, $(D)$ barium, $(E)$ beryllium, $(F)$ boron, $(G)$ cadmium, $(H)$ chromium, (I) lithium, $(J)$ selenium, $(K)$ silver, $(L)$ strontium, $(M)$ thallium, $(M)$ uranium, and $(0)$ vanadium. $[\mu \mathrm{g} / \mathrm{L}$, micrograms per liter] 


\section{Antimony (Sb)}

From March 2006 through September 2009, none of the 90 field blanks collected for antimony had a detection (fig. 3B; table 3A). From October 2009 through March 2013, 1 of 89 field blanks (1.1 percent) collected for antimony had a detection. The detected concentration, $0.14 \mu \mathrm{g} / \mathrm{L}$, was more than five times the LT-MDL that was in place when the sample was collected in $2013(0.027 \mu \mathrm{g} / \mathrm{L})$. Antimony was not detected in any of the 38 source-solution blanks, and the laboratory and blind-blank data did not show significant bias or variation (tables 4- ). Therefore, the SRL for antimony was not updated from the previous SRL of "none" (table 6).

B

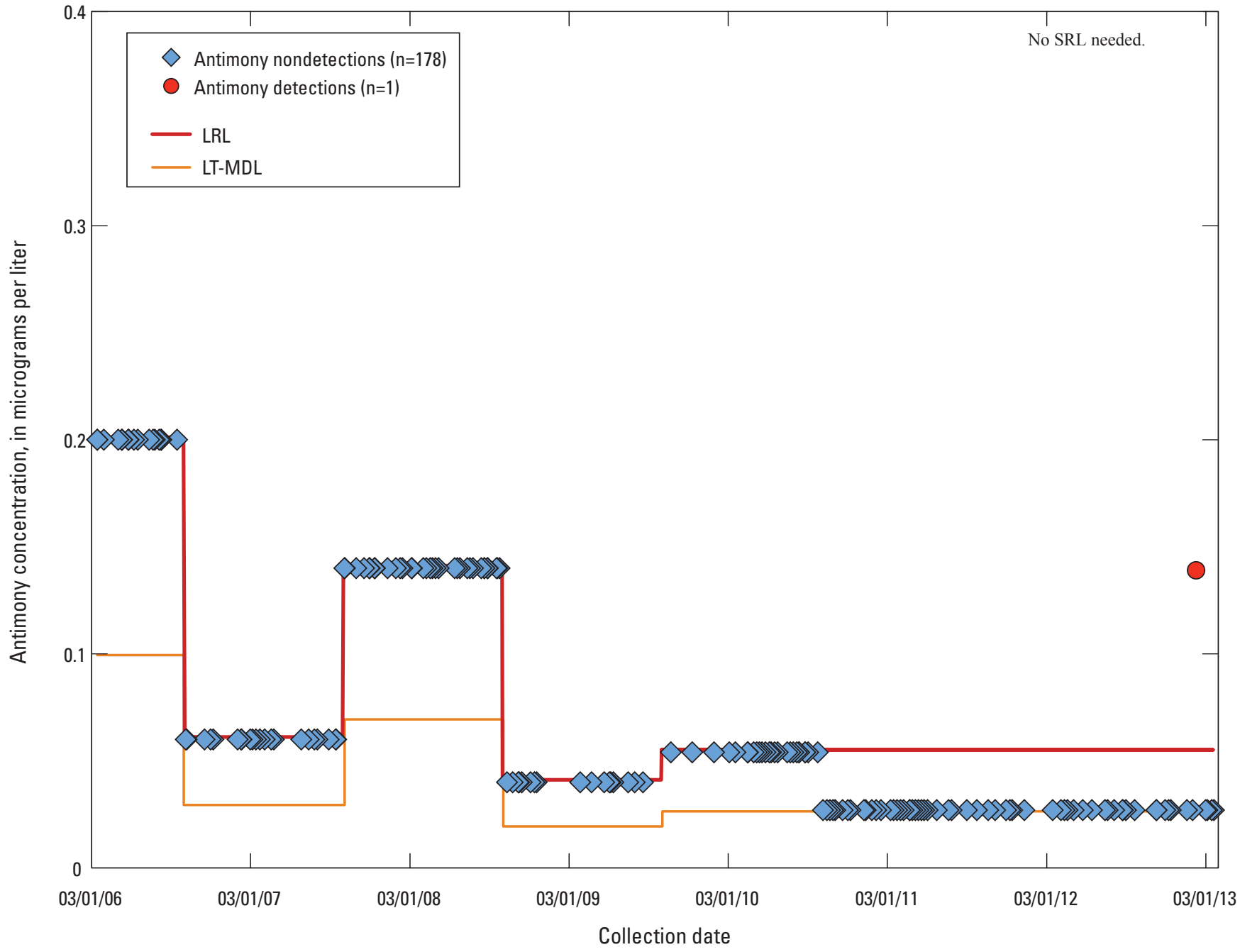

Figure 3. - Continued 


\section{Arsenic (As)}

From March 2006 through September 2009, none of the 90 field blanks collected for arsenic had a detection (fig. 3C; table 3A). From October 2009 through March 2013, 2 of the 89 field blanks (2.2 percent) collected for arsenic had detections. Detected concentrations were 0.050 and $0.036 \mu \mathrm{g} / \mathrm{L}$; only one of these concentrations $(0.050 \mu \mathrm{g} / \mathrm{L})$ was greater than two times the LT-MDL $(0.022 \mu \mathrm{g} / \mathrm{L})$ used by the NWQL at the time the sample was collected (fig. 3C). Arsenic was not detected in any of the 38 source-solution blanks. Laboratory-blank results reported by the NWQL showed some slight variation: for October 2009 through March 2013, the standard deviation $(0.019 \mu \mathrm{g} / \mathrm{L})$ almost doubled from the standard deviation $(0.01 \mu \mathrm{g} / \mathrm{L})$ for previous time period, March 2006 through September 2009 (table 4). Additionally, BQS results indicate that $99^{\text {th }}$ percentile concentrations and calculated LT-MDLs for BQS blind blanks and $99^{\text {th }}$ percentile concentrations for NWQL internal laboratory blanks were consistently greater than the LT-MDLs in place for water years 2010-13 (table 5). Laboratory-blank and blind-blank results indicate that caution should be used when interpreting groundwater concentrations for arsenic near the LT-MDL, yet establishing an SRL was not necessary based on field-blank results. Therefore, the SRL for arsenic was not updated from the previous SRL of "none" (table 6 ).

C

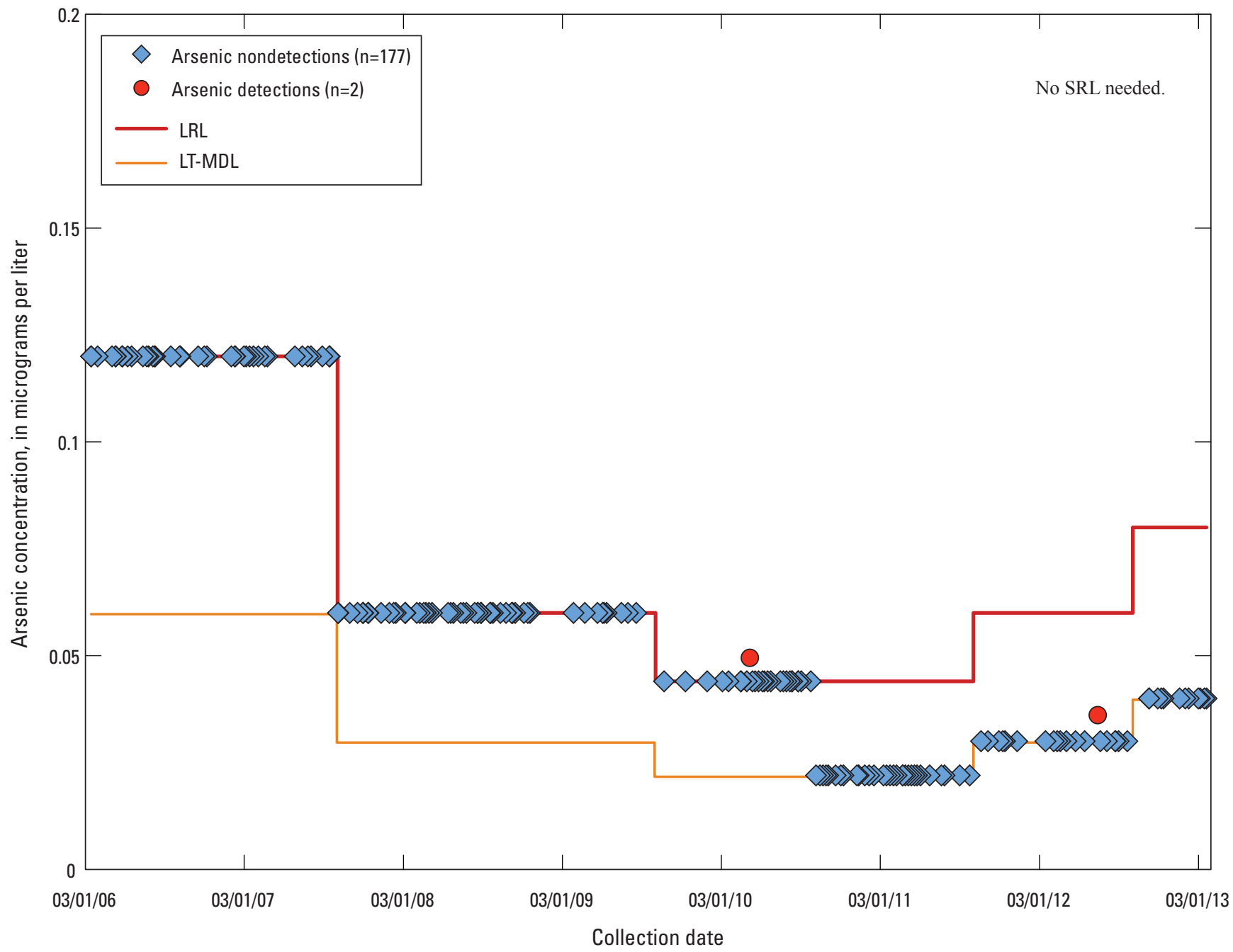

Figure 3. - Continued 


\section{Barium (Ba)}

From March 2006 through September 2009, 4 of the 90 field blanks ( 4.4 percent) collected for barium had detections (fig. 3D; table 3A). From October 2009 through March 2013, 2 of the 89 field blanks (2.2 percent) collected for barium had detections; both of these field blanks were collected in 2011. The detected concentrations, 0.073 and $0.121 \mu \mathrm{g} / \mathrm{L}$, were near the LT-MDL in place at the time $(0.07 \mu \mathrm{g} / \mathrm{L})$ (fig. $3 D)$. One of the 38 source-solution blanks had a barium detection; the sample was collected in 2011 using the same lot of blank water as was used to collect the field blanks with detections and had a detected concentration of $0.162 \mu \mathrm{g} / \mathrm{L}$. Barium was not detected in the field blank collected immediately after the source-solution blank with the detection nor in any of the three other source-solution blanks collected in 2011 with the same lot of blank water.
Laboratory-blank results reported by the NWQL did not show significant variation during March 2006 through March 2013 (table 4). However, the $99^{\text {th }}$ percentile concentrations for laboratory blanks for water year 2011 and BQS blind blanks for 2011-13 were greater than the LT-MDLs in place for barium (table 5). The consistent bias observed in blind-blank results indicates that caution should be used when interpreting groundwater concentrations for barium near the LT-MDL, yet establishing an SRL was not necessary based on field-blank results. Therefore, the SRL for barium was updated from $0.36 \mu \mathrm{g} / \mathrm{L}$ to "none" starting October 2009 (table 6).

D

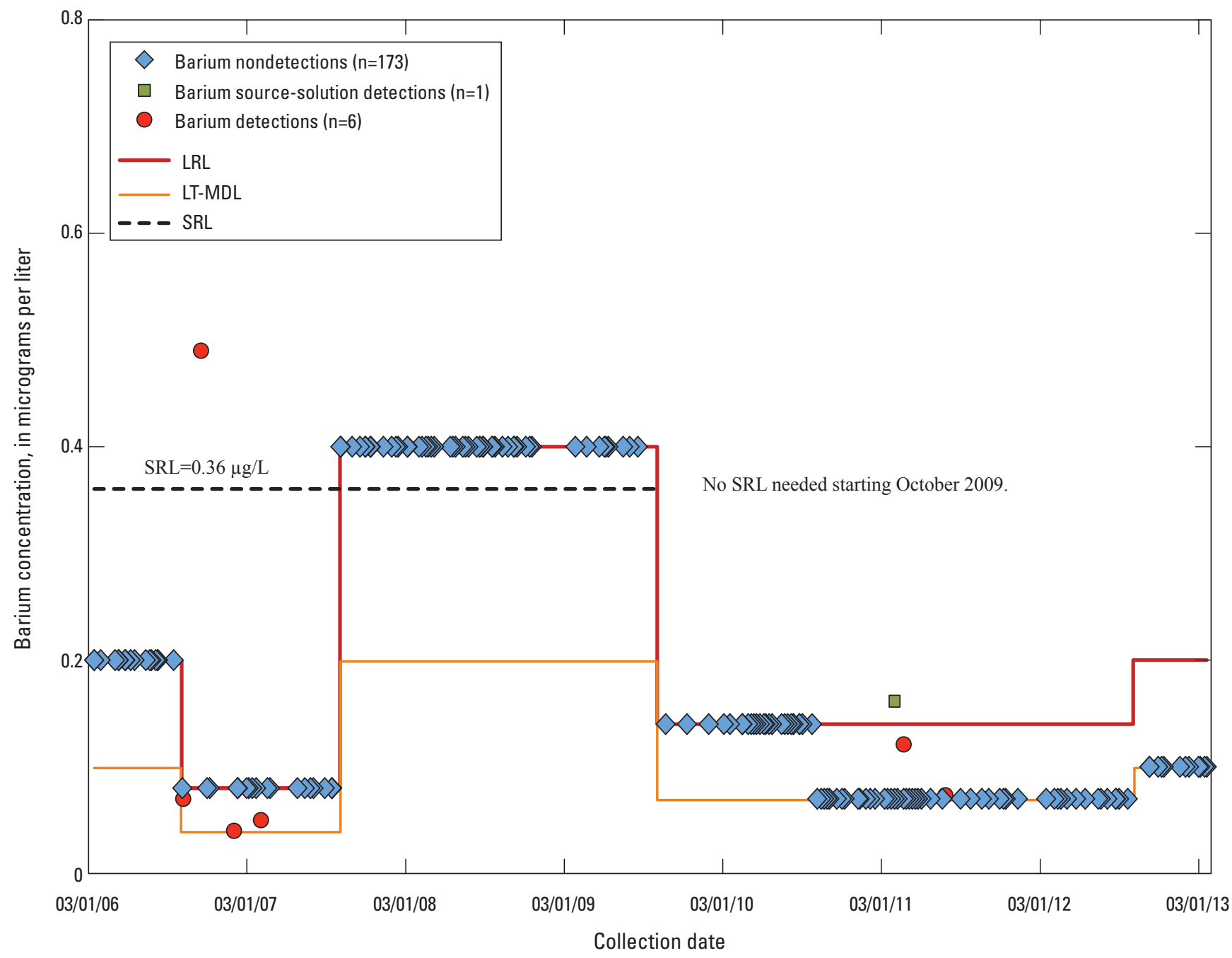

Figure 3. - Continued 


\section{Beryllium (Be)}

From March 2006 through March 2013, none of the 179 field blanks collected for beryllium had a detection (fig. 3E; table 3A). Beryllium was not detected in any of the 38 source-solution blanks, and the internal and BQS QC data did not indicate any systematic laboratory contamination for beryllium (tables 4-5). Therefore, the SRL for beryllium was not updated from the previous SRL of "none" (table 6).

$\boldsymbol{E}$

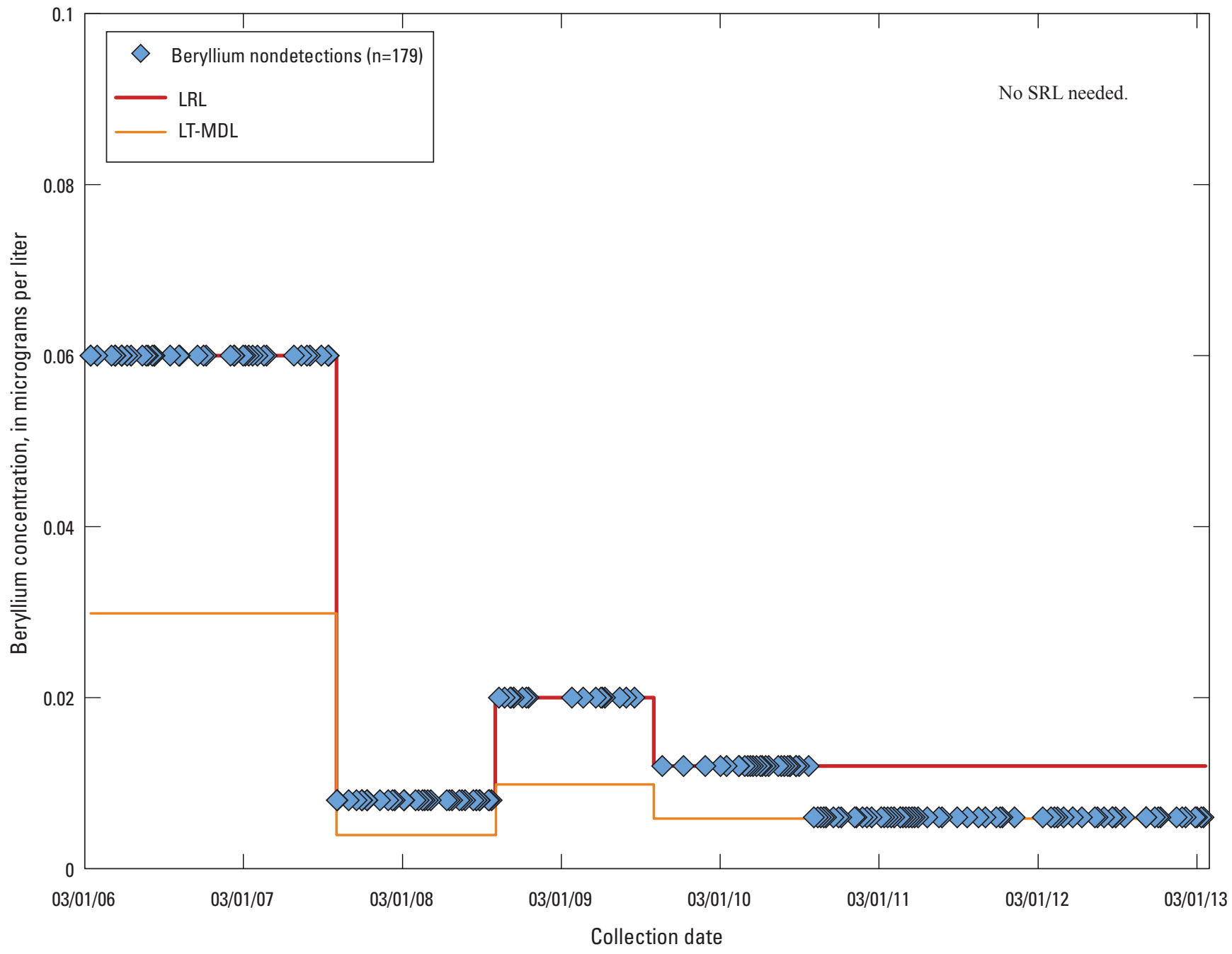

Figure 3. - Continued 


\section{Boron (B)}

From March 2006 through September 2009, 4 of the 90 field blanks (4.4 percent) collected for boron had detections (fig. 3F; table 3A). From October 2009 through March 2013, 4 of the 89 field blanks (4.5 percent) collected for boron had detections. The concentrations for the eight detections were in the range of 19.4 to $32.5 \mu \mathrm{g} / \mathrm{L}$. Two lots of IBW were used to collect the field blanks that had boron detections: NWQL lot number 80703 for detections in samples collected in 2007 and 2008 and NWQL lot number 81202 for detections in samples collected in 2012. A source-solution blank collected in 2007 for the 80703 lot had a detection of boron of $23.5 \mu \mathrm{g} / \mathrm{L}$. As discussed by Olsen and others (2010), the IBW was identified as the source of the boron contamination in the samples collected with that lot of blank water. No source-solution blank was collected for the 81202 lot; however, the NWQL reported in the certificate of analysis for that IBW that the water contained boron at concentrations up to $30 \mu \mathrm{g} / \mathrm{L}$ (James A. Lewis, National Water Quality Laboratory, written commun., September 2012). Laboratory-blank and BQS blind-blank results did not show significant variation or bias (tables 4- ). Therefore the SRL for boron was not updated from the previous SRL of "none" (table 6 ).

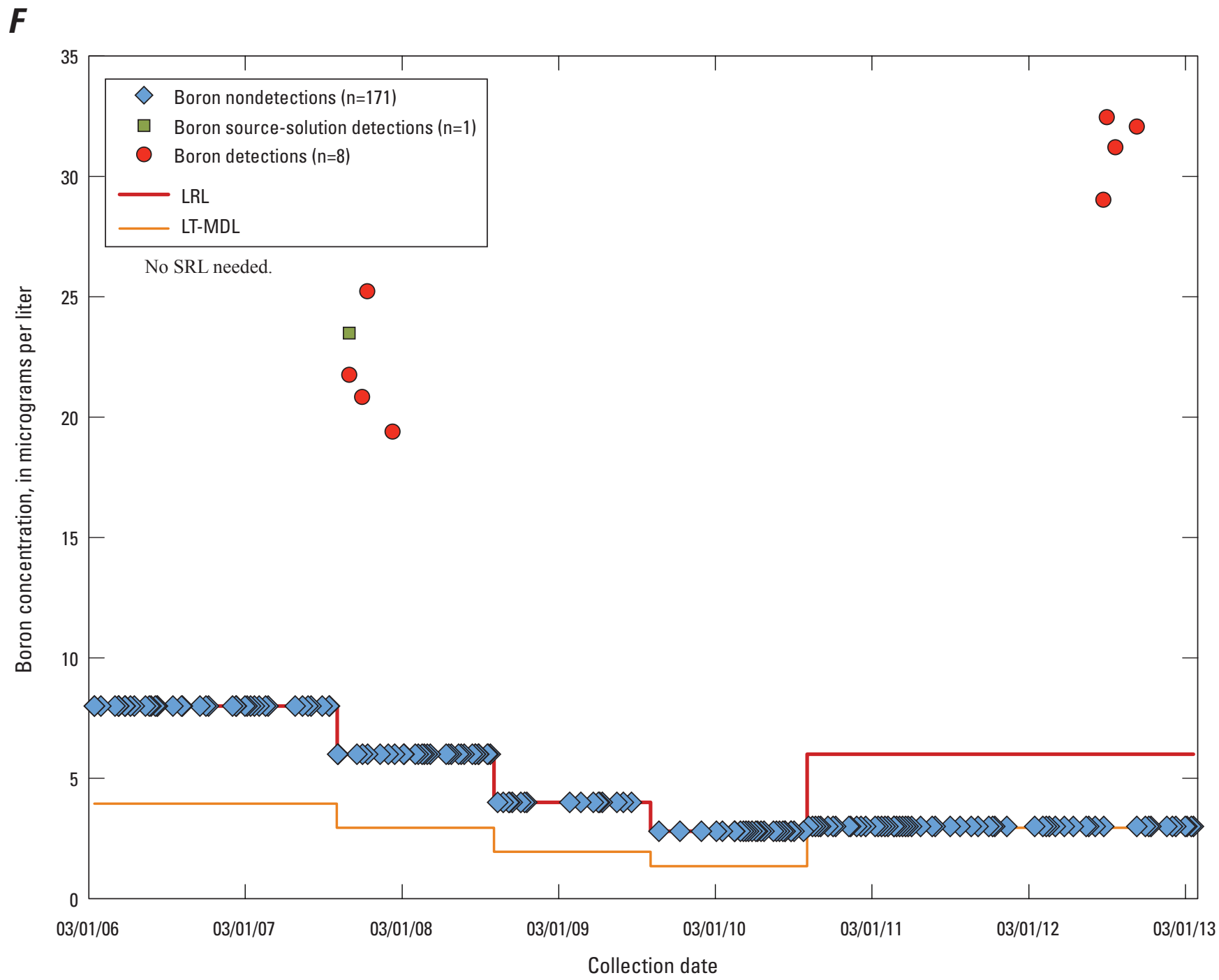

Figure 3. - Continued 


\section{Cadmium (Cd)}

From March 2006 through September 2009, 1 of the 90 field blanks (1.1 percent) collected for cadmium had a detection (fig. 3G; table 3A). The detected concentration, $0.027 \mu \mathrm{g} / \mathrm{L}$, was almost three times the LT-MDL that was in place when the sample was collected in $2008(0.010 \mu \mathrm{g} / \mathrm{L})$. From October 2009 through March 2013, none of the 89 field blanks collected for cadmium had a detection. Cadmium was not detected in any of the 38 source-solution blanks, and the BQS or internal QC data did not indicate any systematic laboratory contamination for cadmium (tables 4- 5 ). Therefore, the SRL for cadmium was not updated from the previous SRL of "none" (table 6).

G

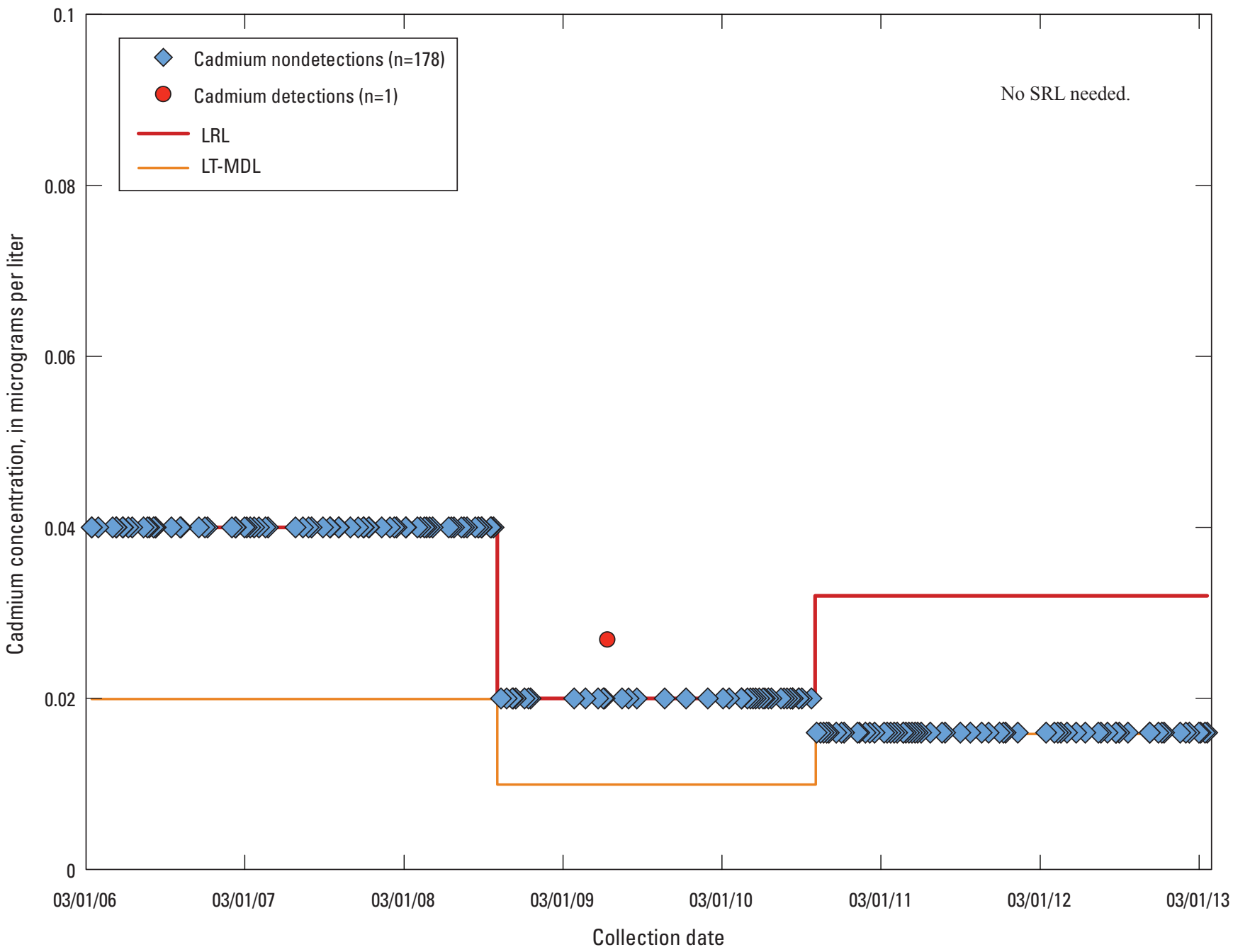

Figure 3. - Continued 


\section{Chromium (Cr)}

From March 2006 through September 2009, 14 of the 90 field blanks (16 percent) collected for chromium had detections (fig. $3 H$; table 3A). The detected concentrations were in the range of 0.02 to $0.15 \mu \mathrm{g} / \mathrm{L}$. Eleven of the 14 detections in field blanks occurred prior to the increase of the LT-MDL concentration in October 2006 from 0.02 to $0.06 \mu \mathrm{g} / \mathrm{L}$, and 8 of those detections were at concentrations less than $0.06 \mu \mathrm{g} / \mathrm{L}$. There was only one detected concentration $(0.15 \mu \mathrm{g} / \mathrm{L})$ that was greater than twice the LT-MDL in place when the sample was collected $(0.06 \mu \mathrm{g} / \mathrm{L})$ in 2008. From October 2009 through March 2013, 1 of the 89 field blanks (1.1 percent) collected for chromium had a detection. The detected concentration, $0.08 \mu \mathrm{g} / \mathrm{L}$, was just above the LT-MDL of $0.07 \mu \mathrm{g} / \mathrm{L}$. Chromium was not detected in any of the 38 source-solution blanks.

The SRL determined by Olsen and others (2010) for samples collected during May 2004 through January 2008 was $0.42 \mu \mathrm{g} / \mathrm{L}$. The BD-90/90 had been calculated based on results that were not included in the dataset evaluated for the present study. These results included blanks collected with UBW known to have chromium concentrations up to $0.83 \mu \mathrm{g} / \mathrm{L}$, a field blank collected by using monitoring-well equipment with known chromium contamination (Bennett and others, 2009), and a field blank with detections of 17 inorganics which was anomalous to typical field-blank results (Densmore and others, 2009).

Laboratory-blank results reported by the NWQL showed some slight variation: for October 2009 through March 2013, the standard deviation $(0.04 \mu \mathrm{g} / \mathrm{L})$ doubled from the standard deviation $(0.02 \mu \mathrm{g} / \mathrm{L})$ for previous time period, March 2006 through September 2009 (table 4). The $99^{\text {th }}$ percentile concentrations for BQS blind blanks and (or) laboratory blanks were greater than the LT-MDLs in place for chromium for water years 2011-13 (table 5). Laboratory-blank and blind-blank results indicate that caution should be used when interpreting groundwater concentrations for chromium near the LT-MDL, yet establishing an SRL was not necessary based on field-blank results. Therefore, the SRL for chromium was updated from $0.42 \mu \mathrm{g} / \mathrm{L}$ to "none" starting October 2009 (table 6).

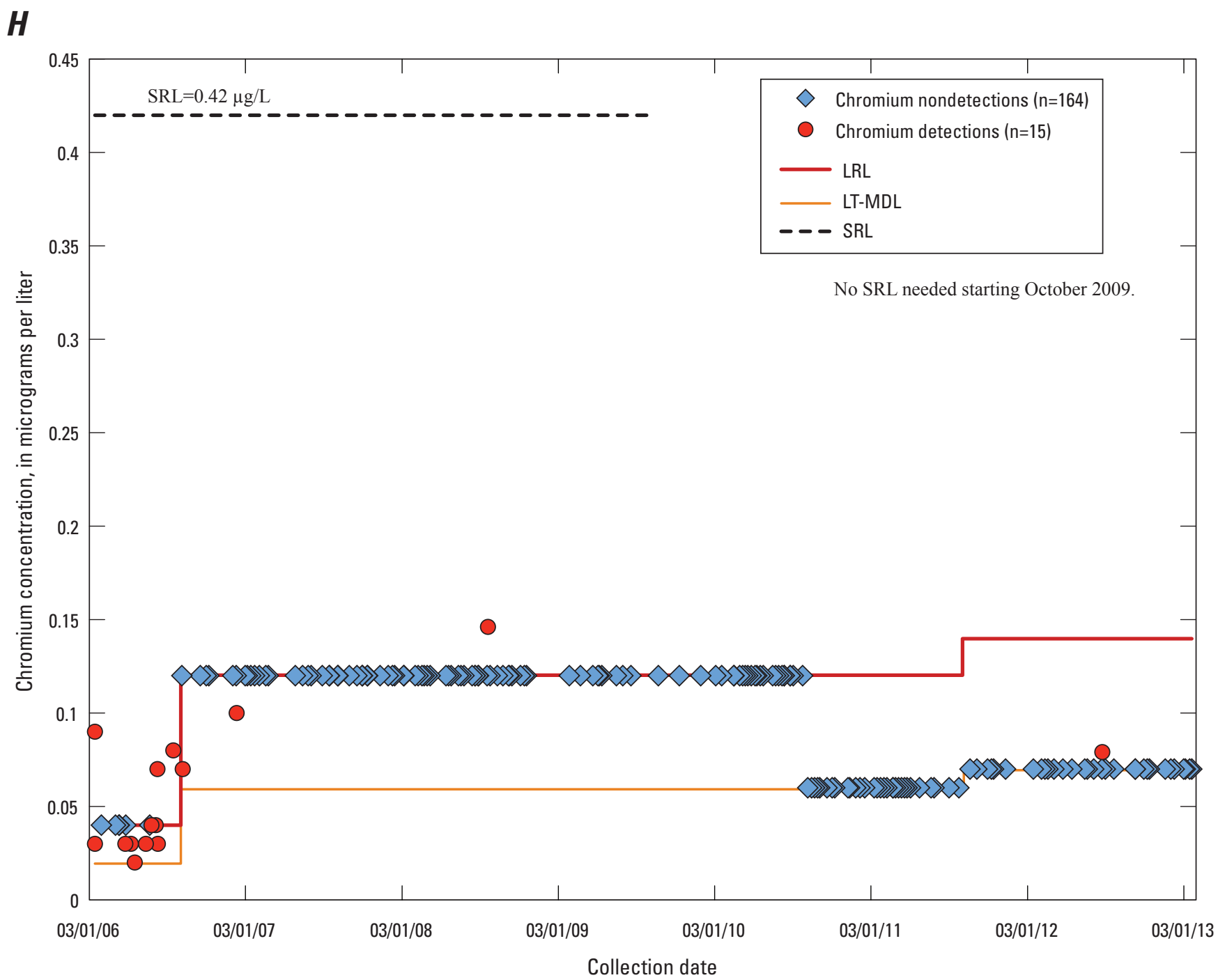

Figure 3. - Continued 


\section{Lithium (Li)}

From March 2006 through March 2013, none of the 179 field blanks collected for lithium had a detection (fig. 3I; table 3A). Lithium was not detected in any of the 38 sourcesolution blanks, and the internal and BQS QC data did not indicate any systematic laboratory contamination for lithium (tables 4- ). Therefore, the SRL for lithium was not updated from the previous SRL of "none" (table 6).

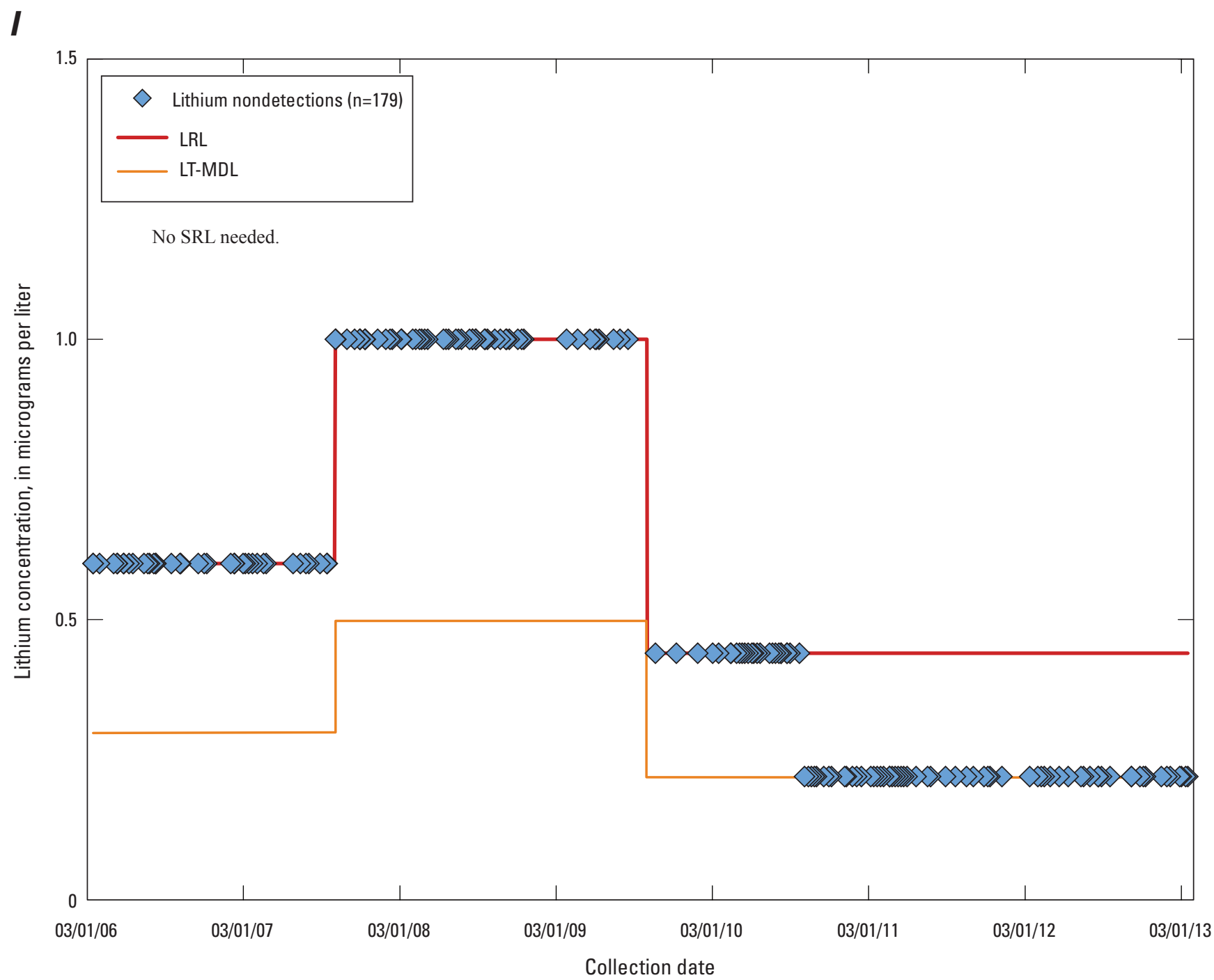

Figure 3. -Continued 


\section{Selenium (Se)}

From March 2006 through March 2013, none of the 179 field blanks collected for selenium had a detection (fig. 3J; table 3A). Selenium was not detected in any of the 38 sourcesolution blanks, and the internal and BQS QC data did not indicate any systematic laboratory contamination for selenium (tables 4-5). Therefore, the SRL for selenium was not updated from the previous SRL of "none" (table 6).

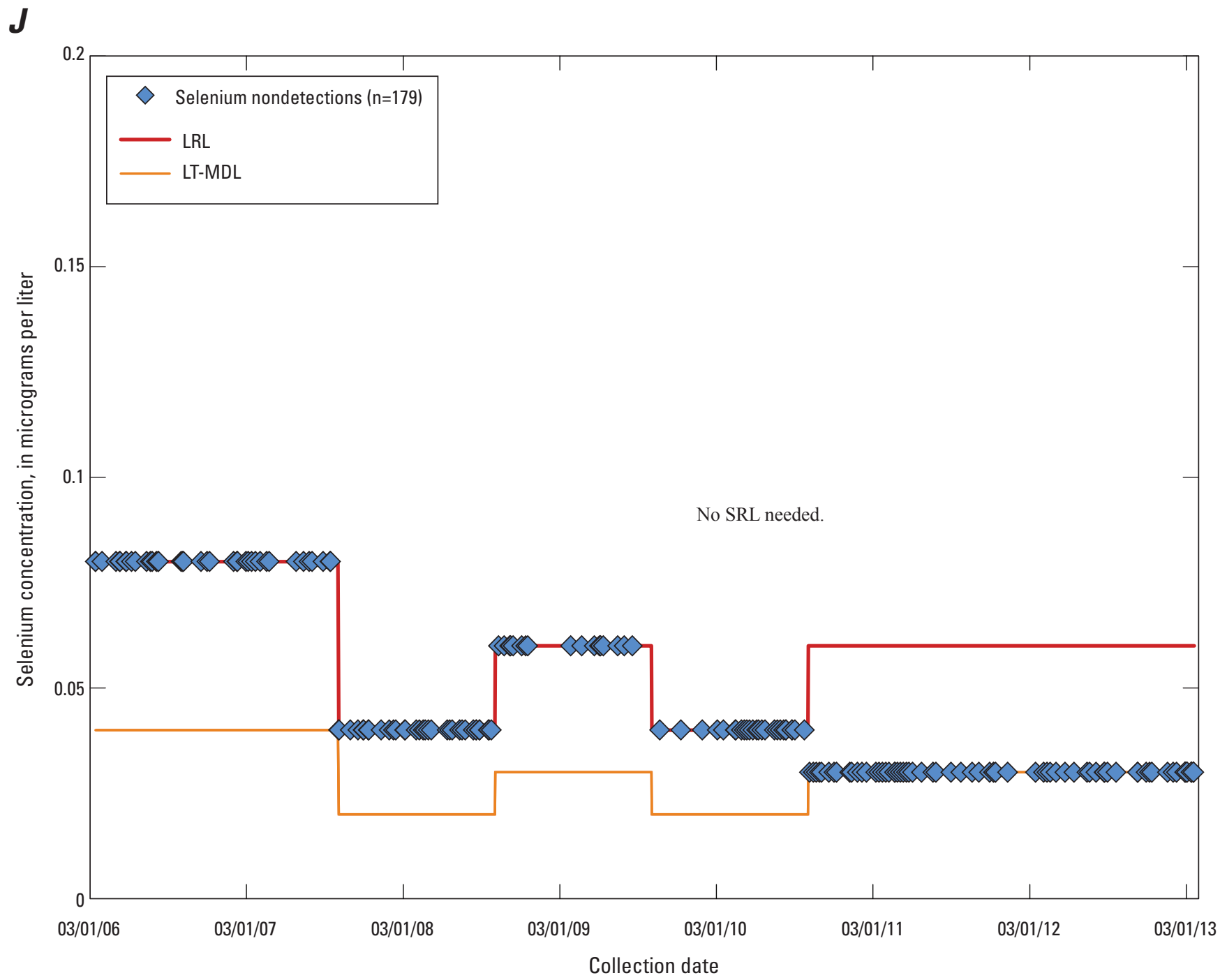

Figure 3. - Continued 


\section{Silver $(\mathrm{Ag})$}

From March 2006 through September 2009, 2 of the 90 field blanks (2.2 percent) collected for silver had detections (fig. 3K; table 3A). Detected concentrations were $0.19 \mu \mathrm{g} / \mathrm{L}$ and $1.08 \mu \mathrm{g} / \mathrm{L}$ in samples collected in 2006 and 2008, respectively. The source-solution blank collected prior to the 2008 field blank had a silver concentration of $1.04 \mu \mathrm{g} / \mathrm{L}$. Fourteen field blanks and two source-solution blanks were collected with the same lot of IBW, and silver was not detected in those additional blanks. From October 2009 through March 2013, silver was detected in 1 of the 89 field blanks (1.1 percent) at a concentration of $0.007 \mu \mathrm{g} / \mathrm{L}$, just above the LT-MDL of $0.005 \mu \mathrm{g} / \mathrm{L}$. Variation in results for internal laboratory QC decreased by an order of magnitude, as shown by a standard deviation for laboratory blanks of $0.002 \mu \mathrm{g} / \mathrm{L}$ (mean $=0 \mu \mathrm{g} / \mathrm{L}$ ) for October 2009 through March 2013, compared to March 2006 through September 2009 (standard deviation $=0.022 \mu \mathrm{g} / \mathrm{L}$, mean $=0 \mu \mathrm{g} / \mathrm{L})($ table 4$)$. The $99^{\text {th }}$ percentile concentrations for laboratory blanks for 2011 and for BQS blind blanks for $2013(0.006 \mu \mathrm{g} / \mathrm{L}$ for each) were just above the LT-MDL $(0.005 \mu \mathrm{g} / \mathrm{L})$ in place for silver (table 5). These results possibly indicate low-level contamination of silver near the detection level; however, establishing an SRL was not necessary based on field-blank results. Therefore, the SRL for silver was not updated from the previous SRL of "none" (table 6).

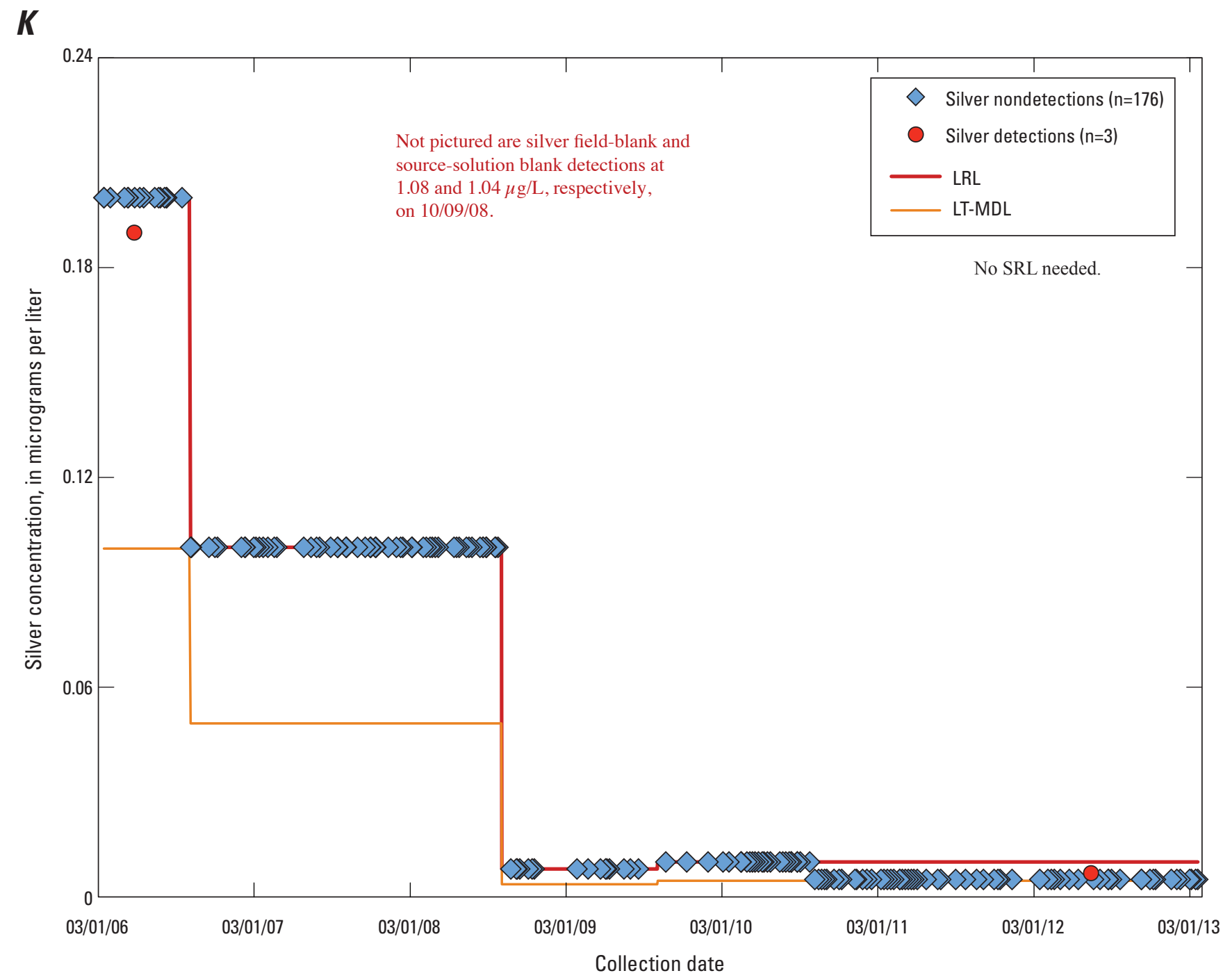

Figure 3. - Continued 


\section{Strontium (Sr)}

From March 2006 through September 2009, 1 of the 90 field blanks (1.1 percent) collected for strontium had a detection (fig. 3L; table 3A). The detected concentration $(0.32 \mu \mathrm{g} / \mathrm{L})$ was near the LT-MDL $(0.20 \mu \mathrm{g} / \mathrm{L})$ in place for strontium during water year 2007 (fig. 3L). From October 2009 through March 2013, none of the 89 field blanks collected for strontium had a detection. Strontium was not detected in any of the 38 source-solution blanks.

The SRL determined by Olsen and others (2010) for samples collected May 2004 through January 2008 was $0.99 \mu \mathrm{g} / \mathrm{L}$. The BD-90/90 had been calculated based on results that were not included in the dataset evaluated for the present study. These results included field blanks collected with UBW known to have strontium concentrations up to $1.43 \mu \mathrm{g} / \mathrm{L}$, a field blank collected by using monitoring-well equipment with known trace-element contamination (Bennett and others, 2009), and a field blank with detections of 17 inorganics which is anomalous to typical field-blank results (Densmore and others, 2009).

Laboratory-blank results reported by the NWQL did not show significant variation (table 4); however, the $99^{\text {th }}$ percentile concentrations calculated by the BQS for laboratory blanks were greater than the LT-MDL $(0.2 \mu \mathrm{g} / \mathrm{L})$ in place for strontium for water years 2011-12 (table 5). For 2011, the $99^{\text {th }}$ percentile concentration $(0.53 \mu \mathrm{g} / \mathrm{L})$ was more than two times the LT-MDL. These results possibly indicate contamination of strontium in laboratory blanks during that time, yet, establishing an SRL was not necessary based on field-blank results. Therefore, the SRL for strontium was updated from $0.99 \mu \mathrm{g} / \mathrm{L}$ to "none" starting October 2009 (table 6).

L

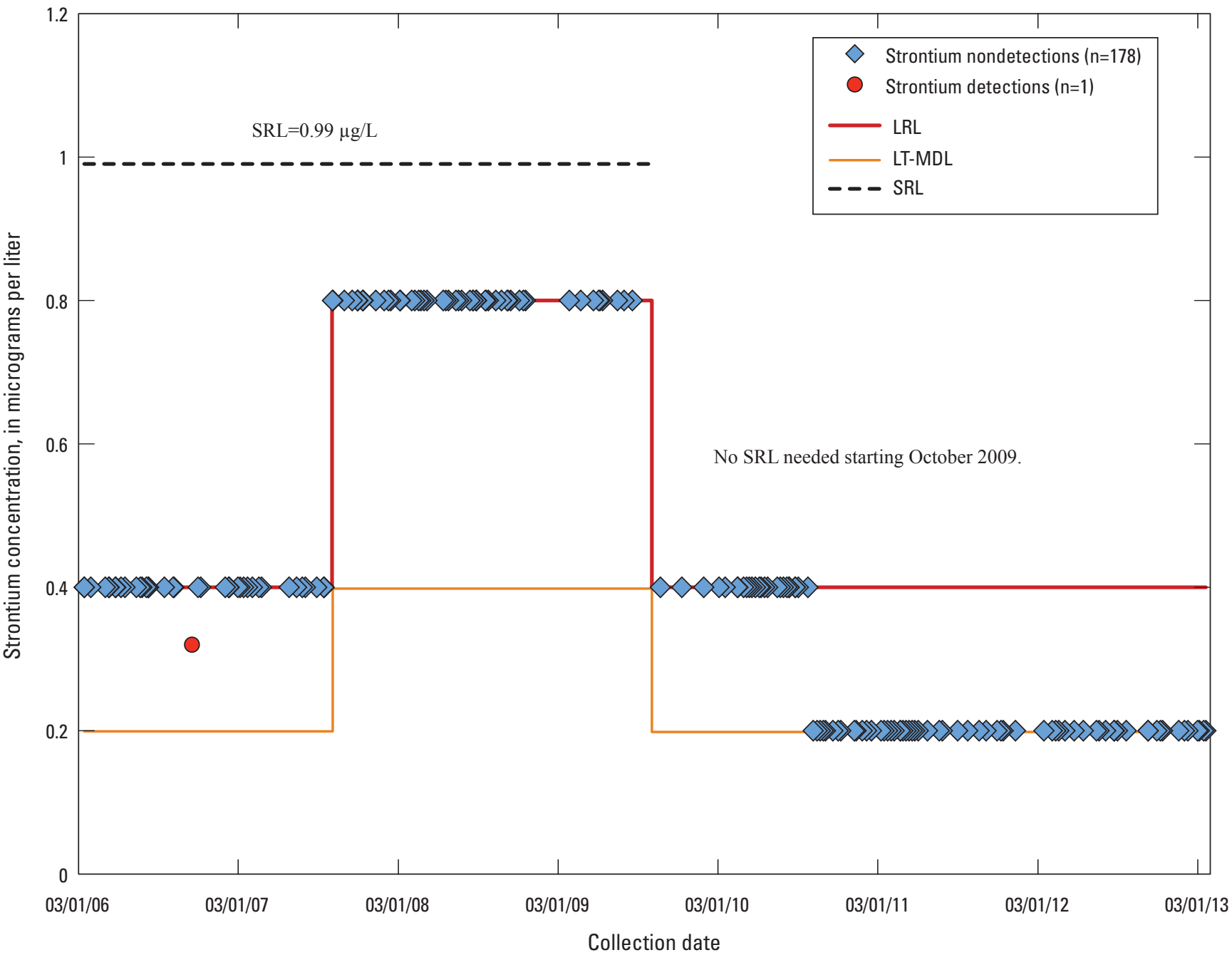

Figure 3. - Continued 


\section{Thallium (TI)}

From March 2006 through September 2009, 1 of 90 field blanks (1.1 percent) collected for thallium had a detection (fig. 3M; table 3A). The detected concentration, $0.021 \mu \mathrm{g} / \mathrm{L}$, was just above the LT-MDL that was in place when the sample was collected in $2006(0.020 \mu \mathrm{g} / \mathrm{L})$. From October 2009 through March 2013, none of the 89 field blanks collected for thallium had a detection. Thallium was not detected in any of the 38 source-solution blanks, and the internal and BQS QC data did not indicate any systematic laboratory contamination for thallium (tables 4- ). Therefore, the SRL for thallium was not updated from the previous SRL of "none" (table 6).

M

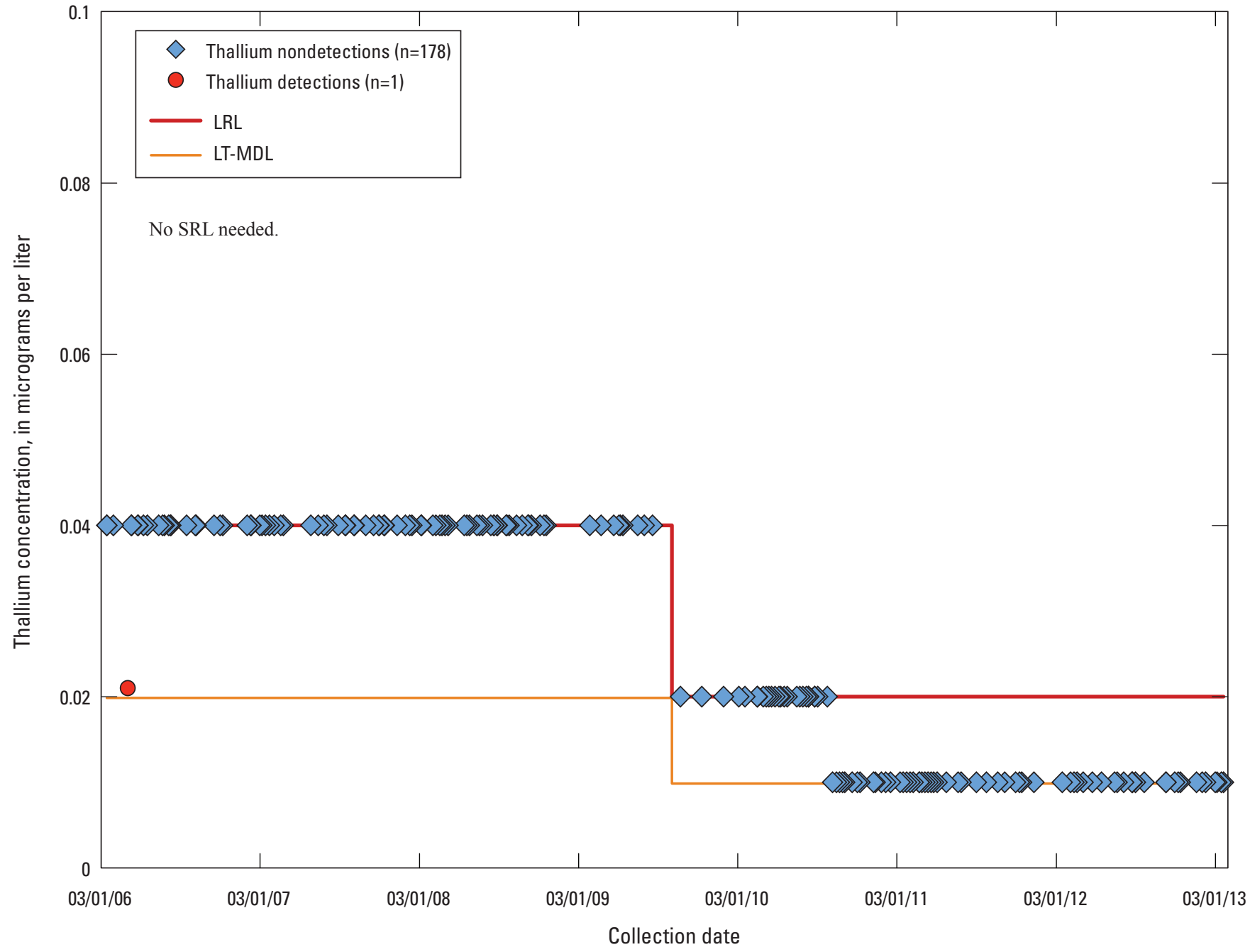

Figure 3. - Continued 


\section{Uranium (U)}

From March 2006 through September 2009, 1 of 90 field blanks (1.1 percent) collected for uranium had a detection (fig. $3 N$; table 3A). The detected concentration, $0.027 \mu \mathrm{g} / \mathrm{L}$, was above the LT-MDL that was in place when the sample was collected in $2006(0.020 \mu \mathrm{g} / \mathrm{L})$. From October 2009 through March 2013, none of the 89 field blanks collected for uranium had a detection. Uranium was not detected in any of the 38 source-solution blanks, and the internal and BQS QC data did not indicate any systematic laboratory contamination for uranium (tables 4- 5 ). Therefore, the SRL for uranium was not updated from the previous SRL of "none" (table 6).

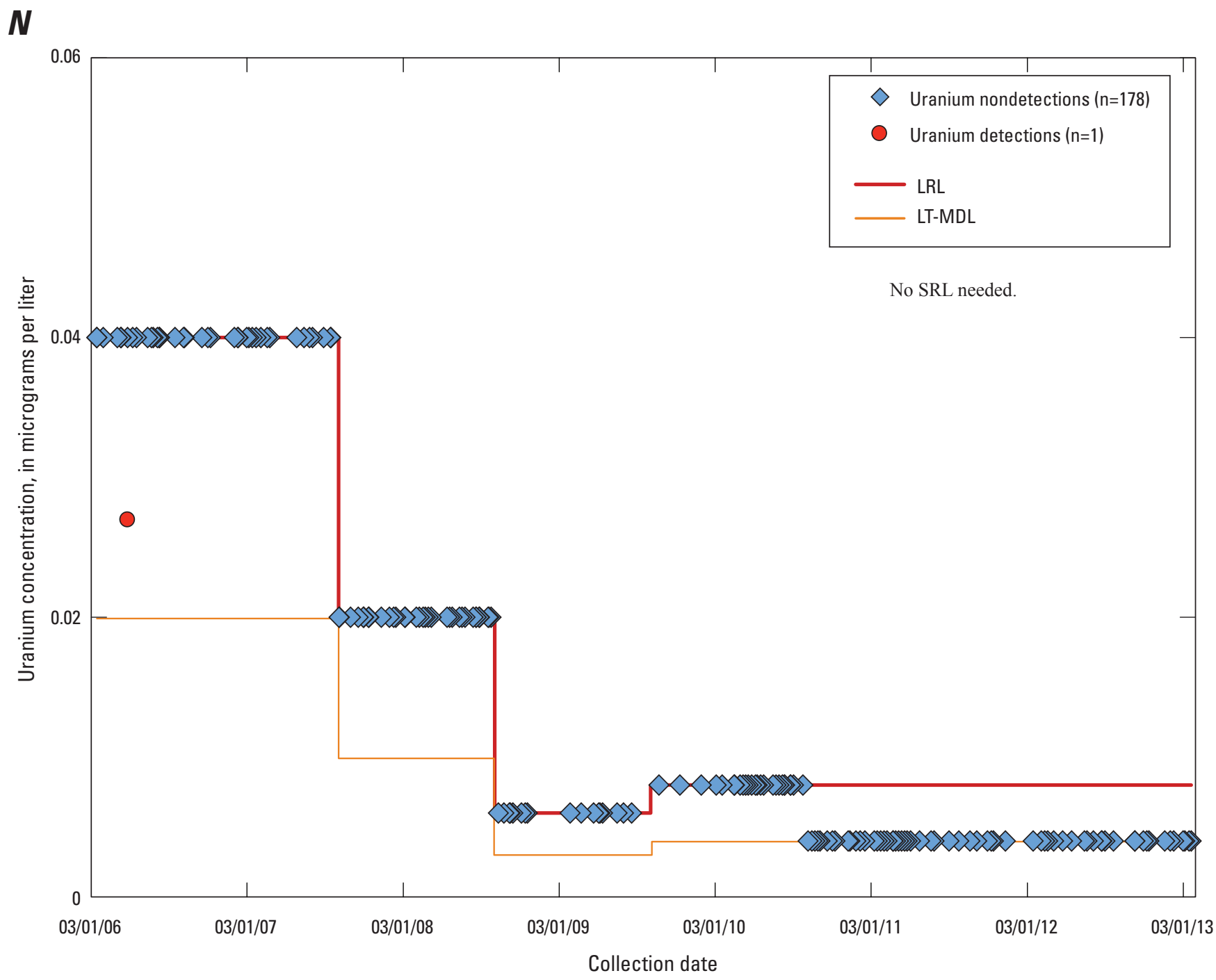

Figure 3. - Continued 


\section{Vanadium (V)}

From March 2006 through March 2013, none of 179 field blanks collected for vanadium had a detection (fig. 3O; table 3A). Vanadium was not detected in any of the 38 sourcesolution blanks. The SRL determined by Olsen and others (2010) for samples collected May 2004 through January 2008 was $0.10 \mu \mathrm{g} / \mathrm{L}$. The BD-90/90 had been calculated based on results that were not included in the dataset used in the present study. These results included blanks collected with UBW or OBW, field blanks collected by using monitoring-well equipment, and a field blank with detections of 17 inorganics which is anomalous to typical field-blank results (Densmore and others, 2009). In fact, seven of the nine field-blank detections of vanadium collected during 2005-13 were from samples collected by using monitoring-well equipment; the detected concentrations for those seven field blanks were in the range of 0.02 to $0.80 \mu \mathrm{g} / \mathrm{L}$.
Laboratory-blank results reported by the NWQL did not show significant variation (table 4); however, the $99^{\text {th }}$ percentile concentrations calculated by the BQS for laboratory blanks $(0.15$ and $0.17 \mu \mathrm{g} / \mathrm{L})$ were about two times greater than the LT-MDL $(0.08 \mu \mathrm{g} / \mathrm{L})$ in place for vanadium for water years 2010-11 (table 5). These results possibly indicate contamination of vanadium in laboratory blanks during that time, yet, establishing an SRL was not necessary based on field-blank results. Therefore, the SRL for vanadium was updated from $0.10 \mu \mathrm{g} / \mathrm{L}$ to "none" starting October 2009 (table 6), and caution should be used when interpreting vanadium data collected at monitoring-well sites.

0

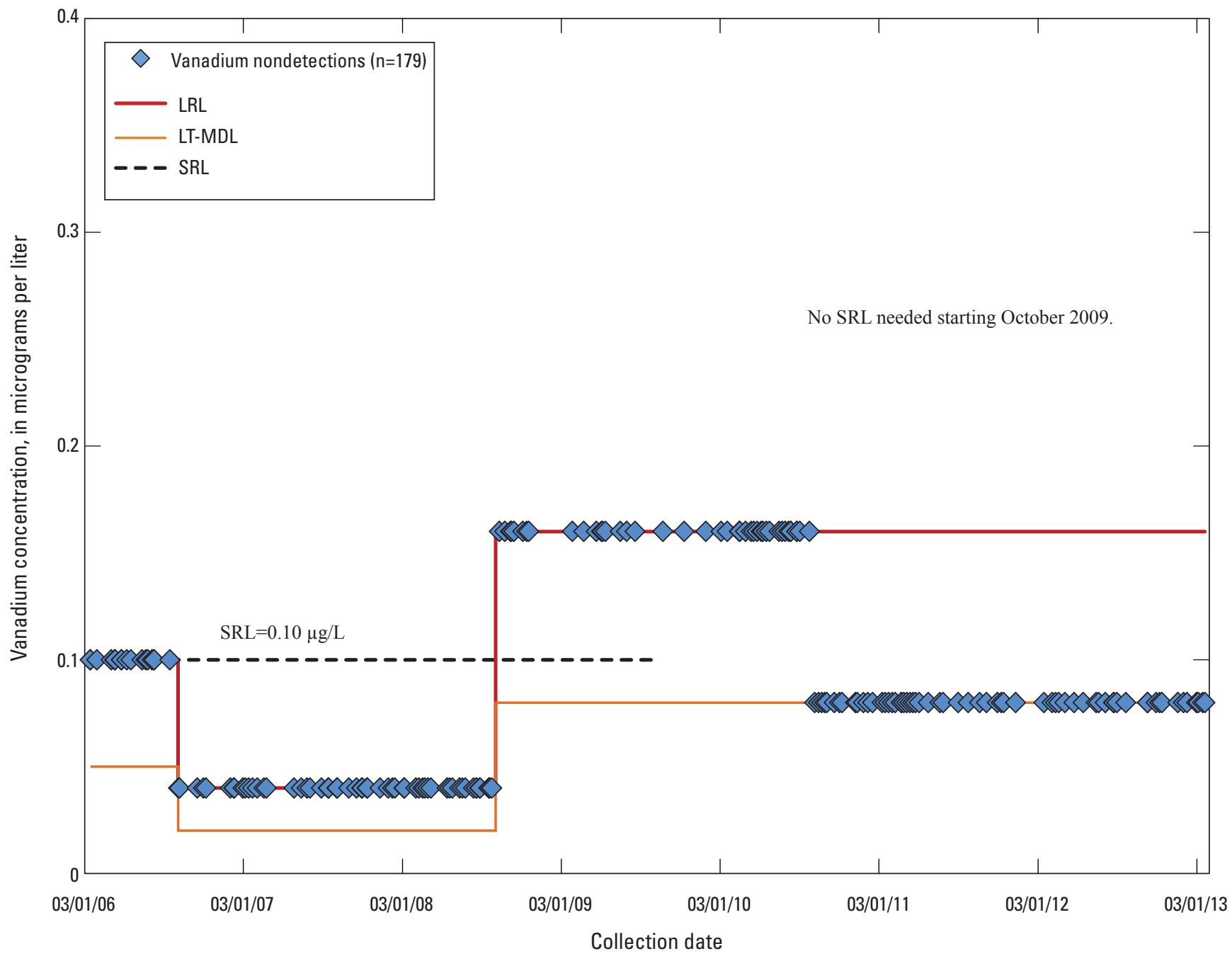

Figure 3. - Continued 


\section{Trace Elements Detected in More Than 5 Percent of Field Blanks (Co, Cu, Fe, Pb, Mn, Mo, Ni, W, Zn)}

Nine trace elements had detection frequencies in field blanks greater than 5 percent during the time period October 2009 through March 2013: cobalt, copper, iron, lead, manganese, molybdenum, nickel, tungsten, and zinc (table 3A). With the exception of nickel, detection frequencies in field blanks for these trace elements increased relative to those for the previous time period (March 2006 through September 2009); the detected concentrations in field blanks also increased for copper, lead, and zinc (figs. 5, 7, and 12).

SRLs for most of these nine trace elements were determined based on the highest of three values: the BD-90/90 concentration for field blanks collected during October 2009 through March 2013, or the highest $99^{\text {th }}$ percentile concentration of laboratory or BQS blind blanks during water years 2010-13 (table 6). Analytical results with concentrations less than the SRLs have an unacceptably high likelihood of significant contamination bias and should be remarked as less than or equal to $(\leq)$ the reported value.

\section{Cobalt (Co)}

From March 2006 through September 2009, none of the 90 field blanks collected for cobalt had a detection (fig. 4; table 3A). From October 2009 through March 2013, 88 of the 89 field blanks ( 99 percent) collected for cobalt had detections. The BD-90/90 concentration calculated for field blanks collected October 2009 through March 2013 was $0.38 \mu \mathrm{g} / \mathrm{L}$ (table 6), with detected concentrations in the range of 0.02 to $0.53 \mu \mathrm{g} / \mathrm{L}$.

Cobalt was not detected in any of the 38 source-solution blanks. Laboratory-blank results reported by the NWQL did not show significant variation (table 4 ). The $99^{\text {th }}$ percentile concentrations for laboratory blanks for water years 2010-12 and for BQS blind blanks for 2012 were greater than the LT-MDLs in place for cobalt (table 5). The $99^{\text {th }}$ percentile concentration for laboratory blanks for 2012 was $0.041 \mu \mathrm{g} / \mathrm{L}$, about two times greater than the LT-MDL $(0.021 \mu \mathrm{g} / \mathrm{L})$. However, the positive bias observed in internal and BQS QC results could not fully explain the contamination of cobalt in field blanks.

The marked increase in detection frequency for cobalt in field blanks was hypothesized to be caused by the capsule filters used to collect samples for trace-element analyses. Beginning in October 2009, high-capacity 0.45-micrometer pore-size capsule filters from Pall Corporation (Port Washington, New York) were in regular use by the GAMAPBP after the NWQL replaced the supply for capsule filters from Whatman (Piscataway, New Jersey) to Pall, due to a performance issue of the Whatman filters in relation to nutrients (USGS Office of Water Quality Information Note 2009.06, written commun., April 2009). Cobalt was not detected in any of the three unfiltered field blanks (see second paragraph of Results section for more information about the unfiltered field blanks). Only one cobalt nondetection in the dataset was used for this evaluation; that field blank was collected in 2010 for GAMA-PBP. Field notes show no indication that the sample was not properly filtered, so it was included in the dataset used for the present study. The hypothesis that the capsule filters were the source of contamination was confirmed by communication with other USGS WSCs where similar field-blank results were observed (Timothy Oden, U.S. Geological Survey, written commun., May 2013). NWQL certificates of analysis for the capsule filters were reviewed for filters supplied during 2009-13. Certificates for five lots of filters (Pall lot numbers FW8545, FW0639, FW0967, FW1422, and FW0242) indicated a recurrent issue with cobalt detections in laboratory-prepared capsule-filter blanks, but at concentrations up to only $0.04 \mu \mathrm{g} / \mathrm{L}$.

Of the 24 trace elements, cobalt was the only constituent that had a higher detection frequency for the field blanks (99 percent) than for the associated groundwater samples (82 percent) during October 2009 through March 2013 (table 3B). Additionally, detected concentrations of cobalt in field blanks were typically greater than the associated groundwater samples; when detected, the median cobalt concentration in the associated groundwater samples was 
$0.055 \mu \mathrm{g} / \mathrm{L}$, whereas the median field-blank concentration was $0.155 \mu \mathrm{g} / \mathrm{L}$ (fig. 4). The lower detection frequency and measured concentrations for the associated groundwater samples suggest that environmental samples may be less susceptible to contamination bias compared to the QC samples. Before a groundwater sample was collected for trace elements, the capsule filter was pre-rinsed with $1 \mathrm{~L}$ of deionized water and then rinsed with $1 \mathrm{~L}$ of native water.

Instead of assigning an SRL for cobalt based on the BD-90/90 concentration for field blanks, all groundwater results for cobalt collected starting when the Pall filters were in use, October 2009, were coded as "reviewed and rejected" (table 6). Cobalt does not currently have a regulatory benchmark for drinking water, and therefore rejecting the data does not interfere with the main project goal for the GAMAPBP. For the GAMA Program, cobalt results for groundwater samples are censored by changing the data-quality-indicator code in NWIS to "Q," and by adding the result-level comment, "Upon careful review, this result has been rejected per Davis and others, 2014." For samples collected at spring sites that were not filtered, any existing contamination bias caused by filtering would not be present; however, the number of unfiltered field blanks was too few to provide statistically reliable information for unfiltered samples.

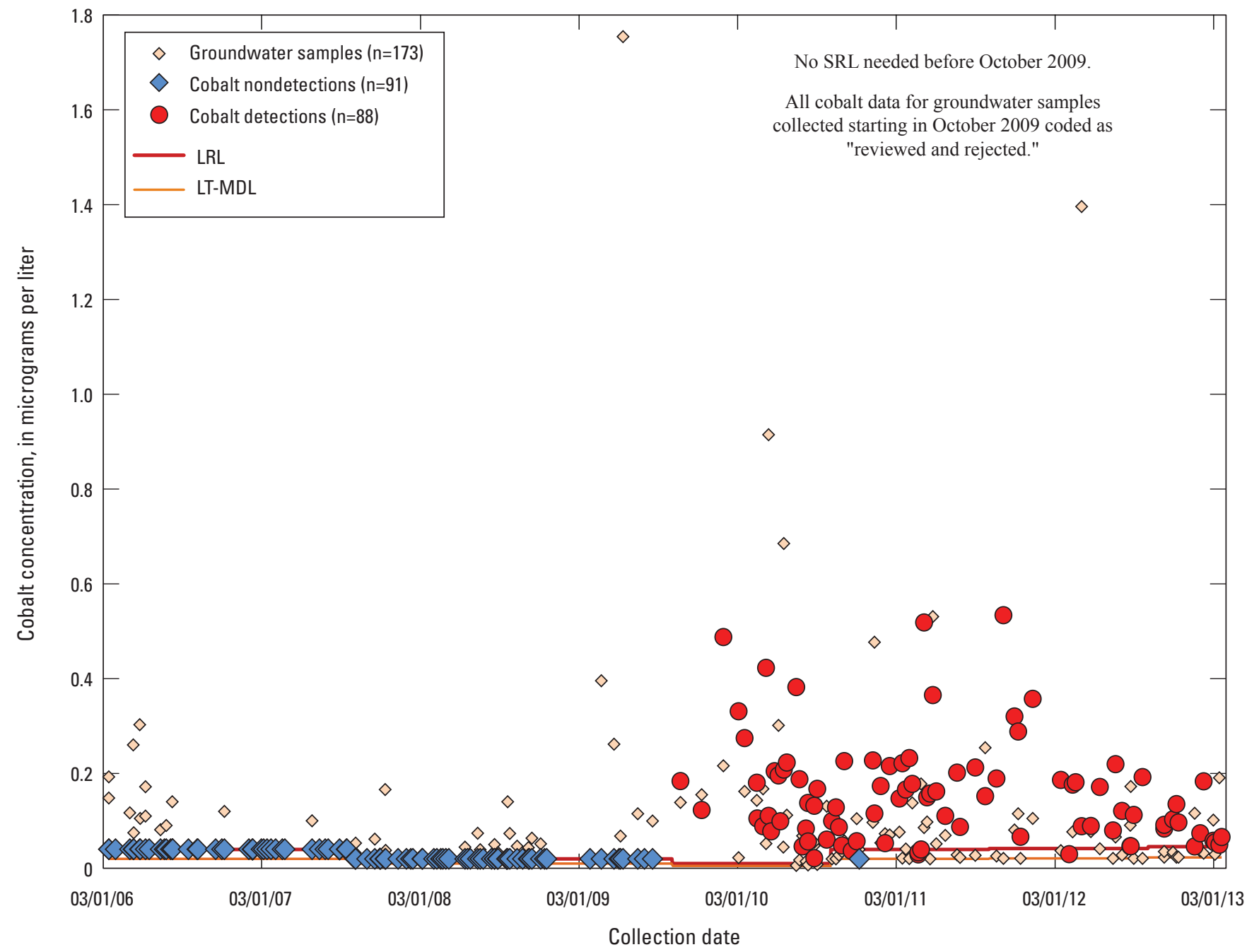

Figure 4. Cobalt concentrations in field blanks and groundwater samples collected March 2006 through March 2013, plotted in timeseries with the laboratory reporting levels (LRLs), and long-term method detection levels (LT-MDLs), Groundwater Ambient Monitoring and Assessment (GAMA) Priority Basin Project. [ $\mu \mathrm{g} / \mathrm{L}$, micrograms per liter] 


\section{Copper (Cu)}

From March 2006 through September 2009, 8 of the 90 field blanks ( 8.9 percent) collected for copper had detections (fig. 5; table 3A). From October 2009 through March 2013, 30 of the 89 field blanks (34 percent) collected for copper had detections, with greatest concentrations occurring mostly in 2011. The BD-90/90 concentration calculated for field blanks collected October 2009 through March 2013 was $2.1 \mu \mathrm{g} / \mathrm{L}$ (table 6); detected concentrations were in the range of 0.51 to $359 \mu \mathrm{g} / \mathrm{L}$. The field blank with a high concentration of copper $(359 \mu \mathrm{g} / \mathrm{L})$ was collected during a NAWQA study in May 2012 with a long line, and the concentration was more than ten times the concentration detected in the subsequently collected groundwater sample $(2.64 \mu \mathrm{g} / \mathrm{L})$. Other detected trace elements in the field blank were cobalt, lead, and manganese at typical field-blank concentrations $(0.09,0.04$, and $0.16 \mu \mathrm{g} / \mathrm{L}$, respectively). Copper was not detected in the source-solution blank collected during the NAWQA study in March 2012 for this IBW lot number or in any other source-solution blank. The anomalous high field-blank concentration represents the possibility for random contamination of copper in any given field blank and was therefore included in the BD-90/90 calculation. Had this sample been omitted from the dataset, the BD-90/90 concentration would have been $2.0 \mu \mathrm{g} / \mathrm{L}$.

Laboratory-blank results reported by the NWQL did not show significant variation (table 4). The $99^{\text {th }}$ percentile concentrations calculated by the BQS for laboratory blanks for water years 2010-11 and for blind blanks for 2011 were greater than the LT-MDL $(0.5 \mu \mathrm{g} / \mathrm{L})$ in place for copper (table 5). Contamination bias is more likely caused by the equipment and processes used to collect samples in the field than by laboratory processes, and this bias has showed no improvement since the last review. Therefore, the SRL for copper increased from 1.7 to $2.1 \mu \mathrm{g} / \mathrm{L}$ starting October 2009, based on the BD-90/90 concentration (table 6). This SRL of $2.1 \mu \mathrm{g} / \mathrm{L}$ is far below the AL-US for copper of $1,300 \mu \mathrm{g} / \mathrm{L}$.

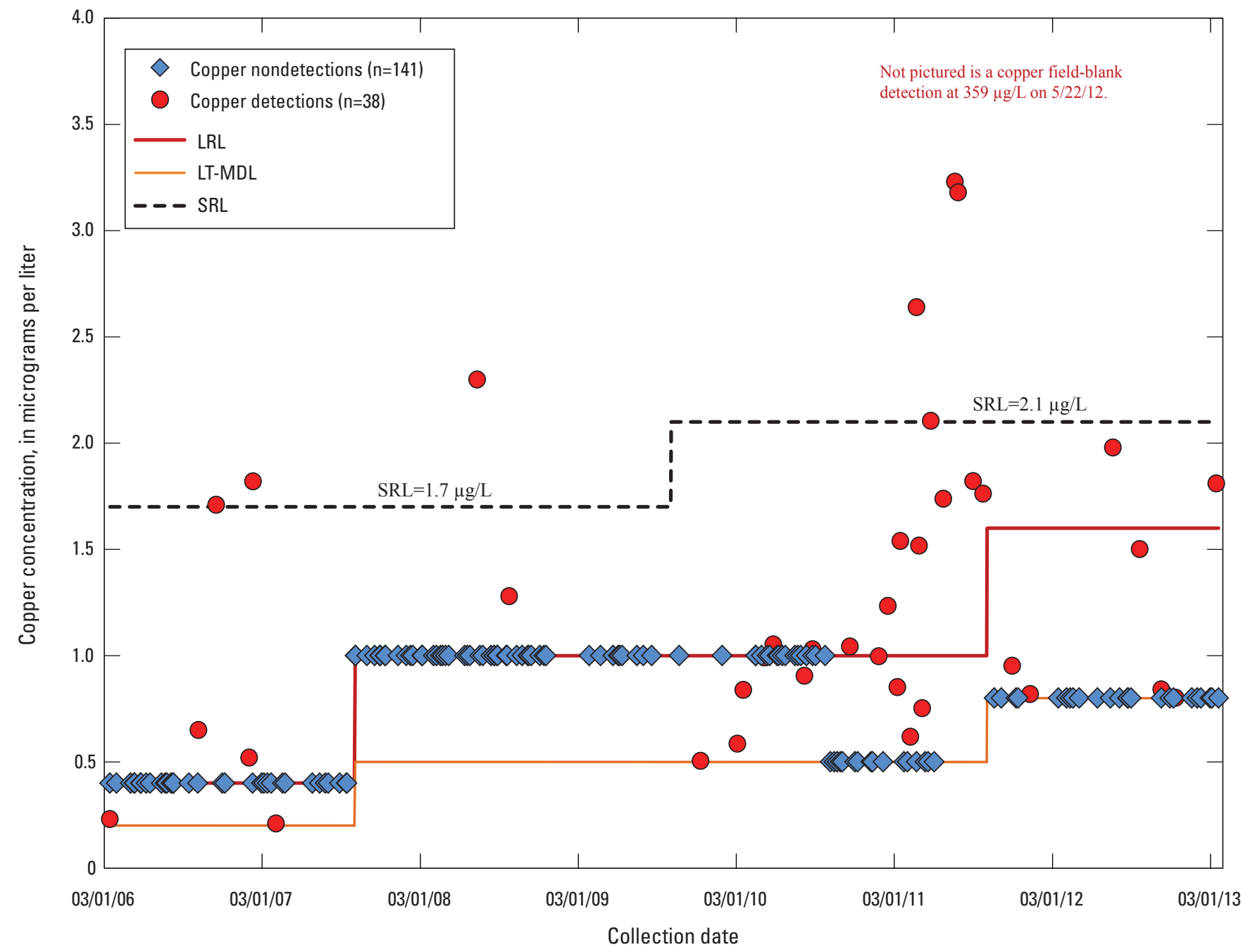

Figure 5. Copper concentrations in field blanks collected March 2006 through March 2013, plotted in time-series with the study reporting levels (SRLs), laboratory reporting levels (LRLs), and long-term method detection levels (LT-MDLs), Groundwater Ambient Monitoring and Assessment (GAMA) Priority Basin Project. [ $\mu \mathrm{g} / \mathrm{L}$, micrograms per liter] 


\section{Iron (Fe)}

From March 2006 through September 2009, 2 of the 87 field blanks ( 2.3 percent) collected for iron had detections (fig. 6; table 3A). From October 2009 through March 2013, 7 of the 86 field blanks ( 8.1 percent) had detections; detected concentrations ranged from 3.4 to $13.3 \mu \mathrm{g} / \mathrm{L}$. The BD-90/90 concentration calculated from field blanks collected during October 2009 through March 2013 was $4.3 \mu \mathrm{g} / \mathrm{L}$ (table 6). Iron was detected at $3.2 \mu \mathrm{g} / \mathrm{L}$ in 1 of the 32 source-solution blanks collected in 2007; iron was not detected in the subsequently collected field blank.

Laboratory-blank results reported by the NWQL did not show significant variation (table 4); however, the BQS reported positive bias for iron in the blind blanks analyzed by the NWQL near mid-2012. There were 5 detections of iron out of 49 blind blanks for water year 2012, at concentrations 3.34, 3.50, 3.53, 3.83, and $405 \mu \mathrm{g} / \mathrm{L}$ (Struzeski, 2013). The $99^{\text {th }}$ percentile concentrations for BQS blind blanks for water years 2010 and 2012 and the calculated LT-MDL for 2012 were greater than the LT-MDLs in place for iron (table 5). The LT-MDLs were raised from 3 to $3.2 \mu \mathrm{g} / \mathrm{L}$ for 2011 and from 3.2 to $4.0 \mu \mathrm{g} / \mathrm{L}$ for 2013 , which mitigated most of the potential bias originating from laboratory processes.

The BD-90/90 concentration calculated for the Olsen and others (2010) SRL was a nondetection; however, a conservative SRL equal to the LRL in place for most of 2004-08 $(6 \mu \mathrm{g} / \mathrm{L})$ had been set based on low-level contamination indicated by BQS blind blanks. Because the field-blank results for iron showed no improvement following the previous review and blind blanks indicate some positive bias, the updated SRL should be equal to or greater than the previously determined SRL. Therefore, the SRL for iron was not updated from the previous SRL of $6 \mu \mathrm{g} / \mathrm{L}$ (table 6). This SRL of $6 \mu \mathrm{g} / \mathrm{L}$ is far below the SMCL-CA for iron of $300 \mu \mathrm{g} / \mathrm{L}$.

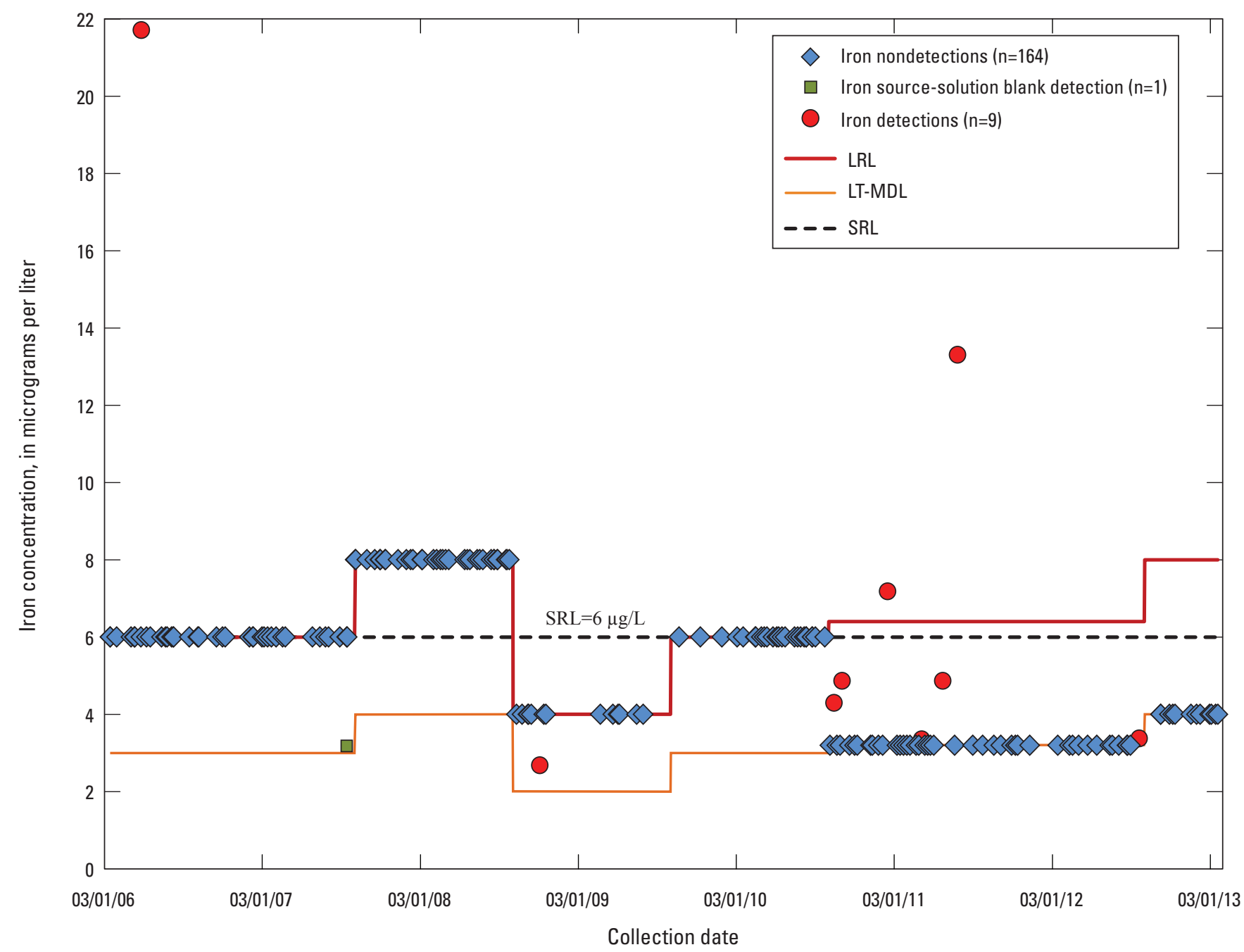

Figure 6. Iron concentrations in field and source-solution blanks collected March 2006 through March 2013, plotted in time-series with the study reporting levels (SRLs), laboratory reporting levels (LRLs), and long-term method detection levels (LT-MDLs), Groundwater Ambient Monitoring and Assessment (GAMA) Priority Basin Project. [ $\mathrm{g} / \mathrm{L}$, micrograms per liter] 


\section{Lead $(\mathrm{Pb})$}

From March 2006 through September 2009, 16 of the 90 field blanks (18 percent) collected for lead had detections (fig. 7; table 3A). From October 2009 through March 2013, 49 of the 89 field blanks (55 percent) collected for lead had detections, with most of the greatest concentrations occurring in 2010-12. The BD-90/90 concentration calculated for field blanks collected October 2009 through March 2013 was $0.82 \mu \mathrm{g} / \mathrm{L}$ (table 6); detected concentrations ranged from 0.02 to $1.7 \mu \mathrm{g} / \mathrm{L}$.

Some, but not all, of the increase in detections can be attributed to the gradual decrease of the LT-MDL from $0.06 \mu \mathrm{g} / \mathrm{L}$ to $0.015 \mu \mathrm{g} / \mathrm{L}$ during water years $2008-10$. Lead was detected in 1 of the 38 source-solution blanks collected. This source-solution blank was collected in November 2008 and had a concentration of $0.11 \mu \mathrm{g} / \mathrm{L}$, equal to the concentration in the subsequently collected field blank. Lead was not detected in a source-solution blank collected in March 2009 with the same lot of IBW. Laboratory and BQS QC data did not indicate significant positive bias or variation for lead (tables 4- ). The main source of contamination observed in the field blanks is likely the sampling equipment. The contamination bias for lead observed by Olsen and others (2010) has shown no sign of improvement and actually appeared to worsen since 2010. Therefore, the SRL for lead increased from $0.65 \mu \mathrm{g} / \mathrm{L}$ to $0.82 \mu \mathrm{g} / \mathrm{L}$ starting October 2009 , based on the BD-90/90 concentration (table 6). This SRL of $0.82 \mu \mathrm{g} / \mathrm{L}$ is far below the AL-US for lead of $15 \mu \mathrm{g} / \mathrm{L}$.

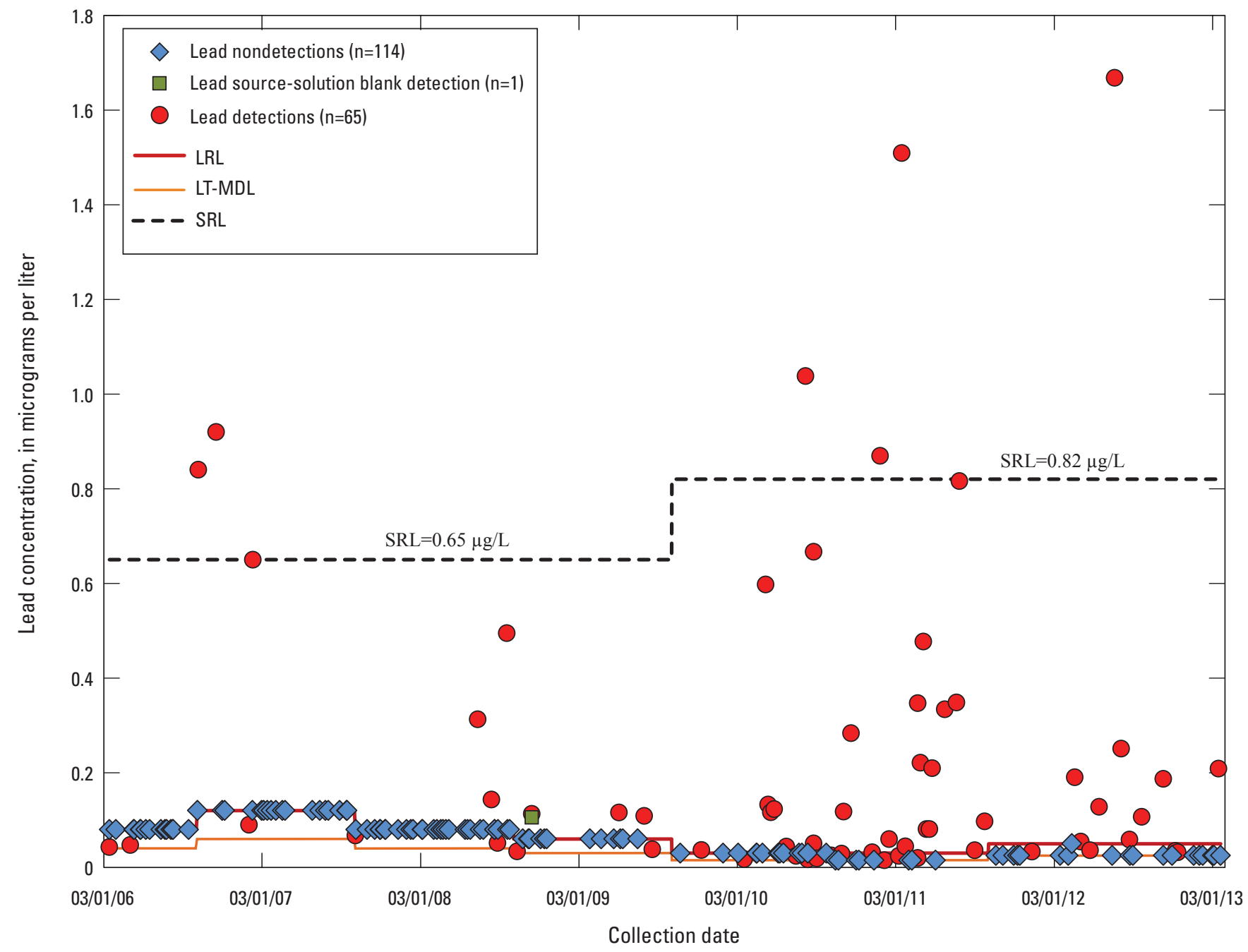

Figure 7. Lead concentrations in field and source-solution blanks collected March 2006 through March 2013, plotted in time-series with the study reporting levels (SRLs), laboratory reporting levels (LRLs), and long-term method detection levels (LT-MDLs), Groundwater Ambient Monitoring and Assessment (GAMA) Priority Basin Project. [ $\mu \mathrm{g} / \mathrm{L}$, micrograms per liter] 


\section{Manganese (Mn)}

From March 2006 through September 2009, none of the 90 field blanks collected for manganese had a detection (fig. 8; table 3A). From October 2009 through March 2013, 68 of the 89 field blanks (76 percent) collected for manganese had detections. The BD-90/90 concentration calculated for field blanks collected October 2009 through March 2013 was $0.66 \mu \mathrm{g} / \mathrm{L}$ (table 6 ), with detected concentrations in the range of 0.14 to $0.91 \mu \mathrm{g} / \mathrm{L}$.

Manganese was not detected in any of the source-solution blanks. Laboratory-blank results reported by the NWQL did not show significant variation (table 4). The $99^{\text {th }}$ percentile concentrations for laboratory blanks for $2011(0.16 \mu \mathrm{g} / \mathrm{L})$ and for BQS blind blanks for $2012(0.15 \mu \mathrm{g} / \mathrm{L})$ were greater than the LT-MDL $(0.13 \mu \mathrm{g} / \mathrm{L})$ in place for manganese (table 5). However, the positive bias observed in internal and BQS QC results could not fully explain the contamination of manganese in field blanks.
Because manganese field-blank results showed a trend parallel to the cobalt results, the source of contamination was likely the same for both trace elements. The other USGS WSCs that observed an increase in cobalt field-blank detections also reported an increase in manganese detections (Timothy Oden, U.S. Geological Survey, written commun., 2013). In addition, the highest concentrations of manganese and cobalt detected in field blanks occurred in the same samples, and none of the three unfiltered field blanks had detected concentrations of manganese (see second paragraph of Results section for more information about the unfiltered field blanks). Unlike cobalt, manganese was not reported in the certificates of analysis for the capsule filters for 2009-13 to have elevated concentrations detected in laboratory filter blanks. The effect that rinsing filters with native water has on reducing contamination bias is not discernible because manganese concentrations in groundwater samples are generally greater than in field-blank samples; when detected, the median manganese concentration in the associated

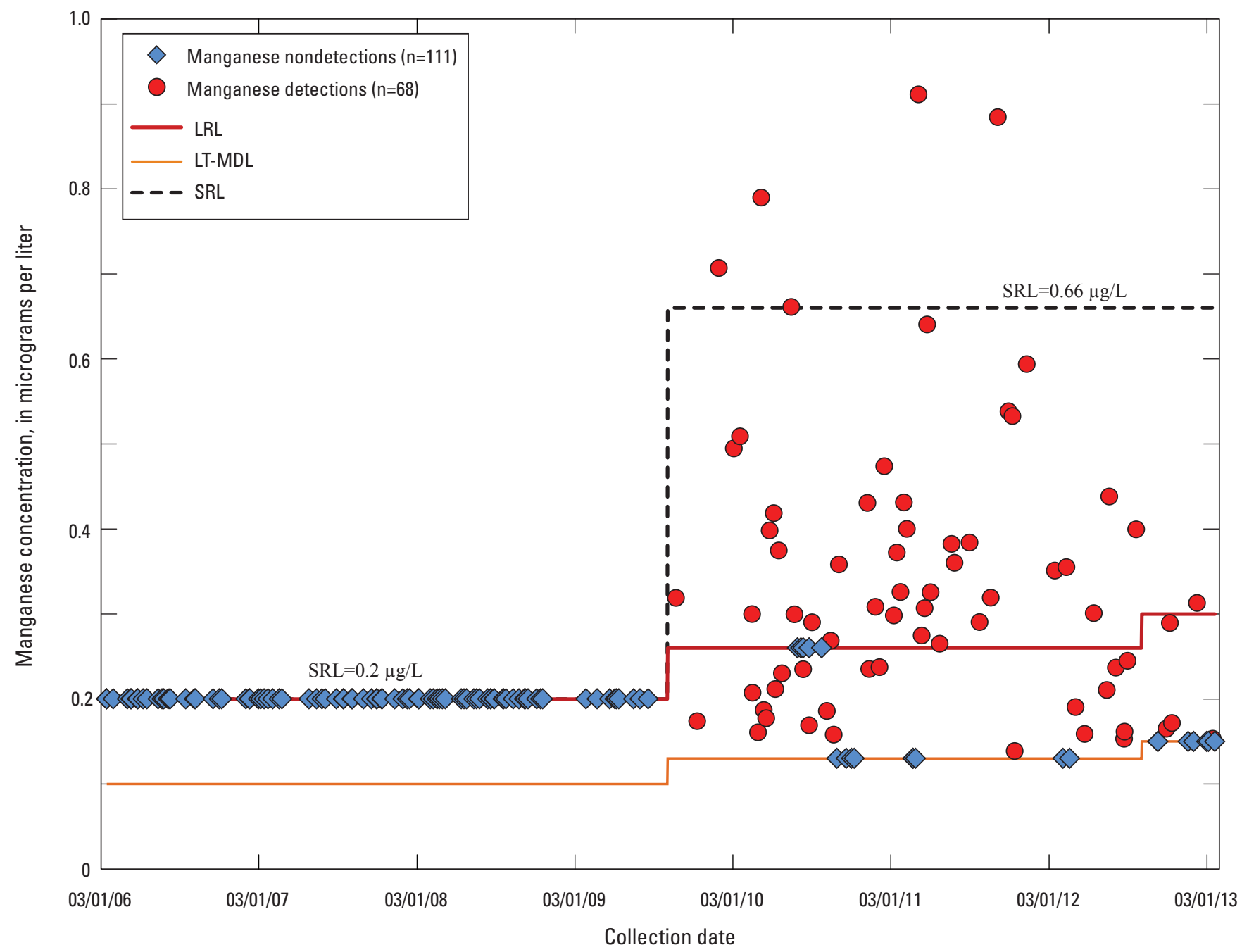

Figure 8. Manganese concentrations in field blanks collected March 2006 through March 2013, plotted in time-series with the study reporting levels (SRLs), laboratory reporting levels (LRLs), and long-term method detection levels (LT-MDLs), Groundwater Ambient Monitoring and Assessment (GAMA) Priority Basin Project. [ $\mu \mathrm{g} / \mathrm{L}$, micrograms per liter] 
groundwater samples was $4.4 \mu \mathrm{g} / \mathrm{L}$, whereas the median fieldblank concentration was $0.31 \mu \mathrm{g} / \mathrm{L}$.

The SRL for manganese increased from 0.2 to $0.66 \mu \mathrm{g} / \mathrm{L}$ starting October 2009, based on the BD-90/90 concentration for field blanks collected October 2009 through March 2013 (table 6). This SRL of $0.66 \mu \mathrm{g} / \mathrm{L}$ is far below the SMCL-CA for manganese of $50 \mu \mathrm{g} / \mathrm{L}$.

\section{Molybdenum (Mo)}

From March 2006 through September 2009, none of the 90 field blanks collected for molybdenum had a detection (fig. 9; table 3A). From October 2009 through March 2013, 7 of the 89 field blanks ( 7.9 percent) had detections. Most of the detected concentrations were less than twice the LT-MDL of $0.014 \mu \mathrm{g} / \mathrm{L}$, except for one concentration at $0.044 \mu \mathrm{g} / \mathrm{L}$. The BD-90/90 concentration calculated for molybdenum from field blanks collected October 2009 through March 2013 was $0.019 \mu \mathrm{g} / \mathrm{L}$. Molybdenum was not detected in any of the
38 source-solution blanks. The LT-MDL decreased by more than an order of magnitude for molybdenum, from 0.2 to $0.014 \mu \mathrm{g} / \mathrm{L}$ during water years $2007-10$, which would explain the increased detection frequency in field blanks.

Laboratory-blank results reported by the NWQL did not show significant variation (table 4). However, the $99^{\text {th }}$ percentile concentrations for laboratory blanks for 2011-12 (0.016 and $0.023 \mu \mathrm{g} / \mathrm{L}$, respectively) and for BQS blind blanks for $2013(0.019 \mu \mathrm{g} / \mathrm{L})$ were greater than the LT-MDL $(0.014 \mu \mathrm{g} / \mathrm{L})$ in place for molybdenum (table 5). The $99^{\text {th }}$ percentile concentrations for internal and blind blanks were comparable to the BD-90/90 concentration $(0.019 \mu \mathrm{g} / \mathrm{L})$, suggesting that the laboratory equipment and methods could be significantly contributing to the positive bias observed in the field-blank results. Therefore, the SRL for molybdenum was updated from "none" to $0.023 \mu \mathrm{g} / \mathrm{L}$ starting October 2009 , based on the highest $99^{\text {th }}$ percentile concentration for laboratory blanks (table 6). This SRL of $0.023 \mu \mathrm{g} / \mathrm{L}$ is far below the HAL-US for molybdenum of $40 \mu \mathrm{g} / \mathrm{L}$.

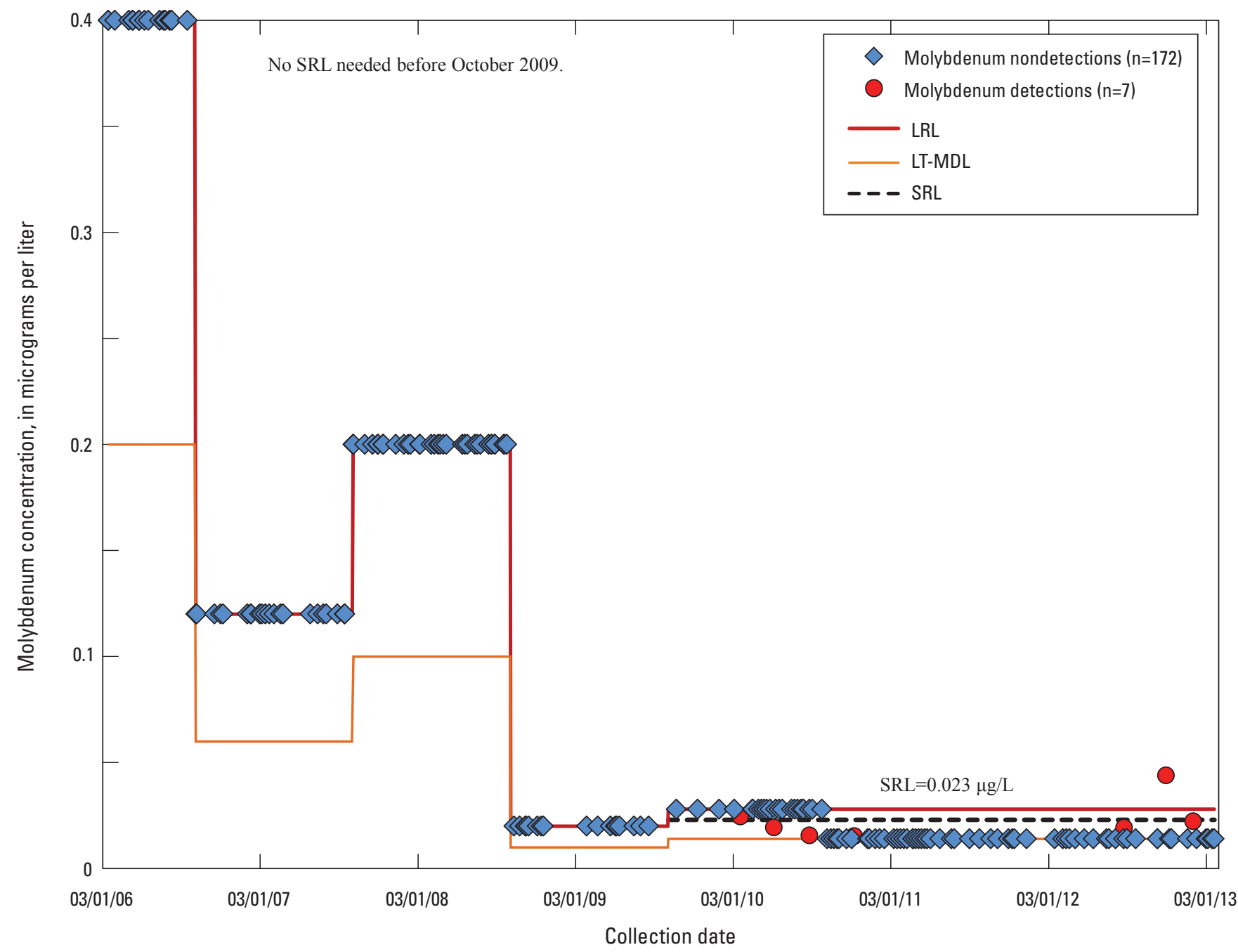

Figure 9. Molybdenum concentrations in field blanks collected March 2006 through March 2013, plotted in time-series with the study reporting levels (SRLs), laboratory reporting levels (LRLs), and long-term method detection levels (LT-MDLs), Groundwater Ambient Monitoring and Assessment (GAMA) Priority Basin Project. [ $\mu \mathrm{g} / \mathrm{L}$, micrograms per liter] 


\section{Nickel (Ni)}

From March 2006 through September 2009, 8 of the 90 field blanks ( 8.9 percent) collected for nickel had detections (fig. 10; table 3A). From October 2009 through March 2013, 5 of the 89 field blanks (5.6 percent) collected for nickel had detections. The BD-90/90 concentration calculated for field blanks collected October 2009 through March 2013 was $0.06 \mu \mathrm{g} / \mathrm{L}$ (table 6 ); detected concentrations were in the range of 0.06 to $1.02 \mu \mathrm{g} / \mathrm{L}$ and had no temporal pattern, similar to the results observed by Olsen and others (2010).

The LT-MDL gradually increased from $0.03 \mu \mathrm{g} / \mathrm{L}$ in 2006 to $0.06 \mu \mathrm{g} / \mathrm{L}$ in October 2009, which would explain some of the decrease in detection frequency; half of the nickel detections for March 2006 through September 2009 were at concentrations less than $0.06 \mu \mathrm{g} / \mathrm{L}$. Nickel was detected in one source-solution blank at $0.09 \mu \mathrm{g} / \mathrm{L}$, but was not detected in the subsequently collected field blank or the source-solution blank collected in March 2009 with the same lot of IBW.
Laboratory-blank results reported by the NWQL did not show significant variation (table 4). However, BQS QC data for blind blanks showed slight positive bias in water year 2010, with a $99^{\text {th }}$ percentile concentration for BQS blind blanks at $0.21 \mu \mathrm{g} / \mathrm{L}$ and a calculated LT-MDL of $0.09 \mu \mathrm{g} / \mathrm{L}$ (table 5).

Olsen and others (2010) set the SRL for nickel equal to the BD-90/90 concentration, $0.36 \mu \mathrm{g} / \mathrm{L}$, on the basis of possible low-level contamination from the sampling equipment. Field-blank results have not shown much improvement since the last review; however, the BD-90/90 concentration for field blanks collected October 2009 through March $2013(0.06 \mu \mathrm{g} / \mathrm{L})$ was less than the highest LT-MDL concentration for nickel $(0.09 \mu \mathrm{g} / \mathrm{L})$, necessitating an alternate source for the SRL concentration (table 6). Therefore, the SRL for nickel decreased from 0.36 to $0.21 \mu \mathrm{g} / \mathrm{L}$ starting October 2009, based on the highest $99^{\text {th }}$ percentile concentration for laboratory blanks (table 6). This SRL of $0.21 \mu \mathrm{g} / \mathrm{L}$ is far below the MCL-CA for nickel of $100 \mu \mathrm{g} / \mathrm{L}$.

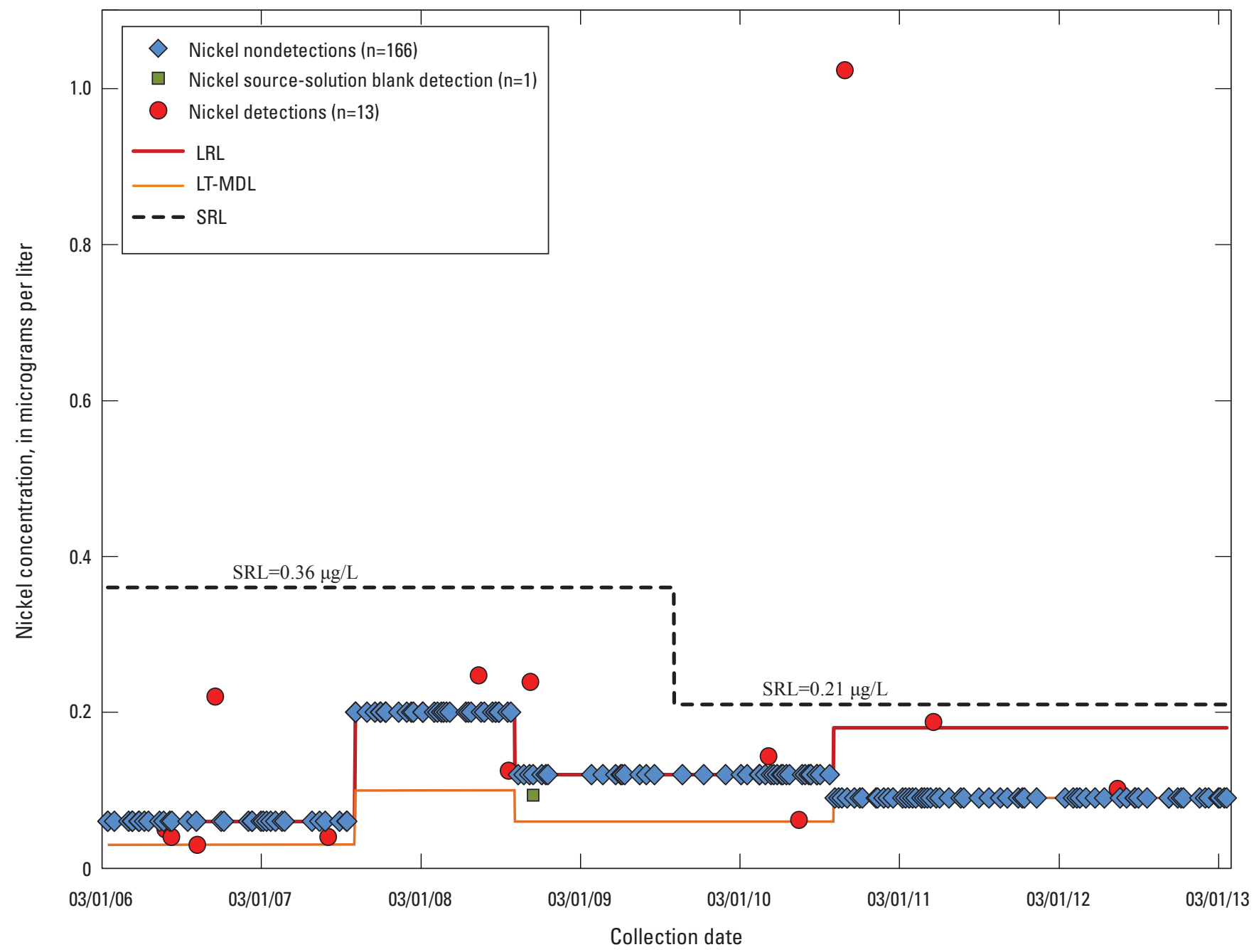

Figure 10. Nickel concentrations in field and source-solution blanks collected March 2006 through March 2013, plotted in time-series with the study reporting levels (SRLs), laboratory reporting levels (LRLs), and long-term method detection levels (LT-MDLs), Groundwater Ambient Monitoring and Assessment (GAMA) Priority Basin Project. [ $\mathrm{gg} / \mathrm{L}$, micrograms per liter] 


\section{Tungsten (W)}

From March 2006 through September 2009, 1 of the 76 field blanks (1.3 percent) collected for tungsten had a detection (fig. 11; table 3A); the detected concentration was $0.22 \mu \mathrm{g} / \mathrm{L}$. From October 2009 through March 2013, 3 of the 56 field blanks (5.4 percent) collected for tungsten had detections. The detected concentrations were greater than twice the LT-MDL $(0.01 \mu \mathrm{g} / \mathrm{L})$ and in the narrow range of 0.023 to $0.030 \mu \mathrm{g} / \mathrm{L}$. The BD-90/90 concentration calculated from field blanks collected October 2009 through March 2013 was equal to the third highest concentration: $0.023 \mu \mathrm{g} / \mathrm{L}$ (table 6). The LT-MDL decreased from 0.03 to $0.01 \mu \mathrm{g} / \mathrm{L}$ in October 2008, which would explain some of the increase in detection frequency. Tungsten was not detected in any of the 32 source-solution blanks for which it was analyzed, and the internal and BQS QC data did not indicate any systematic laboratory contamination for tungsten (tables 4- ).
Olsen and others (2010) set the SRL to $0.11 \mu \mathrm{g} / \mathrm{L}$ for tungsten on the basis of field blanks and low-level contamination observed in BQS blind blanks. Since the last review, results for laboratory and blind blanks do not indicate any systematic contamination bias. There was an increase in detection frequency in field blanks for tungsten not previously observed. This result is likely due to the fact that detections were not previously reportable at such low concentrations as was observed in field blanks since lowering the LT-MDL in 2008. Therefore, the SRL for tungsten decreased from 0.11 to $0.023 \mu \mathrm{g} / \mathrm{L}$ starting October 2009 , based on the BD-90/90 concentration for October 2009 through March 2013 (table 6).

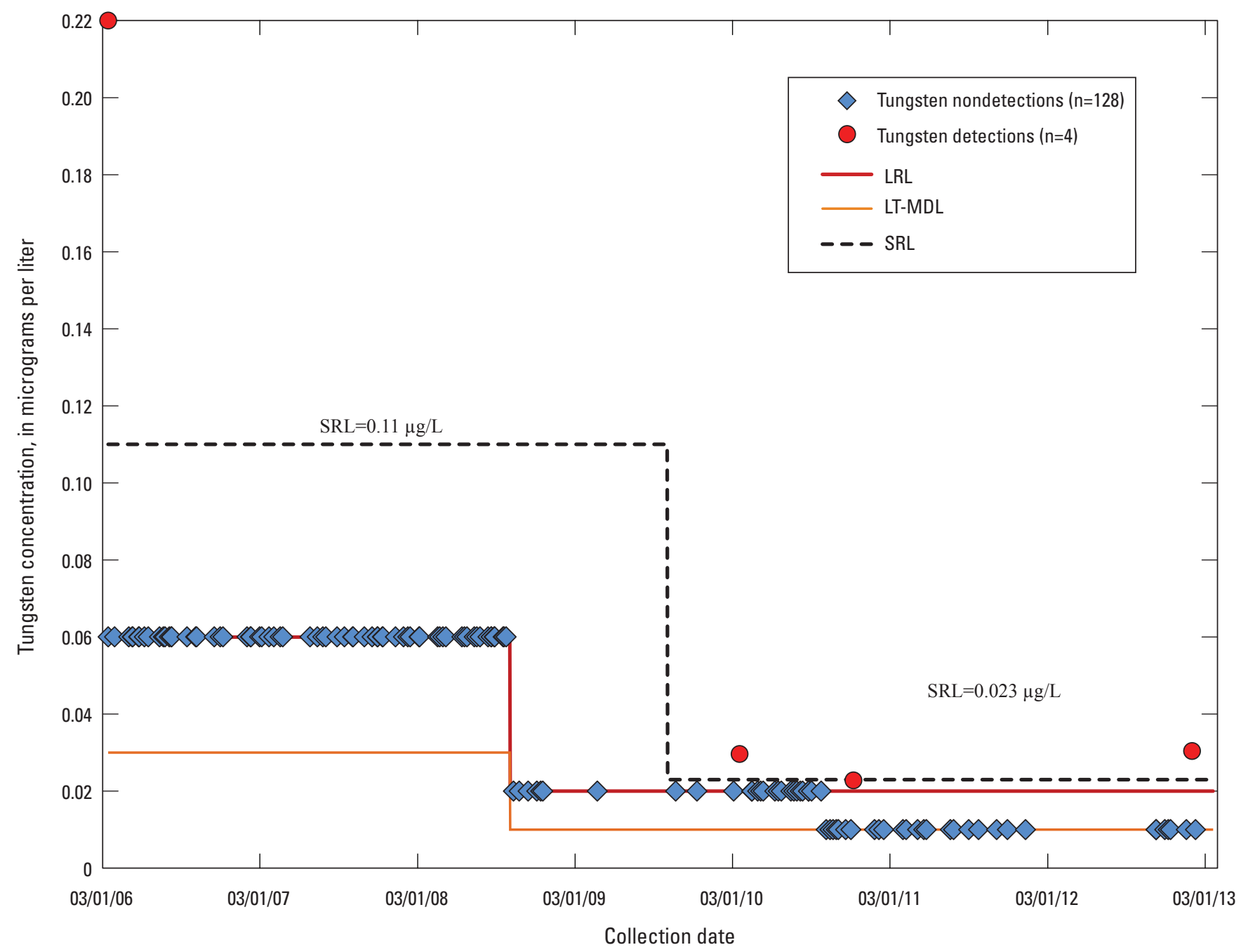

Figure 11. Tungsten concentrations in field blanks collected March 2006 through March 2013, plotted in time-series with the study reporting levels (SRLs), laboratory reporting levels (LRLs), and long-term method detection levels (LT-MDLs), Groundwater Ambient Monitoring and Assessment (GAMA) Priority Basin Project. [ $\mu \mathrm{g} / \mathrm{L}$, micrograms per liter] 


\section{Zinc (Zn)}

From March 2006 through September 2009, 12 of the 90 field blanks (13 percent) collected for zinc had detections (fig. 12; table 3A); the detected concentrations were in the range of 0.3 to $11.5 \mu \mathrm{g} / \mathrm{L}$. From October 2009 through March 2013, 29 of the 89 field blanks (33 percent) collected for zinc had detections, with greatest concentrations occurring in 2011. The BD-90/90 concentration calculated for field blanks collected October 2009 through March 2013 was $6.2 \mu \mathrm{g} / \mathrm{L}$ (table 6); detected concentrations were in the range of 1.4 to $8.6 \mu \mathrm{g} / \mathrm{L}$. Zinc was not detected in any of the sourcesolution blanks, and laboratory and BQS blind blanks did not indicate any significant or recurring contamination bias (tables 4- ).
The contamination bias for zinc in field blanks as observed by Olsen and others (2010) has shown no sign of improvement since the last review and appeared to increase in 2011. Therefore, the SRL for zinc increased from $4.8 \mu \mathrm{g} / \mathrm{L}$ to $6.2 \mu \mathrm{g} / \mathrm{L}$ starting October 2009, based on the BD-90/90 concentration (table 6). This SRL of $6.2 \mu \mathrm{g} / \mathrm{L}$ is far below the SMCL-CA for zinc of $5,000 \mu \mathrm{g} / \mathrm{L}$.

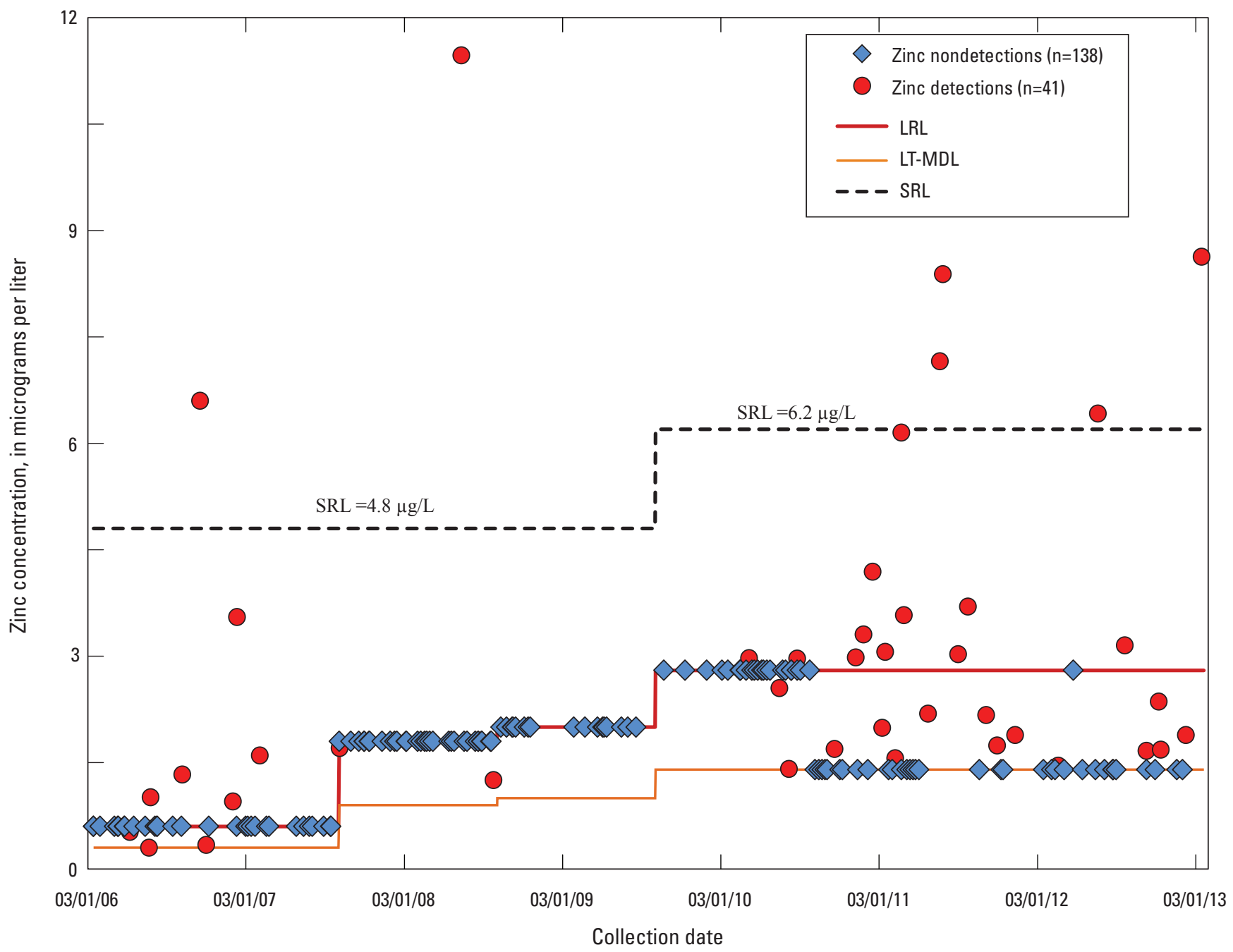

Figure 12. Zinc concentrations in field blanks collected March 2006 through March 2013, plotted in time-series with the study reporting levels (SRLs), laboratory reporting levels (LRLs), and long-term method detection levels (LT-MDLs), Groundwater Ambient Monitoring and Assessment (GAMA) Priority Basin Project. [ $\mu \mathrm{g} / \mathrm{L}$, micrograms per liter] 


\section{Summary}

Groundwater quality has been analyzed since 2004 as part of the Groundwater Ambient Monitoring and Assessment (GAMA) Program Priority Basin Project (PBP). The program is a comprehensive assessment of statewide groundwater quality designed to identify and characterize risks to groundwater resources and to increase the availability of information about groundwater quality to the public. Trace-element field blanks were collected as part of the quality-control process for this program and were reviewed to determine potential bias to environmental sample results. Bias in the environmental data could be attributed to contamination in the field from contact between groundwater and sampling equipment or other contaminant sources, to contamination during processing or shipping, or to method bias during the analysis of samples. Bias can affect the interpretation of results, particularly if any constituents are present in the samples solely as a result of extrinsic contamination that would otherwise be absent from the groundwater sampled. Olsen and others (2010) had previously determined study reporting levels (SRLs) for trace-element results based primarily on field-blank samples collected May 2004 through January 2008.

In this report, data from blanks were evaluated by using the same approach developed by Olsen and others (2010) for assessing potential contamination bias. Twenty-four trace elements were analyzed for in 179 field and equipment blanks collected from March 2006 to March 2013 for the GAMA Program and the National Water-Quality Assessment Program: aluminum ( $\mathrm{Al}$ ), antimony $(\mathrm{Sb})$, arsenic ( $\mathrm{As})$, barium $(\mathrm{Ba})$, beryllium $(\mathrm{Be})$, boron $(\mathrm{B})$, cadmium $(\mathrm{Cd})$, chromium $(\mathrm{Cr})$, cobalt $(\mathrm{Co})$, copper $(\mathrm{Cu})$, iron $(\mathrm{Fe})$, lead $(\mathrm{Pb})$, lithium $(\mathrm{Li})$, manganese (Mn), molybdenum (Mo), nickel (Ni), selenium $(\mathrm{Se})$, silver (Ag), strontium ( $\mathrm{Sr})$, thallium $(\mathrm{Tl})$, tungsten $(\mathrm{W})$, uranium $(\mathrm{U})$, vanadium $(\mathrm{V})$, and zinc $(\mathrm{Zn})$. A review of the field blanks and equipment blanks collected March 2006 through March 2013 by the GAMA-PBP showed that for trace elements that had a change in detection frequency and concentration since the previous review, the shift occurred near October 2009. Results from the field blanks were used to calculate detection frequencies and to estimate the upper limit of contamination bias (BD-90/90) for samples collected October 2009 through March 2013. The BD-90/90 is the $90^{\text {th }}$ percentile concentration of potential extrinsic contamination for greater than 90 percent confidence derived by using the binomial probability distribution from the method reported by Hahn and Meeker (1991). The $99^{\text {th }}$ percentile concentrations for internal laboratory blanks and blind blanks analyzed for water years 2010 through 2013 for each trace element were summarized as reported by the National Water Quality Laboratory (NWQL) and Branch of Quality Systems (BQS). These results were compared to each constituent's reporting level to determine whether an SRL was necessary to minimize the potential for detections in the groundwater samples, attributed principally to contamination bias.

Ten trace elements analyzed ( $\mathrm{Sb}, \mathrm{As}, \mathrm{Be}, \mathrm{B}, \mathrm{Cd}, \mathrm{Li}$, $\mathrm{Se}, \mathrm{Ag}, \mathrm{Tl}$, and $\mathrm{U}$ ) had blank results that did not necessitate establishing SRLs during this review or the review by Olsen and others (2010). Five trace elements (Al, Ba, Cr, Sr, and V) had blank results that necessitated establishing an SRL during the previous review but were determined to no longer need an SRL. One trace element $(\mathrm{Fe})$ had field and laboratoryblank results that necessitated keeping the previous SRL $(6 \mu \mathrm{g} / \mathrm{L})$. Two trace elements (Ni and $\mathrm{W}$ ) had quality-control results that necessitated decreasing the previous SRL, and five trace elements $(\mathrm{Cu}, \mathrm{Pb}, \mathrm{Mn}, \mathrm{Mo}$, and $\mathrm{Zn})$ had field, laboratory, or blind blank results that necessitated establishing an SRL for the first time or increasing the previous SRL. SRLs for $\mathrm{Cu}(2.1 \mu \mathrm{g} / \mathrm{L}), \mathrm{Pb}(0.82 \mu \mathrm{g} / \mathrm{L}), \mathrm{Mn}(0.66 \mu \mathrm{g} / \mathrm{L})$, Mo $(0.023 \mu \mathrm{g} / \mathrm{L}), \mathrm{Ni}(0.21 \mu \mathrm{g} / \mathrm{L}), \mathrm{W}(0.023 \mu \mathrm{g} / \mathrm{L})$, and $\mathrm{Zn}$ $(6.2 \mu \mathrm{g} / \mathrm{L})$ were changed to these levels starting October 2009, based on the BD-90/90 concentration for field blanks or the $99^{\text {th }}$ percentile concentration for laboratory or blind blanks. The SRL for Fe was maintained at $6 \mu \mathrm{g} / \mathrm{L}$, based on the minimum laboratory reporting level for iron. Additionally, starting October 2009, all groundwater results for cobalt were coded as "reviewed and rejected." At all times, SRLs for the constituents were at least an order of magnitude below the regulatory benchmarks established for drinking water for health and aesthetic purposes (cobalt does not currently have a benchmark); therefore, the practice of reporting concentrations below the SRLs as less than or equal to $(\leq)$ the measured value would not prevent the identification of values greater than the drinking-water benchmarks. The primary sources of contamination inferred from this review are biases from the processes used in the field to collect the samples or from laboratory processes or equipment. In particular, contamination in field blanks of cobalt and manganese was attributed to the high-capacity 0.45 -micrometer pore-size capsule filters from Pall Corporation (Port Washington, New York) that were regularly in use by the GAMA-PBP beginning in October 2009 for filtering samples for analysis of trace elements.

The SRLs determined in this report are intended to be used for GAMA groundwater-quality data for samples collected from October 2009 through March 2013, or for as long as quality-control data show contamination similar to what was observed in this report. Quality-control data should be continuously reviewed on at least a study-unit basis in the context of the findings in this report to re-assess the SRLs.

\section{Acknowledgments}

The authors thank the following cooperators for their support: the California State Water Resources Control Board, the California Department of Public Health, the California Department of Water Resources, and Lawrence Livermore National Laboratory. We especially thank the cooperating well owners and water purveyors for their generosity in allowing the USGS to collect groundwater samples from their wells. Funding for this work was provided by Proposition 50 and administered by the State Water Board. 


\section{References}

Belitz, Kenneth, Dubrovsky, N.M., Burow, K.R., Jurgens, Bryant, and Johnson, Tyler, 2003, Framework for a ground-water quality monitoring and assessment program for California: U.S. Geological Survey Water-Resources Investigations Report 03-4166, 78 p. (Also available at http://pubs.usgs.gov/wri/wri034166/.)

Bennett, P.A., Bennett, G.L., V, and Belitz, Kenneth, 2009, Groundwater quality data for the northern Sacramento Valley, 2007-Results from the California GAMA Program: U.S. Geological Survey Data Series 452, 90 p. (Also available at http://pubs.usgs.gov/ds/452.)

California Department of Public Health, 2013a, Chemicals and contaminants in drinking water, accessed August 22, 2013, at http://www.cdph.ca.gov/certlic/drinkingwater/Pages/ Chemicalcontaminants.aspx.

California Department of Public Health, 2013b, EDT library and water quality analyses data and download page, accessed September 19, 2013, at http://www.cdph.ca.gov/ certlic/drinkingwater/Pages/EDTlibrary.aspx.

California State Water Resources Control Board, 2003, Report to the Governor and Legislature-A comprehensive groundwater quality monitoring program for California: Assembly Bill 599, 121 p., accessed January 18, 2013, at http://www.waterboards.ca.gov/gama/docs/final_ab_599 rpt to legis 731 03.pdf.

California State Water Resources Control Board, 2010, Report to the Legislature-Public accessibility to information about groundwater conditions, 49 p., accessed January 18, 2013, at http://www.waterboards.ca.gov/gama/docs/leg_rpt/ groundwater2010.pdf.

Childress, C.J.O., Foreman, W.T., Connor, B.F., and Maloney, T.J., 1999, New reporting procedures based on long-term method detection levels and some considerations for interpretations of water-quality data provided by the U.S. Geological Survey National Water Quality Laboratory: U.S. Geological Survey Open-File Report 99-193, 19 p.

Connor, B.F., 2012, Long term-method detection levels (LT-MDL) for the US Geological Survey, National Water Quality Laboratory: U.S. Geological Survey Branch of Quality Systems LT-MDL Project, accessed January 18, 2013, at http://bqs.usgs.gov/ltmdl.

Densmore, J.N., Fram, M.S., and Belitz, Kenneth, 2009, Ground-water quality data in the Owens and Indian Wells Valleys study unit, 2006-Results from the California GAMA Program: U.S. Geological Survey Data Series 427, 86 p. (Also available at http://pubs.usgs.gov/ds/427.)
Fishman, M.J., 1993, ed., Methods of analysis by the U.S. Geological Survey National Water Quality Laboratory-Determination of inorganic and organic constituents in water and fluvial sediments: U.S. Geological Survey Open-File Report 93-125, 217 p.

Garbarino, J.R., 1999, Methods of analysis by the U.S. Geological Survey National Water Quality Laboratory_-Determination of dissolved arsenic, boron, lithium, selenium, strontium, thallium, and vanadium using inductively coupled plasma-mass spectrometry: U.S. Geological Survey Open-File Report 99-093, 31 p.

Garbarino, J.R., Kanagy, L.K., and Cree, M.E., 2006, Determination of elements in natural-water, biota, sediment, and soil samples using collision/reaction cell inductively coupled plasma-mass spectrometry: U.S. Geological Survey Techniques and Methods, book 5, chap. B1, 88 p.

Hahn, G.J., and Meeker, W.Q., 1991, Statistical intervals-A guide to practitioners: New York, John Wiley and Sons, $392 \mathrm{p}$.

Helsel, D.R., 2005, Insider censoring-Distortion of data with nondetections: Human and Ecological Risk Assessment, v. 11, p. $1127-1137$.

Helsel, D.R., 2006, Fabricating data-How substituting values for nondetects can ruin results, and what can be done about it: Chemosphere, v. 65, no. 11, p. 2434-2439.

Koterba, M.T., Wilde, F.D., and Lapham, W.W., 1995, Groundwater data-collection protocols and procedures for the National Water-Quality Assessment ProgramCollection and documentation of water-quality samples and related data: U.S. Geological Survey Open-File Report 95-399, 113 p.

Lane, S.L., Flanagan, Sarah, and Wilde, F.D., 2003, Selection of equipment for water sampling (ver. 2.0): U.S. Geological Survey Techniques of Water-Resources Investigations, book 9, chap. A2, accessed January 18, 2013, at http://water. usgs.gov/owq/FieldManual/Chapter2/Ch2 contents.html.

Lapham, W.W., Hamilton, P.A., and Myers, D.N., 2005, National Water-Quality Assessment Program-Cycle IIRegional assessments of aquifers: U.S. Geological Survey Fact Sheet 2005-3013, 4 p., accessed February 22, 2014, at http://pubs.usgs.gov/fs/2005/3013/pdf/PASforWeb.pdf.

Olsen, L.D., Fram, M.S., and Belitz, Kenneth, 2010, Review of trace-element field blank data collected for the California Groundwater Ambient Monitoring and Assessment (GAMA) Program, May 2004-January 2008: U.S. Geological Survey Scientific Investigations Report 2009-5220, 47 p. (Also available at http://pubs.usgs.gov/ sir/2009/5220/.) 
State of California, 2001a, Assembly Bill No. 599, Chapter 522, accessed January 18, 2013, at http://www. swrcb.ca.gov/gama/docs/ab_599 bill 20011005 chaptered. pdf.

State of California, 2001b, Groundwater Monitoring Act of 2001: California Water Code, part 2.76, sections 1078010782.3, accessed January 18, 2013, at http://www.leginfo. ca.gov/cgi-bin/displaycode? section=wat\&group $=10001-$ $11000 \&$ file $=10780-10782.3$.

Stevenson, D.L., ed., 2013, Quality management system, U.S. Geological Survey National Water Quality Laboratory: unpublished U.S. Geological Survey Report, version 2.1, 28 May 2013, 74 p., accessed January 6, 2014, at http://nwql.usgs.gov/qms v2.shtml.

Struzeski, T.M., 2012, USGS Inorganic Blind Sample Project (IBSP) - Monitoring and evaluating the National Water Quality Laboratory's inorganic analytical data quality, accessed January 13, 2013, at http://bqs.usgs.gov/ibsp/.

Struzeski, T.M., 2013, Blind blank charts (WY09-WY13): U.S. Geological Survey Branch of Quality Systems Blind Blank Project (BBP), accessed January 13, 2013, at http://bqs.usgs.gov/bbp/.

Struzeski, T.M., variously dated, USGS Inorganic Blind Sample Project (IBSP) - Data quality assessment summaries, accessed January 13, 2013, at http://bqs.usgs.gov/ibsp/qadata.shtml\#.

U.S. Environmental Protection Agency, 1997, Guidelines for establishing test procedures for the analysis of pollutants (App. B, Part 136, Definitions and procedures for the determination of the method detection limit): U.S. Code of Federal Regulations, Title 40, revised January 1, 1997, p. 265-267.

U.S. Environmental Protection Agency, 2013, Drinking water contaminants, accessed August 22, 2013, at http://water.epa.gov/drink/contaminants/.
U.S. Geological Survey, 2010, Changes to the reporting convention and to data qualification approaches for selected analyte results reported by the National Water Quality Laboratory (NWQL): Office of Water Quality Technical Memorandum 2010.07, accessed January 18, 2013, at http://water.usgs.gov/admin/memo/QW/qw10.07.html.

U.S. Geological Survey, 2013, California Groundwater Ambient Monitoring and Assessment (GAMA) Program Priority Basin Project—Shallow Aquifer Assessment: U.S. Geological Survey Fact Sheet 2012-3136, 2 p. (Also available at http://pubs.usgs.gov/fs/2012/3136.)

U.S. Geological Survey, variously dated, National field manual for the collection of water-quality data: U.S. Geological Survey Techniques of Water-Resources Investigations, book 9, chap. A1-A9. (Also available at http://water.usgs.gov/owq/FieldManual/.)

Wilde, F.D., ed., 2004, Cleaning of equipment for water sampling (ver. 2.0): U.S. Geological Survey Techniques of Water-Resources Investigations, book 9, chap. A3, accessed January 18, 2013, at http://pubs.water.usgs.gov/twri9A3/.

Wilde, F.D., ed., 2006, Collection of water samples: U.S. Geological Survey Techniques of Water-Resources Investigations, book 9, chap. A4, accessed January 18, 2013, at http://pubs.water.usgs.gov/twri9A4/.

Wilde, F.D., ed., 2009, Processing of water samples (ver. 2.2): U.S. Geological Survey Techniques of Water-Resources Investigations, book 9, chap. A5, accessed January 18, 2013, at http://water.usgs.gov/owq/FieldManual/chapter5/ html/Ch5 contents.html. 


\section{Glossary}

action level (AL) A legally-enforceable standard set by the USEPA (AL-US) that applies to public-water systems and is designed to protect public health by limiting the levels of contaminants in drinking water. Concentrations of contaminants above this standard trigger requirements for mandatory water treatment.

binomial distribution function This function can be used to determine the conditions under which a specified probability and confidence of success or failure are met. It is sometimes called the "binomial cumulative distribution" or "binomial probability distribution." This nonparametric approach uses the number of samples, rather than actual data, to provide the rank of the data value at which the desired conditions are met. For this study, the binomial distribution function was determined by using the BINOMDIST function in Microsoft Excel.

blank An artificial sample, usually blank water, that is free of the analytes of interest.

equipment blank A blank that is collected in a clean environment, such as inside an office or mobile laboratory, in the same manner as the environmental samples and subjected to all aspects of sample collection except the field environment. The purpose of the equipment blank is to assess contamination of samples by the sample-collection equipment, samplecollection and processing techniques, and equipment cleaning.

extrinsic contamination Contamination of an environmental sample or quality-control sample that originates from a process or source that is external to the medium being sampled and therefore is not representative of the medium being sampled.

field blank A blank that is collected in the field in the same manner as the environmental samples and subjected to all aspects of sample collection. The purpose of the field blank is to assess if equipment or procedures used in the field or laboratory introduced contamination to the samples.

laboratory blank A blank prepared in the laboratory that undergoes all sample preparation and analysis steps used for the environmental samples; this type of blank can be used to determine the laboratory response to a sample that does not contain the analytes of interest or to determine the background response for analytical methods that have a background response.

source-solution blank A blank consisting of freshly opened blank water transferred directly into the bottles under clean conditions and sent directly to a laboratory to confirm that it is free of the analytes of interest.

laboratory reporting level (LRL) A reporting level usually set at a concentration equal to twice the determined LT-MDL. The LRL controls false-negative error; the probability of falsely reporting a nondetection for a sample that contains an analyte at a concentration equal to or greater than the LRL is predicted to be less than or equal to 1 percent. lifetime health advisory level (HAL) The maximum concentration of a constituent at which its presence in drinking water is not expected to cause any adverse carcinogenic effects for a lifetime of exposure. HALs established by the USEPA (HALs-US) are calculated by assuming consumption of $2 \mathrm{~L}$ (2.1 quarts) of water per day over a 70-year lifetime by a 70-kilogram (154-pound) adult and that 20 percent of a person's exposure comes from drinking water.

long-term method detection level (LT-MDL) A detection and reporting level derived from a modification of the USEPA MDL calculation or by determining the second-highestranked blank concentration when there are less than 100 blank samples or the $99^{\text {th }}$ percentile of the blank population when there are 100 or more blank samples. LT-MDL data were collected continuously throughout the year to assess variations in method performance. The LT-MDL controls false-positive error; the probability of falsely reporting a detection for a sample that contains the analyte at a concentration less than the LT-MDL is predicted to be less than or equal to 1 percent.

maximum contaminant level (MCL) A legally-enforceable standard for public-water systems that is designed to protect public health by limiting the levels of contaminants in drinking water. MCLs established by the USEPA (MCL-US) are the minimum standards with which States are required to comply. The CDPH has established MCLs (MCL-CA) for several constituents that are not regulated by the USEPA and has set more stringent benchmarks for some constituents with MCLs-US.

notification level (NL) A health-based standard established by the CDPH (NL-CA) for some of the constituents in drinking water that lack MCLs. If a constituent is detected above its NL-CA, California law requires timely notification of local governing bodies and recommends consumer notification.

reporting level A generic term used by the USGS National Water Quality Laboratory when referring to the "less than" concentration provided when the analyte is not detected or is detected at a concentration below a minimum (censor-limitbased) concentration. Prior to October 2010, the reporting level for inorganics analyzed at the NWQL was the LRL; the reporting level for inorganics starting October 2010 was the LT-MDL.

\section{secondary maximum contaminant level (SMCL) A non-} enforceable standard that applies to constituents that affect the aesthetic qualities of drinking water, such as taste, odor, and color, or technical qualities, such as scaling and staining. SMCLs established by the CDPH (SMCL-CA) are not required to be as stringent as those established by the USEPA and were used in this report as the comparative benchmark for all constituents that have SMCL-CA values. 
Publishing support provided by the U.S. Geological Survey Science Publishing Network, Sacramento, Tacoma, and Raleigh Publishing Service Centers

For more information concerning the research in this report, contact the Director, California Water Science Center

U.S. Geological Survey

6000 J Street, Placer Hall

Sacramento, California 95819

http://ca.water.usgs.gov 
